\title{
Facilities Evaluation Report
}

\author{
P. A. Sloan \\ C. R. Edinborough
}

Published April 1992
Iodaho National Engineering Laboratory EG\&G Idaho, Inc. Idaho Falls, Idaho 83415


Facilities Evaluation Report

EGG-WTD-10143

Prepared by:

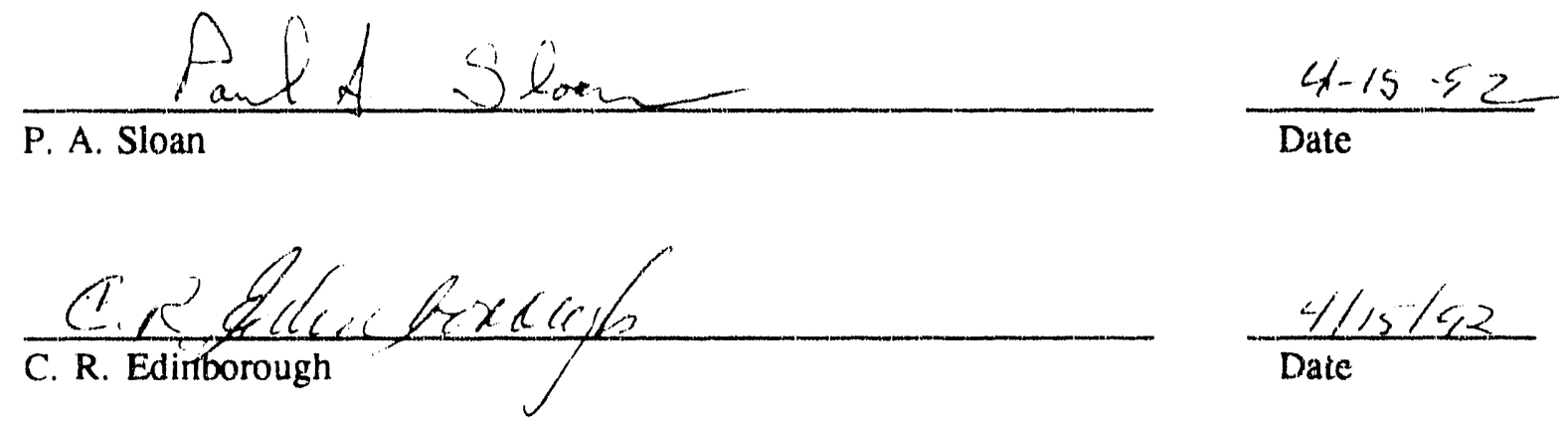

Reviewed by:

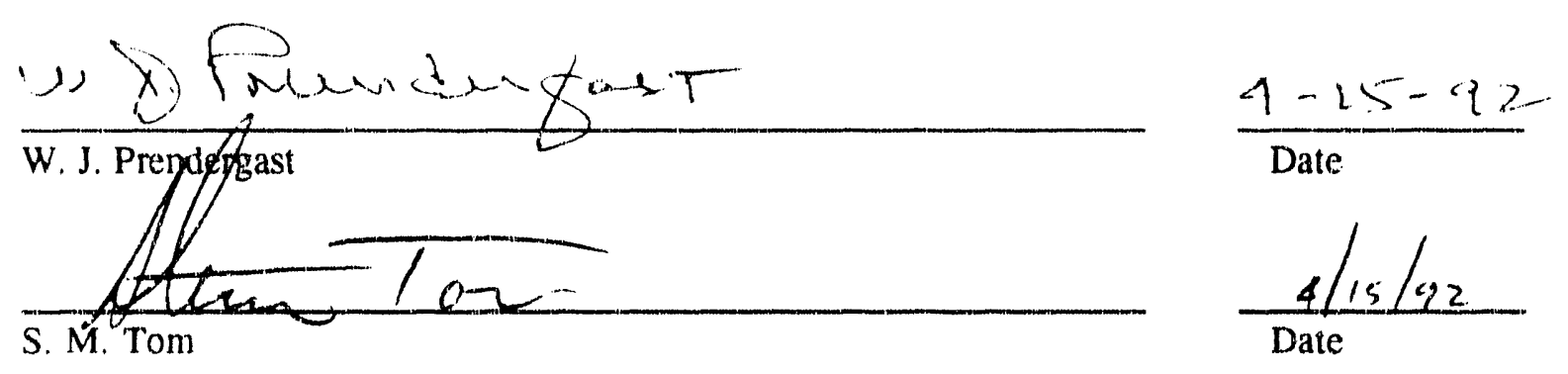

Reviewed and Approved by:

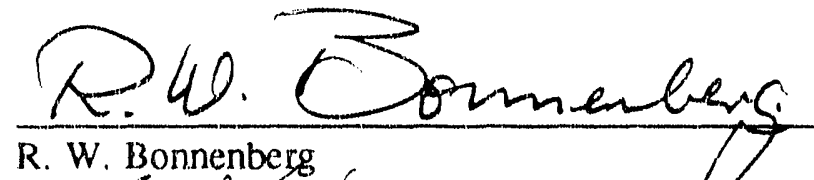

R. W. Bonnenberg

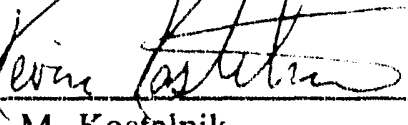

M. Kostelnik

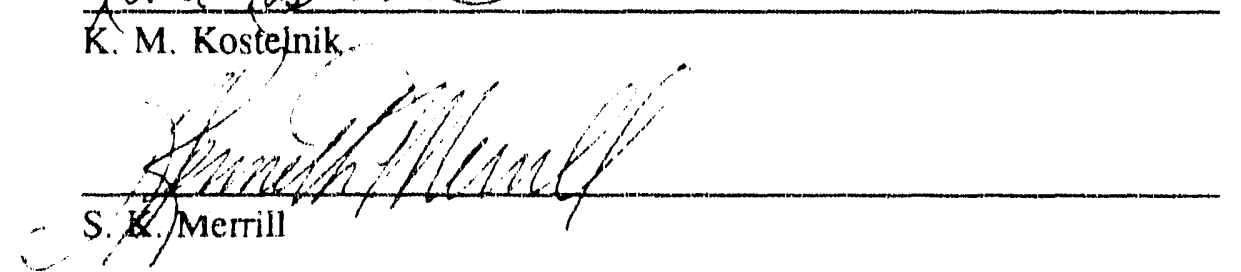

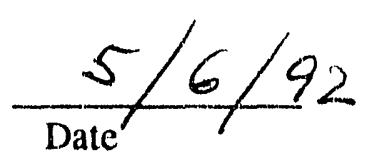
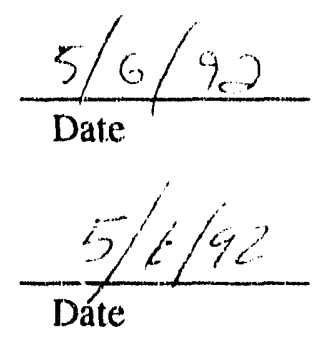


\section{ABSTRACT}

The Buried Waste Integrated Demonstration (BWID) is a program of the Department of Energy (DOE) Office of Technology Development whose mission is to evaluate different new and existing technologies and determine how well they address DOE community waste remediation problems. Twenty-three Technical Task Plans (TTPs) have been identified to support this mission during FY-92; 10 of these have identified some support requirements when demonstrations take place. Section 1 of this report describes the tasks supported by BWID, determines if a technical demonstration is proposed, and if so, identifies the support requirements requested by the TTP Principal Investigators. Section 2 of this report is an evaluation identifying facility characteristics of existing Idaho National Engineering Laboratory (INEL) facilities that may be considered for use in BWID technology demonstration activities. 


\section{SUMMARY}

The Department of Energy (DOE) and its predecessor agencies have operated numerous facilities throughout the United States for research, development, and production in the areas of defense and nuclear energy. Waste generated by these operations is buried or stored at several locations throughout the DOE complex. Much of the waste is mixed (containing both hazardous and radioactive components), making permanent disposal of the waste and remediation of the storage and burial sites more difficult to accomplish within the current regulatory framework.

The Buried Waste Integrated Demonstration (BWID) is a program of the DOE's Office of Technology Development (OTD). The program was developed to identify new and existing technologies which may be used to solve the complex problems of mixed and radioactive waste disposal and remediation. Successful completion of the integrated demonstrations identified under this program will result in their transfer to other DOE sites, other government agencies, private industry, and universities.

BWID has recognized that some facility support will be required for successful demonstration of the integrated technologies. Data in this report provide information describing the facility support requirements defined by the Technical Task Plan (TTP) Principal Investigators, as well as information identifying support characteristics of existing Idaho National Engineering Laborarory (INEL) facilities. The report is organized into two sections which are described as follows.

Section 1 of this report is an evaluation of all existing BWID TTPS to date, and identifies requirements specific to each technology as defined by each TTP Principal Investigator. Twentythree of the FY-92 BWID TTPs are addressed in this section, 10 of which have potential for field demonstration at the INEL. Evaluation data for these 10 TTPs contain detailed information describing the TTP scope, the related technology process/equipment, the technology facility support requirements, the proposed technology demonstration site, and the current schedule for technology demonstration. The remaining 13 TTPs evaluated in this section contain information describing the scope of each TTP and an explanation as to why they require no facility support activity.

Section 2 of this report is an evaluation of existing INEL buildings and services that have the potential for being used in support of BWID technology development and testing. Facility evaluation data were collected during site examinations of various INEL facilities and are presented in this report to reflect an operational perspective of facility capabilities that will support BWID technology demonstrations.

Also included in this report are 'Tables 1 and 2 . Tabie 1 is a technology versus requirements matrix and can be used as a quick reference in determining specific TTP facilities support requirements. Table 2 is a milestone schedule that shows when the demonstrations and, thus, the support requirements are planned to be implemented. Associated with Section 2 are several figures (area maps). The figures are used as visual aids for better understanding facility locations and the appendices provide clarifying information relating to facility conditions.

Information in Section 1 of this report has shown that five of the ten TTP Principal Investigators have requested work space adjacent to their demonstration sites in the form of office space, phones, PCs, and work benches for the calibration, adjustment, and repair of the tect equipment. This required space can be provided either by setting up office trailers ner the 
demonstration sites, or space can be allocated in existing facilities near the demonstration sites. Also identified in this section is the fact that several of the demonstrations will produce contaminated secondary waste. BWID will be expected to provide assistance in the disposal or storage of this waste.

Information contained in the facilities surveys found in Section 2 of this report has identified one common denominator associated with the facilities. All of the existing facilities were constructed during the 1950s and 1960s. Building codes at that time were much less stringent than now, and as a result almost all of the facilities surveyed have some building code problems.

BWID will continually identify additional technologies for potential demonstration at the INEL. Facility requirements for these technologies will be determined. This report will be revised as necessary to accommodate new technologies. 


\section{CONTENTS}

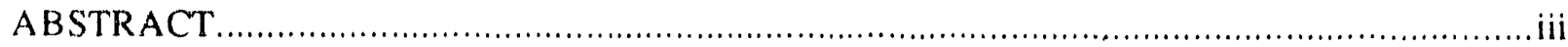

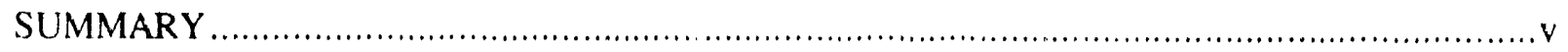

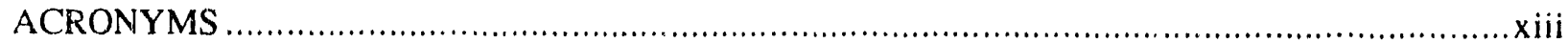

\section{SECTION 1}

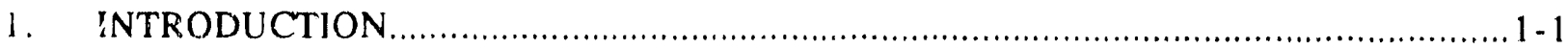

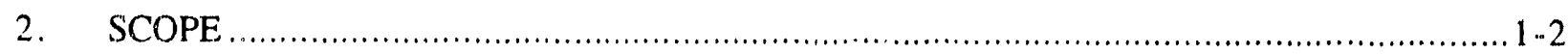

3. TTP EVALUATIONS REQUIRING FACILITY SUPPORT .................................... $1-3$

3.1 TTP IT)121203 Cryogenic Retrieval........................................................... 1 -3

3.1.1 Task Description..................................................................... 1-3

3.1.2 Process/Equipment Description................................................. 1 -3

3.1.3 Process Facility Support Requirements............................................ 1-4

3.1.4 Technology Demonstration Site ...................................................... 1-4

3.1.5 Process Secondary Waste ......................................................... 1 - 4

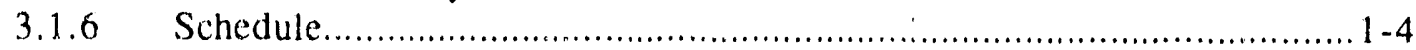

3.2 TPP RI.421212 Monolithic Confinement of RWMC Geologic Media.................... 1-5

3.2.1 Task Description........................................................................... $1-5$

3.2.2 Process/Equipment Description....................................................... 1-5

3.2.3 Process Facility Support Requirements.............................................. 1-5

3.2.4 Technology Demonstration Site....................................................... $1-6$

3.2.5 Process Secondary Waste ............................................................. 1 - 6

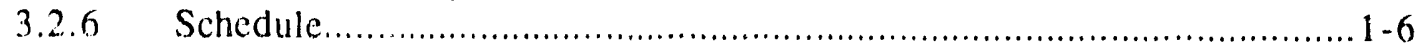

3.3 TTP SR 101201 TRU Waste Treatment Methodology ....................................... 1-7

3.3.1 Task Description........................................................................

3.3.2 Process/Equipment Description....................................................... $1-7$

3.3.3 Process Facility Support Requirements............................................... 1-7

3.3.4 Process Secondary Waste .............................................................. 1 - 7

3.3.5 Schedule .................................................................................

3.4 TTP IDO01201 Non-Intrusive Sensing of Objects......................................... 1 -

3.4.1 Task Description.................................................................... 1-7

3.4.2 Process/Equipment Description .................................................... $1-8$

3.4.3 Process Facility Support Requirements.......................................... 1 1.9

3.4.4 Technology Demonstration Site.............................................. $1-10$ 
3.4.5 Process Secondary Waste ..................................................... $1-10$

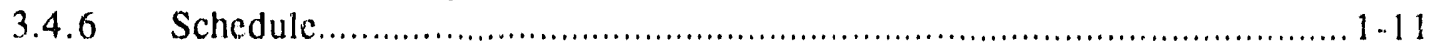

3.5 TTP OR121201 Luminescent Spot Test for Polychlorinated Biphenyls.................... 1-11

3.5.1 Task Description........................................................................... 11

3.5.2 Process/Equipment Description...................................................... 1-12

3.5.3 Process Facility Support Requirements........................................... $1-12$

3.5.4 Technology Demonstration Site.................................................. 1 - 12

3.5.5 Process Secondary Waste ............................................................... 1 - 2

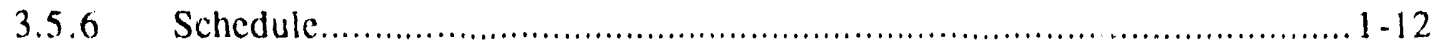

3.6 TTP ID121204 Biological Destruction of Nitrates........................................ $1-13$

3.6.1 Task Description.......................................................................... 13

3. 2 Process/Equipment Description ...................................................... 1-13

30.3 Process Facility Support Requirements............................................. 1-13

3.6.4 Technology Demonstration Site................................................. 1-14

3.6.5 Process Secondary Waste ........................................................ 1 - 14

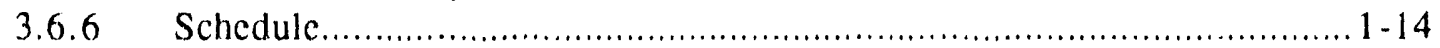

3.7 TTP ID121205 Pad A Treatability Study ................................................. $1-14$

3.7.1 Task Description.......................................................................... 14

3.7.2 Process/Equipment Description................................................... 1 - 14

3.7.3 Process Facility Support Requirements........................................... $1-15$

3.7.4 Technology Demonstration Site.................................................. $1-15$

3.7.5 Process Secondary Waste ............................................................... 1 - 15

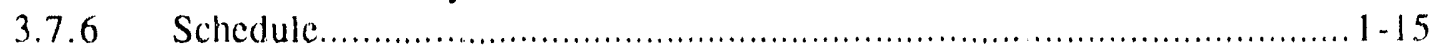

3.8 TTP ID 121213 Field Demonstration of Characterization Technologies.................. 1-15,

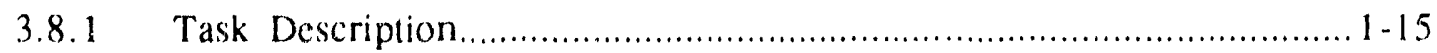

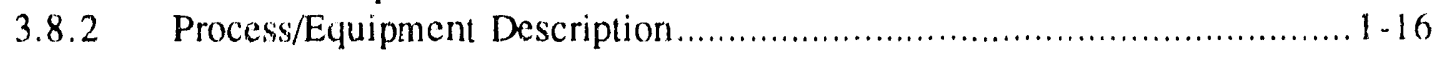

3.8.3 Process Facility Requirements................................................ $1-16$

3.8.4 Technology Demonstration Site.................................................... 1 - 16

3.8.5 Process Secondary Waste ............................................................ 16

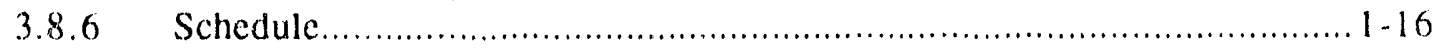

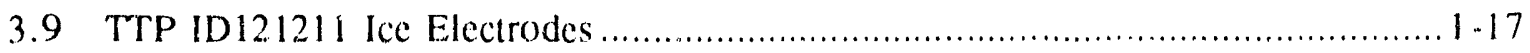

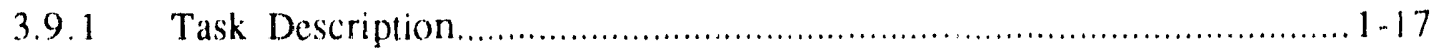

3.9.2 Process/Equipment Description...................................................... 1-17

3.9.3 Process Facility Suppont Requirements........................................... 1-17

3.9.4 Technology Demonstration Site.................................................... 1 - 17

3.9.5 Process Secondary Waste ............................................................. 1 - 17

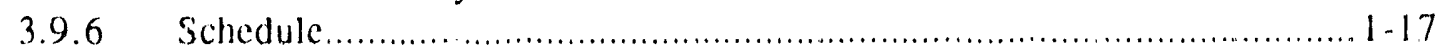


3.10 TTP CH201202 Ultrasonic Process for Groundwater Detoxification....

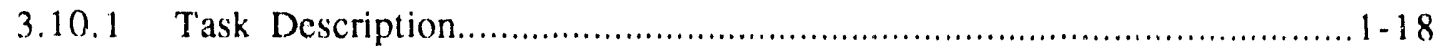

3.10.2 Process/Equipment Description........................................................ 1 - 18

3.10.3 Process Facility Support Requirements.................................................. 1 - 18

3.10.4 Technology Demonstration Site....................................................... 1-19

3.10.5 Process Secondary Waste .............................................................1-19

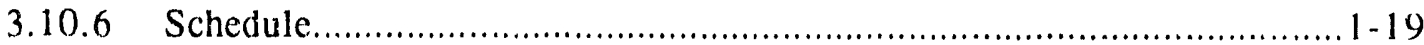

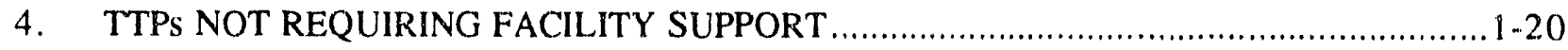

4.1 TTP AL101201 BWID Decision Support .................................................... 1-20

4.1.1 Task Description.......................................................................... 1 -20

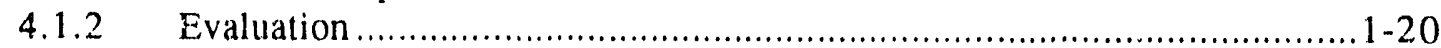

4.2 TTP CH121201 Non-Destructive Evaluation/Non-Destructive Assay (NDE/NDA) Peer Review ................................................................. 1 - 20

4.2.1 Task Description.......................................................................... $1-20$

4.2.2 Evaluation ......................................................................... $1-20$

4.3 TTP RL321207 Public Acceptance and Regulatory Feasibility............................. 1-20

4.3.1 Task Description........................................................................... $1-20$

4.3.2 Evaluation ..................................................................................... 1 - 1

4.4 TTP ID()21204 TRU/Hazardou; Waste Characterization Technologies ................... 1-21

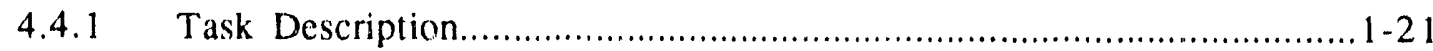

4.4.2 Evaluation .................................................................... 1 -21

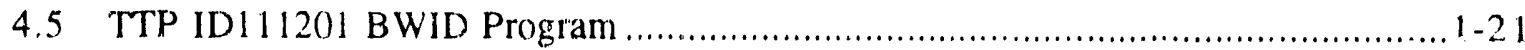

4.5.1 Task Description........................................................................ $1-21$

4.5.2 Evaluation .................................................................................. $1-21$

4.6 TTP IDI11202 In Situ Vitrification (ISV) R\&D SDA/Acid Pit .......................... 1-21

4.6.1 Task Description.................................................................... $1-21$

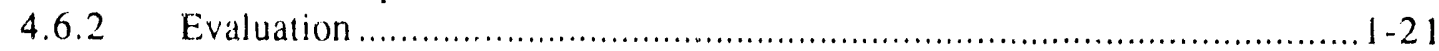

4.7 TTP ID 121202 System Design Study ................................................... 1-22

4.7.! Task Description................................................................. 1-22

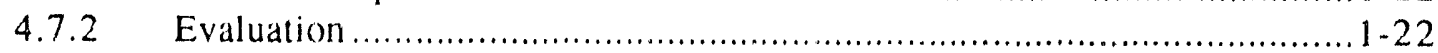


4.8 TTP ID121206 Retrieval Suppont Technologies............................................. 1-22

4.8.1 Task Description...................................................................... 1 -22

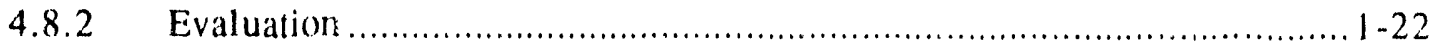

4.9 TTP ID121207 Thermal Processing Methods ................................................. 1-22

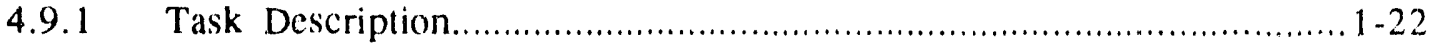

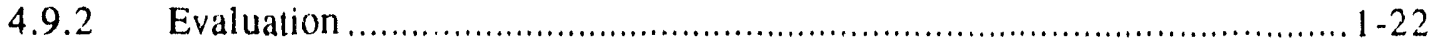

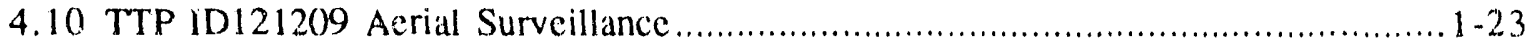

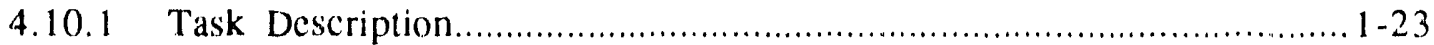

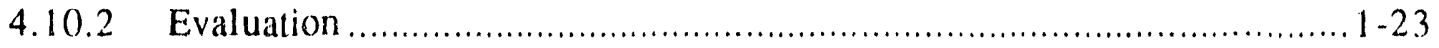

4.11 TTP OR101202 Destruction of PCBs in Mixed Waste ..................................... 1-23

4.11.1 Task Description........................................................................ 1 - 23

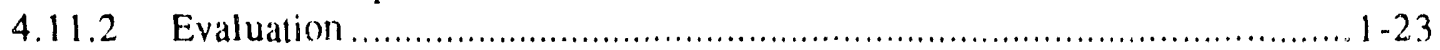

4.12 TTP RL421213 DOE Complex Buried Waste Assessment .................................. 1-23

4.12.1 Task Description......................................................................... 1 - 23

4.12.2 Evaluation ........................................................................ 23

4.13 TTP SR121201 SRL Characterization Technology ..................................1-24

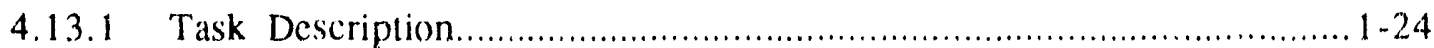

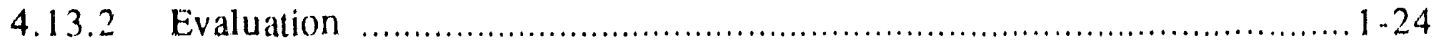

\section{SECTION 2}

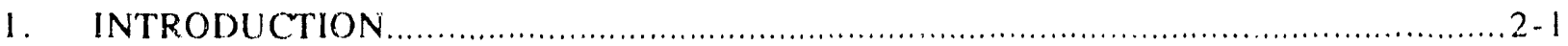

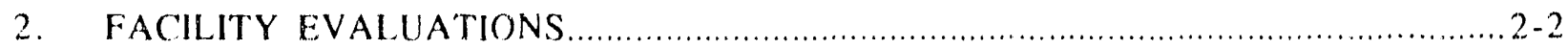

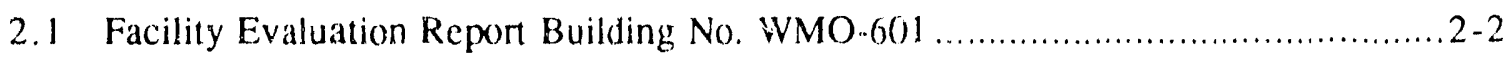

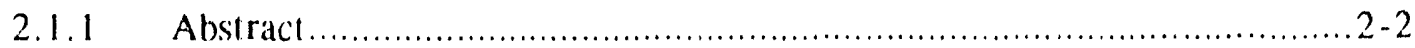

2.1.2 Facility Description ............................................................... 2-2

2.1.3 Operational Evaluation of the Building ...................................... 2-2

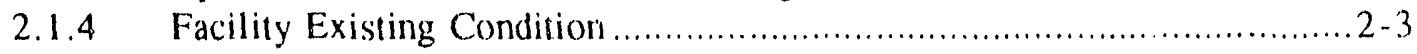

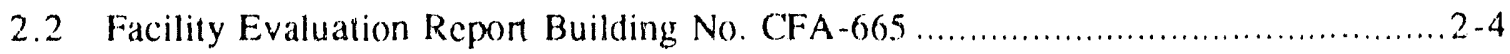

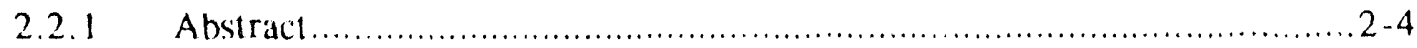

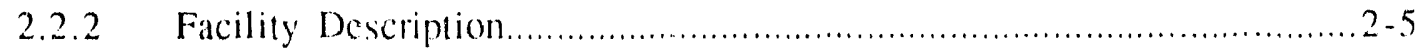

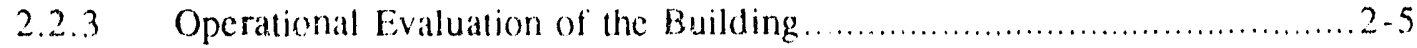

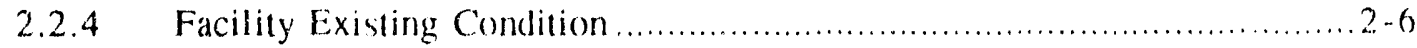


2.3 Facility Evaluation Report Building No. CFA-689

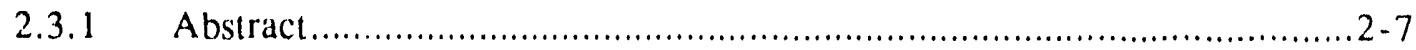

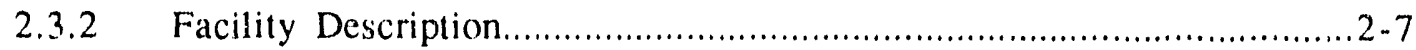

2.3.3 Operational Evaluation of the Building............................................2-7

2.3.4 Facility Existing Condition .......................................................2.9

2.4 Facility Evaluation Report Building No. PBF-612 (WEDF) ...............................2-9

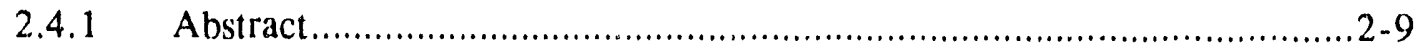

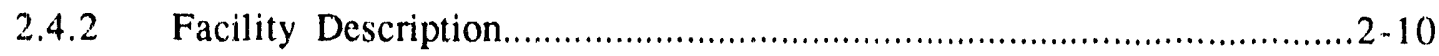

2.4.3 Operational Evaluation of the Building............................................2-10

2.4.4 Facility Existing Condition ...................................................... 2-11

2.5 Facility Evaluation Report Building No. PBF-613 (RMWSF) ..............................2-12

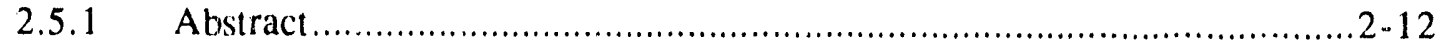

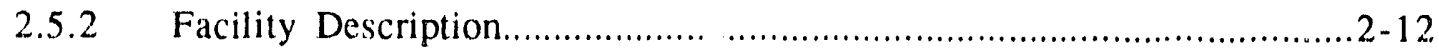

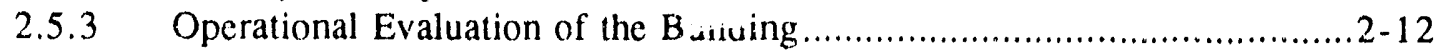

2.5.4 Facility Existing Condition .......................................................2-13

2.6 Facility Evaluation Report Building No. TAN-645,646.................................... $2-14$

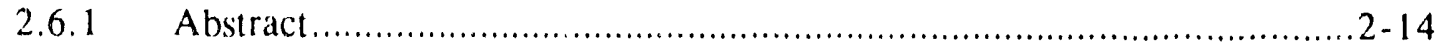

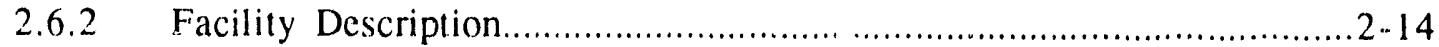

2.6.3 Operational Evaluation of the Building .............................................2-15

2.6.4 Facility Existing Condition .................................................... 2-16

2.7 Facility Evaluation Report Building No. TAN-640, 641 .................................... 2-17

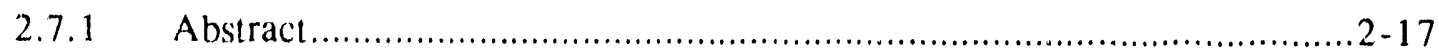

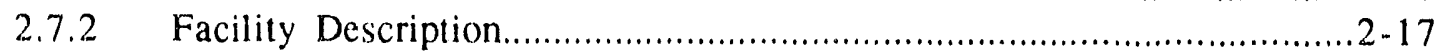

2.7.3 Operational Evaluation of the Building............................................. $2-18$

2.7.4 Facility Existing Condition ................................................... 2-19

2.8 Facility Evaluation Report Building No. TAN.607......................................2-20

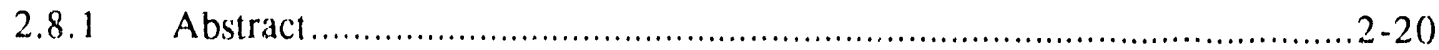

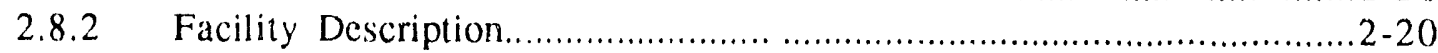

2.8.3 Operational Evaluation of the Building ...........................................2-20

2.8.4 Facility Existing Condition .........................................................2-22

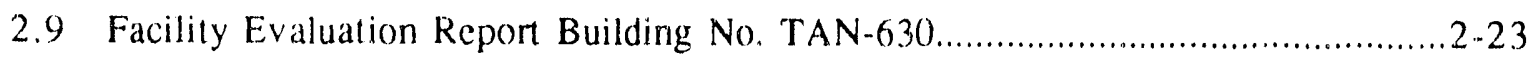

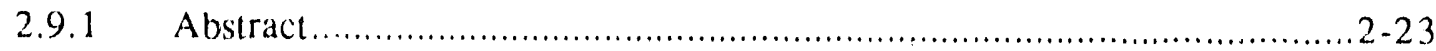

2.9.2 Facility Description..................................................................... 2-23

2.9.3 Operational Evaluation of the Building .........................................2 2-23

2.9.4 Facility Existing Condition .........................................................2.2. 25 


\section{FIGURES}

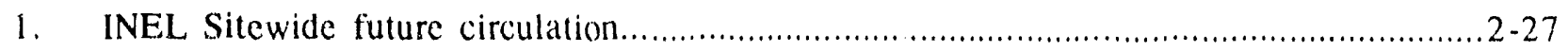

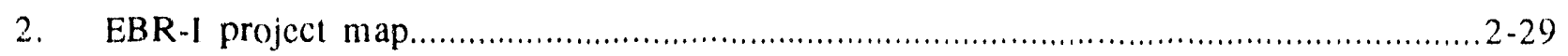

3. Area lighting at the Central Facilities Area ............................................................ $2-31$

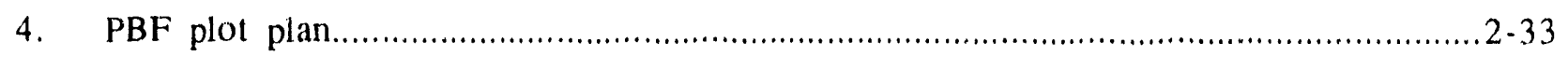

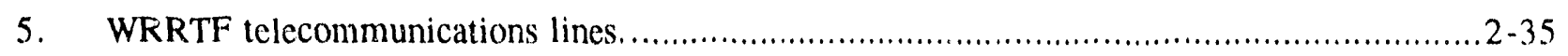

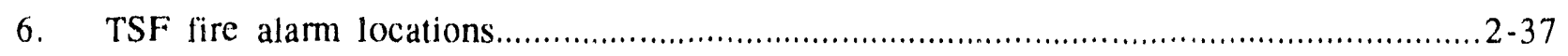

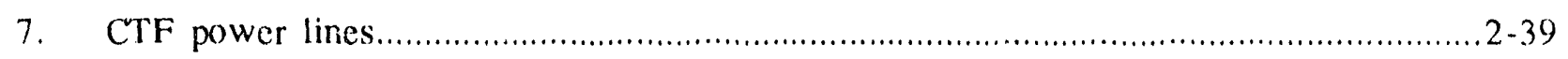

\section{TABLES}

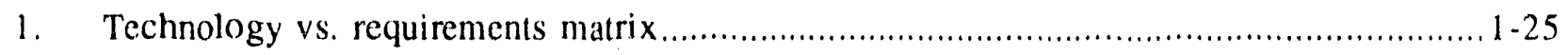

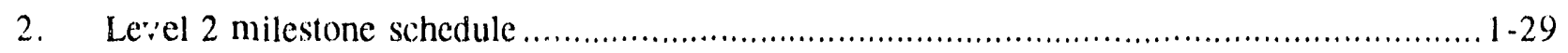




\section{ACRONYMS}

\begin{tabular}{|c|c|}
\hline BMAR & Backlog of Mainteriance and Repair \\
\hline$B \& W$ & Babcock and Wilcox \\
\hline BWID & Buried Waste Integrated Demonstration \\
\hline CFA & Central Facilities Area \\
\hline CFR & Code of Federal Regulations \\
\hline DAVDS & Data Acquisition and Visual Display System \\
\hline DT\&E & Demonstration, Testing, and Evaluation \\
\hline DOE & Depariment of Energy \\
\hline EBR-1 & Experimental Breeder Reactor 1 \\
\hline $\mathrm{EM}$ & Electromagnetics \\
\hline ER & Environmental Restoration \\
\hline FAA & Federal Aviation Administration \\
\hline FMPC & Fernald Materials Processing Center \\
\hline FY & Fiscal Year \\
\hline $\mathrm{GC}$ & Gas Chromatography \\
\hline GTCC & Greater-Than-Class-C \\
\hline $\mathrm{HCF}$ & Hot Cells Facility \\
\hline HEPA & High-Efficiency Particulate Air \\
\hline ID & Integrated Demonstrations \\
\hline IET & Initial Engine Test \\
\hline INEL & Idaho National Engineering Laboratory \\
\hline ISV & In Situ Vitrification \\
\hline LANL & Los Alamos National Laboratory \\
\hline
\end{tabular}


LLNL.

I.LW

L.OFT

LST

$\mathrm{MCC}$

MS

NAK

NDE/NDA

NEC

NEPA

NTS

ORNL

OSHA

OTD

PBF

PCBs

PI

PREPP

PROFS

RCRA

RDDT\&E

RGE

RL/FS

RMWSF

ROD
Lawrence Livermore National Laboratory

low-level waste

Loss Of Fluid Test Facility

Luminescent Spot Test

Motor Control Center

Mass spectrometry

Sodium and Potassium

Non-destructive Evaluation/Non-destructive Assay

National Electric Code

National Environmental Policy Act

Nevada Test Site

Dak Ridge National Laboratory

Occupational Safety and Health Act

Office of Technology Development

Power Burst Facility

Polychlorinated Biphenyls

Principal Investigator

Processing Experimental Pilot n! unt

Professional Ofrice Systems

Resource Conservation and Recovery Act

research and development demonstration testing and evaluation

Rapid Geophysical Surveyor

Remedial investigation/Feasibility Study

Radioactive Mixed Waste Storage Facility

Record of Decision 
RWMC

SAR

SDA

SMC

SNL.

SPERT

SRL

SWP

TAN

TMI

TSF

TTP

VOCs

WEDF

WERF

WMO

WMTO

WRRTF

WSRC

WTDD
Radioactive Waste Management Complex

Safety Analysis Report

Subsurface Disposal Area

Specific Manufacturing Capability

Sandia National Laboratory

Special Power Excursion Reactor Test

Savannah River Laboratory

Safe Work Permit

Test Area North

Three Mile Island

Technical Support Facility

Technical Task Plan

Volatile Organic Cumpounds

Waste Engineering Development Facility

Waste Experimental Reduction Facility

Waste Marragement Operation

Wastc Management TAN Operations

Water Reactor Research Test Facility

Westinghouse Savannah River Complex

Waste Technology Development Department 


\title{
FACILITIES EVALUATION REPORT
}

\author{
Section 1
}

An Evaluation of BWID Technical

Task Plan Facility Support Requirements 


\section{Facilities Evaluation Report}

\section{SECTION 1}

\section{An Evaluation of BWID Technical Task Plan Facility Support Requirements}

\section{INTRODUCTION}

The Buried Waste Integrated Demonstration (BWID) is a program of the Department of Energy (DOE) Office of Technology Development (OTD). Because proven technologies do not exist for the in situ treatment of a broad range of buried waste, nor for the comprehensive treatment of the waste after it has been exhumed, OTD has initiated RWID at the Idaho National Engincering Laboratory (INEL).

The BWID is coordinated for the DOE by the Waste Technology Development Department (WTDD) of EG\&G Idaho, Inc., at the INEL. Although hosted at the INEL, BWID will involve scientists and engineers from throughout the DOE complex, universities, and the private sector to design and develop new technologies for the remediation of buried wastes.

The BWID will address the DOE complex problem of buried waste by focusing initially on waste buried at the INEL. This waste stream is generally representative of most buried waste throughout the DOE complex. BWID will transfer proven technologies to the various DOE complex sites with buried waste problems, as well as 10 other government agencies, private industry, and universities. Data derived from BWID activities will also be available to the international community through proper administrative channels. Industrial, academic. and DOE participation is necessary to ensure multidirectional technology transfer. 


\section{SCOPE}

This Facilitics Evaluation Report divides the BWID FY-92 Technical Task Plans (TTP) identified as of March 16,1992, into two general classifications: those requiring facility support at the INEL and those which do not require support, such as evaluations, feasibility studies, etc. The Principal Investigators (PI) of the TTPs were contacted to deternine if support from BWID would be required, and if so, what support they would require, c.g., an enclosure, utilities, or offices.

The BWID Facilities Management \& Data Management System effort is comprised of several tasks. One of the tasks requires that all BWID technology demonstration TTPs be reviewed for facility and support needs. Other requirements for this task are the evaluation of alternative approaches that may be used to obtain facilities, equipment, and services for each planned technolegy demonstration, and to assist the Principal Investigators for these technologies in resolving problems purtaining to facilities, support, and utilities service.

A Data Management System (DMS) is established to support data collection and retrieval needs for the BWID technology demonstrations. The DMS also provides Network connections, local and wide area (LAN/WAN), and remote locations, to facilitate improved communication between $B W I D$ principle investigators and managers located in various states. 


\section{TTP EVALUATIONS REQUIRING FACILITY SUPPORT 3.1 TTP ID121203 Cryogenic Retrieval}

\subsubsection{Task Description}

This task involves the Cryogenic Retrieval TTP. Of two subtasks, the first is the actual cryogenics retrieval task, and the second is the subtask of designing and constructing a weathershield over a major portion of the RWMC Cold Test Pit. The body of this evaluation will be concerned only with the cryogenic retrieval section of this TTP. The weathershield task is currently on a funding hold. When activities resume, its construction will be under contract and will not require support by the BWID Facility Support/equipment task. The task description for the cryogenic subtask is as follows:

- Cryogenic retrieval demonsirations-work planned for FY-92 (all work for this subtask will be completed in FY-92).

These demonstrations intend to show how well freezing soil and wastes in place, followed by extraction of the frozen waste mass, will perform. Initially, a demonstration is planned for the Cold Test Pit (located near the Radioactive Waste Management Complex), which contains simulated waste forms (no hazardous or radioactive materials are present). If the demonstration is successful in the Cold Test Pit, a decision will be made if further demonstrations are warranted at Pad $\mathrm{A}$ and the TRU-contaminated pits and trenches. No funding for these latter activities is included in this TTP.

\subsubsection{Process/Equipment Description}

The cryogenic retrieval process will be demonstrated by first freezing soil and wastes in-place using cryogenics, followed by extraction of the frozen waste mass using remote retrieval equipment. Plans are to complete initial testing of the process on the Cold Test Pit (located near the RWMC) which contains simulated waste forms (no hazardous or radioactive materials are present).

The equipment used in this process can be divided into three subsystems. First, the control center for the operation is contained in a trailer that is placed separate from the excavation area. The traiiar contains office space and a control center where control and monitoring of excavation activities is accomplished. Second, the gantry building is constructed of a heavy steel framework supporting multiple gantry crane asscmblies with grapples, jacks, and retrieval equipment mounted on them. Several closed.circuit TV cameras are installed in the gantry building to allow personnel to monitor and control retrieval activities from the control center. The control center is equipped with TV monitors, instrumentation, recording devices, and control systems to remotely operate the tools located in the gantry building. The gantry building is covered with a reinforced plastic skin to contain and control dust and potential process contamination. Electronic umbilical cords connect the control center with the gantry building for process control. The third subsystem consists of multiple liquid nitrogen tank trailers and cooling probes. The cooling probes are hollow, made of stainless steel, and are approximately 10 -feet long and $11 / 2$-inches in diameter. Supply lines from the tank trailers feed liquid nitrogen to the probes when soil freezing is desired. 
The process of retrieving waste containing soil begins by first placing cooling probes into the ground. This is done by using a sonic drilling rig to insert the cooling prohes in a 12-ft. $\times 12-\mathrm{ft}$. square grid with a spacing of approximately 1-1/2 $\mathrm{ft}$ between the probes. These probes are then filled with liquid nitrogen causing the waste containing soil to frecze. An excavation pit is dug adjacent to the frozen waste, then the gantry building containing excavation tools (gantry jack, gantry grapple, and retrieval tools) is placed over the frozen waste and adjacent excavation pit. The remote operated ganiry jack is used to push against the cooling probes, causing the waste to break off the edge of the frozen waste area and fall into the excavation pit. Waste in the excavation pit is then retrieved and placed in waste storage boxes using the gantry grapple and retrieval tools. This process is repeated until all of the frozen waste in the square grid is retrieved. Once retrieval is complete, the excavated area is then backfilled with clean soil. A new location is then selected for retrieval and the total process is repeated.

\subsubsection{Process Facllity Support Requirements}

Based upon information received from the TTP Principal Investigator (PI) in the form of a questionnaire and personal conversation, no facility support will be required for this project. The process is fully self-contained in that required office space, equipment, equipment calibration, test materials, utilities, and assembly/calibration/setup space will be supplied by outside contractors as arranged for by the PI. Test scheduiting should preclude any road improvements that would be required due to excessive soil moisture. The test will be conducted outside the RWMC control area; therefore, outside contractors will be able to make any area improvements (leveling and clearing equipment set up area) deemed necessary to support the project without union contract conflicts. Necessary refucling and liquid nitrogen replenishment will also be supported by outside contract.

Some water is required for the operation of the system. Planning indicates that the contractor will truck water to the site as required. It may be possible, but not necessary, for the contractor to fill the water truck at the RWMC.

\subsubsection{Technology Demonstration Site}

The only testing that will be done concerning this project will be pilot-scale testing. This testing will take place at the RWMC Cold Test Pit area on the south side of the SDA control area.

\subsubsection{Process Secondary Waste}

The only secondary waste that this process is expected to generate will be the used stainless steel cooling probes and the noncontaminated simulated waste that has been retrieved and placed in weather proof boxes. It is currently planned to excavate approximately 4,000 cubic fect of simulated waste. Plans are for approximately half of the waste to be left in storage boxes at the test site so that potential tieatability study projects will have access to a source of easily accessed simulated waste. The remainder of the excavated waste will be placed back in the Cold Test Pit and covered with clean fill dirt.

\subsubsection{Schedule}

The BWID schedule (see Table 2) states that pilot testing for this technology will start in June, 1992. Currently all activities supporting the pilot-scale testing of cryogenic retrieval are on schedule; however, approval of National Environmental Policy Act (NEPA) documentation is a point of concern and project efforts are now directed at expediting this approval process. 


\subsection{TPP RL421212 Monolithic Confinement of RWMC Geologic Media}

\subsubsection{Task Description}

The object of this task activity is 10 demonstrate monolithic entombment of the geologic media, fractured, and granulated interbed basalt materials underlying the RWMC. Entombment will ensure hydraulic and geochemical isolation of contaminants below liquid or solid waste disposal structures. Stabilization of contaminants and hydraulic isolation will permit effective long-term r'osure. Diffusion of contaminants out of the monolith and of infiltrating water into the monolith will be eliminated or reduced to less than regulatory limits.

Denonstration of monolith placement will follow equipment and materials specification and te. ${ }^{\prime}$ ing, scaled testing, equipment operational testing, and final treatment demonstration.

\subsubsection{Process/Equipment Description}

The concept of the monolithic containment process is fairly simplistic. Access to the subterranean area to be treated is gained by drilling into it, and then grout consisting of either concrete or polymer fixants is pumped into the area, immobilizing or entonibing the contaminants. Concrete grout is used to seal fractured basaltic layers, and polymer fixant grout is used to treat the interbed layers of soil. The monolith created will immobilize contaminants within it and seal the basaltic and interbed layers from further contamination. The monolith will also prevent contaminants from leaching down to the aquifer from wastes stored in surficial storage pits and trenches above it.

The equipment used in this process can be divided into two subsystems. The first subsystem is a drilling rig that is required for drilling holes and placing well casings in the ground to a depth reaching the proposed remediation area. The second subsystem is a mobile treatment unit consisting of a flatbed truck or trailer with multiple hoppers, mixing equipment, and a grout pump. The hoppers supply the grout pump with either concrete or polymer grout during processing. When treating with concrete grout, a concrete delivery truck can supply a hopper feeding the grout pump. Power for running the equipment on the flatbed is provided by diesel-powered generators and hydraulic pumps. The unit is completely self-contained.

The proposed treatment process to be used at the RWMC will begin by drilling into the basalt layer beneath the Cold Waste Pit. The mobile treatment unit will then be placed next to the well and lines from the discharge of the grout pump will be connected to the well head. Concrete grout will then be pumped into the first layer of basalt until it is sealed. The drill rig will then continue penetration through the basalt and into the interbed area. Polymer grout is then injecter into the interbed soil. The polymers penetrate into the soil and then harden. Once the interbed is sealed, the process may be repeated and grouting of the second layer of basalt would be completed.

\subsubsection{Process Facllity Support Requirements}

All process equipment and materials will be supplied by the contractor. The mobile treatment unit is totally self-contained in that all power for the process is supplied by equipment on the flatbed. 
Plans are to obtain approvals to use existing monitoring holes located in the area for process demonstration. If new holes are required for this demonstration, BWID Facility Support will have to arrange funding for their installation. Incidental tasks that may require BWID Facility Support are to provide spill protection in the fonm of containment dikes and liners for on-board hydraulic and fuel supply tanks associated with the mobile treatment unit, and to provide restroom facilities (Porta-Potty) while the testing is in progress. Facility Support will be required to exhume portions of the monolith for sample purposes, as requested.

\subsubsection{Technology Demonstration Site}

Plans are to complete pilot testing at the Hanford site. Ficld testing will take place at the INEL-RWMC or INEL-TAN.

\subsubsection{Process Secondary Wasto}

Secondary wastes generated by this process are restricted to washdown water that is used to clean the equipment after test completion and the containers the polymer fixants are received in. It is estimated that approximately 6,000 liters of waste water and residue will result in the post-test washdown of the equipment. In similar tests that have been completed at the Hanford Site, washwater was handled the same as contractors handled washwater for standard concrete pouring activitics. Remaining residue and washwater were allowed to run off of the equipment on to the ground where the water evaporated and the residue hardened. Hardened residue could then be left in place or removed and placed in a landfi'l.

Depending on Idaho State requirements, it may be necessary for personnel to collect and containerize the washdown waste effluent and make arrangements for its disposal. Current project planning allocates no funding for the disposal of the waste other than dumping it on the ground. If collection and disposal of the effluent are required, BWID Facility Support will arrange for funding this activity.

There are multiple polymer fixant materials that may be used in this process. Fixants with a polymer base material requiring no catalyst for polymerization are not classified as hazardous. Packaging for the bulk product can be disposed of in sanitary landfills. One of the polymers being considered for this process is a monomer that requires Benzyl Peroxide as a catalyst fo form the polymer fixant. The polymer, after mixing, presents no hazardous waste problems. The empty containers for the catalyst and the monomer may be a problem. Further investigation will have to be completed concerning the disposal of the base material packaging for this polymer. There is a potential for this packaging to be a hazardous secondary waste problem.

\subsubsection{Schedule}

The only scheduled test that pertains to this document is the field-scale test. This test is currently scheduled to be completed in the second quarter of FY 93 with an associated DOE milestone of September 1993.

A closer look at scheduling may te necessary as the current schedule indicates that festing is to be conducted in the January through March time frame which is historically the coldest time of the year. There may be a problem if the equipment is not designed to withstand freesing to subzern temperatures. 


\subsection{TTP SR101201 TRU Waste Treatment Methodology}

\subsubsection{Task Descriptlon}

This task will develop technologies for minimizing and containing airbome contamination during remediation of DOE buried waste sites containing TRU wastes.

\subsubsection{Process/Equipment Description}

Currently this technology is in the development stage and feasibility studies are in progress. A need has been identified in support of buried waste retrieval to develop an enhanced local ventilation system to remove contaminated dust from the environment at a dig site. This system should significantly reduce spread of contamination inside the retrieval containment building. Developers envision a remote-operated local diffusion hood assembly designed to remove dig generated dust at the dig site. The hood would probably be attached to the building ventilation system in some manner.

\subsubsection{Process Facillty Support Requirements}

This process is being developed in support of the buried waste retrieval project and its demonstration will be in conjunction with the buried waste retrieval demonstrations. No facility support requirements have been identified at this time.

\subsubsection{Process Secondary Waste}

The process will be demonstrated, along with the buried waste retrieval demonstrations, on simulated buried waste at the Cold Test Pit. The only secondary waste expected from this process will be dust collected in the filtration system and filters associated with the filtration system.

All waste from field testing this process will be classified as cold waste. The amount of waste is expected to be: small, so disposal in the land fill should not be a problem.

\subsubsection{Schedule}

Plans are to initiate bench-scale testing of the process in October of 1992. Due to the process being associated with the buried waste retrieval demonstration, no date is scheduled for ficld demonstrations at the RWMC.

\subsection{TTP ID001201 Non-Intrusive Sensing of Objects}

\subsubsection{Task Description}

This TTP is divided into three subtasks in support of the BWID program as described below.

Sublask 1--Site characterization and object location using tensor magnetic gradiometer.

The objective of this subtask is to develop an improved system for non-intrusive site characterization through the measurement and interpretation of the magnetic gradient tensor. During FY-92 a field system will be assembled consisting of (a) dual-beam magnetic gradiometer, (b) an 
elementary track position location device, and (c) PC-based software for data acquisition and sample interpretation.

Subtask 2-Three-dimensional site characterization using broadband electromagnetics (EM).

Current broadband EM technologies and interpretation techniques used in mineral exploration will be adapted for application to detection and three-dimensional characterization of shallow targets normally associated with site characterizations.

Subtask 3-Integrated borehole geophysical system for contaminant identification.

This subtask is to adapt and optimize existing borehole logging equipment to detect contaminants in situ, especially fissile elements and elements that respond to neutron activation. In FY-92, a numeric modeling capability will be implemented to predict and verify performance, and physical models that will provide verification and calibration will be designed.

\subsubsection{Process/Equipment Description}

\section{Subtask 1-Tensor Magnetic Gradiometer Survey}

This task has electronic surveillance equipment mounted on a portable platform constructed much like a twe-whecled lawn cart. The equipment is powered by rechargeable batteries and is designed to detect buried magnetic objects. Data are collected and stored on computer disks.

The area to be surveyed is first divided up into grid squares. The equipment is then placed in service and moved along the grid marks while data are being collected. Data are then examined and area grid maps are developed from the data showing location of buried objects within the ?rid area.

\section{Subtask 2-Broadband Electromagnetic Survey}

This task has portable elecironic surveillanec equipment designed to detect subsurface soil conductivity distribution. The equipment is also powered by rechargeable batterics, is hand carried, and data are collected on computer disks.

The same grid marking in task 1 can be used in this task. The equipment is then placed in service by first stratcgically laying sensor cable over the area within the grid marks. Detection equipment is then placed in service and moved along the grid marks while data are being collected. Data are then examined and area grid maps are developed from the data showing imaging of soil and host rock conductivity as a function of map position and depth.

\section{Subtask 3-Integrated Borchole Survey}

This task has equipment mounted on a 1 -ton truck used for well down-hole monitoring. The equipment will characterize contamination in situ by using well holes in the surveyed areas as a means of accessing the contaminants.

The equipment is placed in service by first backing the logging truck up to a monitoring well. Detection equipment is lowered inte the hole and data are collected on computer disks. Datta from the well logging activities can then be digested and characterization information of the area contaminants is produced. 


\subsubsection{Process Facllity Support Requiremerits}

Each subtask PI was contacied and information related to requirements for their respective subtasks was acquired in the form of a questionnaire. Clarifying information concerning requirements was also obtained via telephone conversations with the PIs. Facility support requirements identified by the PIs are as follows:

\section{Subtask 1-Tensor magnetic gradiometer survey}

Survey grids need to be laid out on the RWMC Cold Pit, the Acid Pit, and one other pit within the SDA. Each pit should have a 4-meter grid on a north-south coordinate system with grid points extending beyond the historical pit boundaries by five or more grid intervals. Though not absolutely necessary, elevation of each grid point should be determined with a precision of $\pm 2 \mathrm{~cm}$. Grid corner point locaiions should be marked with non-magnetic semipermanent markers such as aluminum or, brass pins. All other grid points should be marked with 6 -in. (minimum) square woocin $(1$-in. $\times 1$ in.) stakes driven into the ground within 0.5 in. of the ground level. Each stake should be marked with fluorescent paint and should be witnessed with a 1 -in. $\times 2$-in. stake that protrudes 6 in. above ground level.

The PI requests a base map of the RWMC facility as an AUTOCAD (Version 10) file, shewing location of all horizontal and vertical control points. Overlays of the following information is requested: topographic contour map, location and description of surface culture (fences, buildings, underground and overhead utilities, and other objects), survey grid locations, and historical pit boundaries.

When the demonstration is conducted, the PI will need a desk or work bench to recharge equipment batteries. Access to a phone and desk is also required. Occasional access to standard electronic test instruments may be required. Access to a $\mathrm{PC}$ is preferred, but not necessary.

\section{Suitask 2-Broadband Electromagnetic Survey}

Requirements for this subtask are the same as for subtask 1 with the exception of the request for base map information. No request for the base maps was requested by the PI for subtask 2 .

\section{Subtask 3-Integrated Borehole Survey}

This technology will require bore holes, preferably cased, in environments offering opportunities for successful demonstration. These can be located anywhere at the RWMC. Some of the holes need to be clean, and some need to be located within TRU contaminaiion.

Space with a work bench close to an area where the logging truck can be parked will be required if equipment repairs are necessary. In case of equipment failure, the logging cable will be run from the truck into the work bench to complcte repairs. Office space with access to a phone may occasionally be required. 


\subsubsection{Technology Demonstration Site}

\section{Subtask 1-Tensor magnetic gradiometer survey}

Technology field demonstration for this process will be at the RWMC on the Cold Pit, the Acid Pit, and on one other TRU-contaminated pit within the RWMC.

\section{Subtask 2-Broadband Electromagnetic Survey}

Technology field demonstration siting for this process will be the same as for subtask 1 .

\section{Subtask 3-Integrated Borchole Survey}

Siting for field demonstration of this technology can be located anywhere at the RWMC where appropriate bore holes are located.

It should be noted that there may not be e:isting bore holes at the RWAT that are appropriate for testing this technology, and drilling a new hole in one of the TRU pits in time to support the proposed schedule is highly unlikely. There are many clean holes; however, the contaminated holes may be a problem. Environmental Restoration funded characterization work and analyzed samples taken from bore holes around the Pit 9 periphery and various holes within the Acid Pit. Analysis indicates that one hole in the Acid Pit contains minute amounts of Americium contamination measured in the 1-2 pico curie range, and one Pit 9 peripheral hole contains minutc amounts of Plutonium contamination measured in the $2-3$ pico curic range. No other TRU contamination is evident in bore holes at the RWMC. Phase-two sample results for the ER characterization work in the Acid Pit may indicate higher levels of contamination when the results are available. There are no plans for future characterization bore holes being installed in any of the RWMC pits and trenches at this lime.

\subsubsection{Process Secondary Waste}

Subtask 1-Tensor magnetic gradiometer survey

This process utilizes electronic surveying equipment for subsurface detection of waste forms and, therefore, does not produce any secondary wastes. The equipment is not expected to become contaminated as it does not come in contact with the waste. No secondary waste should be created as a result of equipment decontamination.

\section{Subtask 2-Broadband Electromagnetic Survey}

This process is similar to subtask 1 and is not expected to generatle any secondary waste for the same reasons as subtask 1.

\section{Subtask 3--Integrated Borehole Survey}

This process is a down-hole surveillance system used to characterize in situ lissile waste forms. As the holes should be cased, the probe is not expected to come in contact with contaminated wastes; therefore no secondary waste should be created as a result of equipment decontamination. 


\subsubsection{Schedule}

Subtask 1-Tensor magnetic gradiometer survey

The technology field demonstration for this subtask is scheduled to be conducted in FY-94. Plans are to initiate actual demonstration activities in the first two quarters of FY-94.

\section{Subtask 2-Broadband Electromagnetic Survey}

The technology field demonstration for this subtask is scheduled to be conducted in FY-94. Based on conversation with the PI, his equipment will be ready by the third quarter of FY-92, and he would like to initiate testing in the third or fourth quarter of FY-92.

Subtask 3-Integrated Borchole Survey

The technology field demonstration for this subtask is scheduled to be conducted in April 1994. Based on conversation with the PI, his equipment will be ready by the third quarter of FY-92, and he would like to initiate testing in the third or fourth quarter of FY-92.

\subsection{TTP OR121201 Luminescent Spot Test for Polychlorinated Biphenyls (PCBs)}

\subsubsection{Task Description}

This TTP will evaluate for field use of a new Luminescent Spot Test (LST) technology that was developed at Oak Ridge National Laboratory for the U.S. Environmental Protection Agency used in the screening of polychlorinated biphenyls (PCBs) in a complex environment. This task is divided into three subtasks for organizational purposes. The body of this evaluation will be concerned only with the third subtask as it is the only subtask that will require facility support interface. A task description of all subtask activities will be included in this section as reference to the total project scope. Subtask descriptions are as follows:

Subtask 1-This subtask will evaluate a rapid and practical LST designed to screen PCBs in environmental samples without requiring time consuming laboratory sample extraction and/or chromatographic procedures. This task will also evaluate the effectiveness of various substrate treatments to increase the sensitivity of PCB detection, and to develop and cvaluate methods for quantitative determination of total chlorine content of PCB samples.

Subtask 2-This subtask will develop and fabricate a portable instrument with practical procedures for field applications. The instrument will be battery powered, rugged, and easy to handle with adequate sensitivity for chlorine content determination of complex mixtures of PCBs.

Subtask 3-This subtask will develop specific applications for the field evaluation of the monitoring and remediation activities of PCBs at various DOE sites. This subtask will also pursue technology transfer activities concerning this technology. 


\subsubsection{Process/Equipment Description}

The equipment will be in the form of a rugged. portable instrument that is hand held, baltery powered. and easy to handle.

Preliminary expectation is that the sample process will start by taking a sample specimen and liquefying it with a small amount of solvent. A chenical reagent that fluoresees in the presence of PCBs is then added to the liquified sample. Approximately two drops of the sample will be placed on filter paper and the detector is then used to read the sample and determine PCB contaminant levels.

\subsubsection{Process Facllity Support Requlrements}

The personnel involved with this technolngy will require Facility Support to provide PCB. contaminated samples for analysis and assistance in field sampling during the technology demonstration. Their equipment is portable and requires no power or cooling media. A laboratory bench and work space will be required for initial equipment set-up. No other requirements have been identified by the project Pl.

\subsubsection{Technology Demonstration Site}

No information is available al this time as to where field demonstration will take place. The equipment is still in the development stage. Once the technology has been proven to screen PCBs, decisions on further testing will te made.

The RWMC characterization work to date has not shown PCBs as being a problem there. There are, however. other areas of the site that have minor amounts of contamination. A telephone conversation with Mr. Ted Evans, fomer manager of site PCB cleanup, revealed that there is a site twhind the Test Area North (TAN)-650 facility containing levels of PCBs greater than 25 ppm and possibly as high as $2(x)$ ppm. There are no currem plans to clean this site up. If these concentrations are determined viable by the Pl as a lest medium, this area may be a possible test site.

\subsubsection{Process Secondary Waste}

Wastes produced by this proces will be the soil samples themselves, as well as small amounts of chemical solvents (ethanol) ued in preparing the samples. The Pl specifies using standard disposal procedures for waste disposal.

Facilig suppon will hate to hardle waste disposal at the INEL.

\subsubsection{Schedule}

Latwitutery testing will be completed at ORNL. This tosting should be complete by March 1993. Field keving is scheduled on commence shottly after lab testing is complete. Field tosting is scheduled to the completed by Marsh 1994 


\subsection{TTP ID i21204 Biological Destruction of Nitrates}

\subsubsection{Task Description}

This task is divided into two basic subtasks based on work completed in FY-92 and FY-93. Task descriptions area as follows:

FY-92 Subtask.

This subtask begins by initiating review of the existing site/waste characterization data relative to the potential effects the existing contaminants and was!c conditions may have on a microbial denitrification process. Laboratory space will be acquired at the site and permitting related to this treatability study will be obtained. Testing will commence on various bacterial cultures to determine there applicability to waste forms indicated by the characterization wr rk. Once sufficient characterization and resultant testing of cultures is complete, design and construction of a laboratoryscale bioreactor can be completed, and remediation experimentation on site samples can proceed.

FY-93 Subtask.

This subtask will be to design a demonstration system based on laboratory test results, and assemble it at the test site. Field demonstrations will begin in mid FY-93 and be completed in FY-94.

\subsubsection{Process/Equlpment Descriptlon}

The system will probably consist of a simple lined impoundment in the form of a large metal or plastic tank in which conditions are optimized for the activity of denitrifying bacteria. Nitratecontaminated soil can then be placed in the impoundment and saturated with water containing the required levels of organic matter. The soil is turned periodicaliy to ensure uniform bacteria growth and contaminant degradation. This is sometimes called anacrobic composting.

Where radionuclide co-contamination exists, the impounciment is used for soil washing. Water is circulated through buried pipes and around an external loop that contains a fluidized be 1 denitrifying bioreactor. Organic substrate is then injected just upstream of the bioreactor. This method takes advantage of bioabsorption of radionuclides by the bacteria. In some cases it may allow complete remediation of the soil. Equipment will consist of the tanks mentioned above, along with pumps, filters, and evaporators which are all standard equipment.

\subsubsection{Process Facillty Support Requirements}

Nitrate salt waste from Pad A will be required to sl'pport the lab experiments for this technology. Laboratory experiments will be completed at the INEL Research Complex (IRC) facility, and bench-scale experiments will be conducted al TRA. Pad A waste material will be required for these tests.

Space at the RWMC will be required for field demonstration. An office for two people and a phone with access to a fax machine is required. Process enclosure may require high bay space (approximately $2,000 \mathrm{ft}^{2}$ ) or possibly an enclosure constructed at the demonstration area adjacent to Pad A. Either will require climate control. Help may also be required in setting up the process equipment (power/water/area lighting/berms). 
Personnel with contamination control expertise will be required to support design activities relating to the development of the bench and field test equipment for this TTP.

\subsubsection{Technology Demonstration Site}

Laboratory experiments for initial determination of demonstration feasibility will be conducted at the IRC. Space will be requested from the TRA area to allow for the conduct of benchscale testing of this process. It is intended to conduct actual field demonstration of the process at the RWMC in a location adjacent to Pad $A$.

\subsubsection{Process Secondary Waste}

Wastes are in the form of solids coning from the evaporators. One solid waste stream will be the depleted biomass that also will contain any radionuclide contaminants coming from the reactor. The other waste stream will be nonhazardous salts resulting from the breakdown of the nitrates. These solids will be collected from the evaporators. These wastes will be collected and disposed of using existing best practice for disposal of low-level and nonhazardous solid wastes.

Facility Support help may be required in the disposal process.

\subsubsection{Schedule}

Current scheduling indicates that lab-scale testing will be conducted and completed in FY.-92. Bench-scale testing is to be conducted and completed during FY-93 time period, and the field-ricale demonstration should be conducted in FY-94.

Bench-and field-scale testing schedules may be modified depending on the results of the laibsciale test results.

\subsection{TTP ID121205 Pad A Treatability Study}

\subsubsection{Task Description}

This TTP will investigate, evaluate, demonstrate, and determine the most appropriate waste remediation method(s) appropriate for the remediation of Pad A. The TrTP will also aid in scoping of the remedial investigation/leasibility study (RI/FS), the development of the Record Of Decision (ROD), and the full-scale remediation of the Pad A site.

The ex situ vitrification technology has been selected by this TTP as a result of the evaluation process described above. It has been determined that the scope of this TTP will be limited to the completion of laboratory-scale testing and demonstration of ex situ vitrification to support the RI/FS scoping activities, as well as the development of the ROD.

\subsubsection{Process/Equipment Description}

The process involves the mixing the nitrate salt waste with soil (4) waste to $60 \%$ soil) and melting the mixlure in a cold cap joule heating syotem. This will produce a glass product that is classificel and disposed of as low-level waste. 


\subsubsection{Process racillty Support Requlrements}

There will be no field demonstration activities associated with this TTP. All testing will be done by a vendor at the vendor's facility. No support from BWID Facility Support will be required because of this arrangement.

\subsubsection{Technology Demonstration Site} facility.

As mentioned in Section 4.7.3, the lab-scale demonstration will be conducted at the vendor's

\subsubsection{Process Secondary Waste}

No secondary waste will be produced at the RWMC. BWID Facility Support may have to accommodate final disposition of secondary waste generated at the vendor's facility.

\subsubsection{Schedule}

Demonstration activities in the form of lab-scale testing at the vendor's facility will commence in May 1992, and be completed by the end of September 1992.

\subsection{TTP ID121213 Field Demonstration of Characterization Technologies}

\subsubsection{Task Description}

This TTP will provide for modifications and field demonstrations of technologies demonstrated by other Integrated Demonstrations and Integrated Programs, as well as the identification of new technologies for BWID. These characierization technology demonstrations will provide additional data, fill technological gaps, and enhance retrieval and support remediation efforts.

The TTP consists of four subtasks. Task 1 is the development of a Rapid Geophysical Surveyor (RGS) to collect geophysical data required to locate the boundaries of trenches and pits. A field demonstration is planned in FY-92 to gather data and provide an accurate comparison with current characterization methods. Task 2 is the development of a magnetic anomaly analyzer (algorithm) to interpret magnetic data by comparing measured magnetic anomalies with calculated anorialies for specific buried objects. The location of specific buried objects (e.g., 55-gallon drums or underground storage tanks) based on historic records could be modeled using the aigorithm and then verified for accuracy. Task 3 is a feasihility demonstration of advanced radar for imaging and chiaderizing buried wasic. The demonstration would consist of integrating advanced inverse scattering and other imaging algorithms, in combination with advanced sensor (electromagnetic wave, acoustic wave, and elastic wave tomography) and data acquisition technologies. The results of the combined approach will result in images that are quantitative, corrected for refraction and diffraction, use polarization components of the probing and scaltered fields, and provide improved computational speed and accuracy. The method will improve the ability to distinguish between metallic and non-metallic materials and improve the ability to determine the extent of leakage or migration of uncontained waste or lcaking waste containers. Task 4 consists of the development of an integrated sensor package to characterize hazards at the dig face during retrieval and clean-up 
operations. The benefit of this characterization effort is to accurately and safely identify hazards so that preventative measures can be taken and risks can be reduced.

\subsubsection{Process/Equipment Descriptlon}

A Rapid Geophysical Surveyor will be constructed, which will inclucic four cesium full-view magnetometers mounted on a platform equipped with a distance measuring whecl. A field survey of the Rocky Flats pits and trenches part of the SDA will be performed, and the data collected will be compared with data obtained from current characterization methods, and used to locate the boundaries of the pits and trenches.

An Anomaly Signature Model algorithm will be completed by the Colorado School of Mines to calculate the magnetic anomaly that is caused by a buried metallic object.

An Imaging Demonstration will be completed by the University of Utah and Techniscan in three stages: (1) theoretical validation and algorithm demonstration using a $10 \mathrm{GHz}$ scanner and 1/10-scale models of buried waste, (2) construction of a 0.1-1 GHz mechanical scanner and testing on objects buried in large boxes, and (3) construction of a scanner to scan objects buried in a test pit. The results of this work will be applied to the design and construction of fast, portable, on-line systems for field testing and final application.

Development of a Safe Step Characterization System, which will consist of a review of geophysical, radiological, and chemical sensors currently available or under development, can be integrated into one sensor package. Plans will be established to integrate the sensors into one package to be demonstrated at the Cold Test Pit.

\subsubsection{Process Facillty Requirements}

ISupport requirements have not been identified by the PI yet; we expect requirements to be defined in time for inclusion in t: : final report.!

\subsubsection{Technology Demonstration Site}

The first subtask, RGS, will be performed at the TRU-contaminated pits and trenches area of the SDA. Subtask 2 has no location requirements. Subtasks 3 and 4 can be demonstrated at the Cold Test Pit.

\subsubsection{Process Secondary Waste}

This demonstration utilizes electronic surveying equipment for subsurface detection of waste forms and, therefore, does not produce any secondary wastes. Sublask 3 will have a scale-model demonstration perfonned on boxes filled with simulated waste which can be disposed in the landfill.

\subsubsection{Schedule}

Subtask 1, RGS, is planned 10 be completed in FY-92: subtask 2, the Anomaly Signature Model, is scheduled for completion at the end of FY-92; sublask 3, the Imaging Demonstration, phase 1 , is scheduled for completion at the end of FY-92, and phase 2 is scheduled for completion in the third quarter of FY.93; subtask 4. Safe Step Characterization System, is scheduled for completion at the end of FY-92. 


\subsection{TTP ID121211 Ice Electrodes}

\subsubsection{Task Description}

This task will investigate the feasibility of using an "Ice Electrode" to recover metals from waste streams (solutions) and to combine this technology with Isotron Corporation's ElectrosorbTM system (a polymeric electrode which reduces the hydrogen overpotential) and evaluate the combined effects of both. if these technologies prove effective, they will be further tested to determine their ability to remove heavy metals from soil. Once the technology is proven, the design will be developed and the technology will be demonstrated. The ultimate goal is to develop the Ice Electrode for application to DOE's Environmental Restoration and Waste Operations programs.

\subsubsection{Process/Equipment Descrirtion}

The Ice Electrode is an electrode designed such that a thin sheath of ice can be sustained on its surface. It has been shown that metals can be deposited on the surface of the ice in an clectrochemical cell. This allows easy recovery of the metal by simply allowing the ice to melt. Isotron has developed a polymeric electrode which reduces the hydrogen overpotential. They have been developing this technology for the removal of heavy metals from liquids and soils. It is hoped that the combination of these two technologies will have a synergistic effect in the recovery of metals from contaminated liquids and soils.

The combination of these technologies is in the research and development stage and, as a result, there is no pilot or field test equipment designed or developed yet.

\subsubsection{Process Facllity Support Requirements}

No facility support requirements have been identified by the Principal Investigator for this project.

\subsubsection{Technology Demonstration Site}

Initial demonstration of the technology is expected to be a collaborative effort between EG\&G Idaho and Isotron Corporation. The demoustration site will be in the laboratory.

No site has been identified by the Principal Investigator for field demonstration of the technologies.

\subsubsection{Process Secondary Waste}

The technology is still in the development stage and no secondary waste has been identified by the Principal Investigator.

\subsubsection{Schedule}

Current scheduling states that initial efforts conceming technology proof of concept and collaborative work to combine the technologies will take place in FY-92. A letter report summarizing the findings will be completed in October 1992. Investigation into the technology's applicability 
towards treatment of contaminated soils, development of a scalc-up system for processing, and initial testing of the scale-up system in the lab will take place in FY-93. Plans are to complete field testing sometime during FY-94.

\subsection{TTP CH201202 Ultrasonic Process for Groundwater Detoxification}

\subsubsection{Task Description}

This task is to develop an innovative ultrasonic process for effective destruction of chlorinated organics and other Resource Conservation and Recovery Act (RCRA) components in soil and groundwater. Feasibility of this technology has been demonstrated in small batch tests in the laboratory. The task has three main thrusts: (a) laboratory rescarch to develop an improved understanding of the process kinetics and to identify novel process concepts, (b) process development to systematically acquire engineering data for scalc-up efforts, and (c) technical support to prepare technical reports, to establish cooperative research and development agreements, and to apply for the appropriate permits.

\subsubsection{Process/Equipment Description}

The process essentially involves mixing the contaminated soils with water to make a slurry, pump the slurry through an ultrasonic reactor to break down the chlorinated organics, and separate the cleaned soil and water for disposal.

The system will require the contaminated soils to be removed from the contamination site and placed in a crusher/screen system for sizing prior to being mixed in to a slurry. After sizing, the soil is fed into a mixer where it is mixed into a slurry with clean water. The slurry is then pumped into an ultrasonic reactor where the chlorinated organics are broken down and removed from the slurry. The cleaned slurry then is pumped to a holding tank for analysis. If not completely clean, it can be recycled through the ultrasonic reacis. When determined to be clean, the slurry is then pumped to a settling tank where the water is removed from the soil and recycled into making new slurry. The soil is moved to a dewatering system where residual water in the soil is removed for recycling, and the cleaned soil is disposed.

Contaminated water is expected to be also removed from the contamination site and pumped direclly to the mixing tank. The water will then be pumped into the ultrasonic reactor where the chlorinated organics are broken down and removed from it. Water in the holding tank can then be disposed of once it is determined clean, or recycled until it is clean and then disposed.

At this time the need for an off-gas system has not been determined.

\subsubsection{Process Facility Support Requlrements}

Pilot-scale and field demonstrations for this process will require a source of soil contaminated *ith chlorinated organics. This process is being developed at Argonne National Laboratory in Ciitcago, so shipment of these materials to that facility will be required. If no contaminated materials are availabie at the INEL, arrangements by Facility Support may be required to accommodate their needs. 
It is expected that the field-scale unit will require approximately 1 megawatt of power, a place for equipment se' up and demonstration, office space with access to a phone, and a contaminated soil supply. There are several DOE facilities that meet these requirements. If the process requirements are better met at another facility. Facility Support may be required to assist in making the proper arrangements. If the process is demonstrated at the INEL, BWID Facility Support will help coordinate required facilities to support the demonstration activitics.

\subsubsection{Technology Demonstration Site}

Laboratory and pilot-scale demonstration of this technology will take place at Argonne National Laboratory in Chicago.

A field demonstration site for this activity has not been selected at this time.

\subsubsection{Process Secondary Waste}

Assuming no other contamination than chlorinated organics and other RCRA components in soil and groundwater, no secondary waste is expected.

If the wastes processed by this technology have contamination other than that listed above, the process product (dry soil) may include residual contamination and require special consideration for disposal. When offgas processing requirements have been identified, contaminated filters may also become a secondary waste.

\subsubsection{Schedule}

The lab-scale continuous flow unit is scheduled to be developed and the process tested in FY92. A pilot-scale system is to be developed and tested in FY-93. A field demonstration unit will be developed and tested in FY-94. Field demonstration is scheduled to start in April 1994, and is to be complete in October 1994. 


\section{TTPS NOT REQUIRING FACILITY SUPPORT}

\subsection{TTP AL101201 BWID Decision Support}

\subsubsection{Task Description}

This TTP will provide funding for personnel at Los Alamos National Laboratory (LANL) to support BWID in technology selection and in conducting a strategic study of major buried waste altematives. During FY-93 and FY-94 support will continue in the area of selection support and also in detailed cost effectiveness analysis of demonstration, testing, and evaluation (DT\&E) technologies at BWID that is based on the methodology developed with research and development (R\&D) funding under Activity Data Sheet number AL101201. Reports of the results will be disseminated as appropriate. The specific technologies to be analyzed in depth will be chosen through discussions with OTD and BWID managers.

\subsubsection{Evaluation}

This TTP completes evaluation reports concerning cost effectiveness related to various remediation technologies. There is no direct interface required by Facilities Support to support this TTP.

\subsection{TTP CH121201 Non-Destructive Evaluation/Non-Destructive Assay (NDE/NDA) Peer Review}

\subsubsection{Task Description}

This TTP provides funding for the independent review of the Technology Status Reports prepared for DOE Non-Destructive Evaluation/Non-Destructive Assay (NDE/NDA) projects. The peer review reports will be used to aid in determining how the funding held in BWID for lechnology development tasks in this subject area will be distributed to candidate projects.

\subsubsection{Evaluation}

This TTP supports peer review of technology status reports concerning how funding from BWID will be distributed to various remediation technologies. There is no direct interface reguired by Facilities Support to suppont this TTP.

\subsection{TTP RL321207 Public Acceptance and Regulatory Feasibility}

\subsubsection{Task Description}

This task supports BWID by evaluating and enhancing the public acceptability and regulatory feasibility of the systems and technologies to be demonstrated. This task evaluates whether the public will aceept the use of specific technologies to remediate hazardous and nuclear waste, and whether the technologies can meet regulatory criteria necessary for development. The knowledge gained throughoul these activities may be used for program modifications to enhance acceptance. 


\subsubsection{Evaluation}

Work completed in this TTP is an evaluation study of proposed remediation technologies from the standpoint of public acceptance and compliance to regulatory requirements. There is no direct interface required by Facilities Support to support this TTP.

\subsection{TTP ID021204 TRU/Hazardous Waste Characterization Technologies}

\subsubsection{Task Description}

This TTP is set up as a document listing five different characterization technologies as being on hold for further review. Review will determine future funding and activity concerning the technologies.

\subsubsection{Evaluation}

This TTP is a holding document for five different characterization technologies. There is no direct interface required by Facilities Support to support this TTP.

\subsection{TTP ID111201 BWID Program}

\subsubsection{Task Description}

This BWID Program Support TTP involves funding multiple subtasks. These tasks include: IDC Support, ID Support, Demonstration Strategy, Test Planning, Regulatory Documentation, Compliance Documentation, Operations Support, Facilities/Equipment Support, and Technology Integration/Transfer.

\subsubsection{Evaluation}

This TTP is an administrative document providing funding for BWID Program Support. There is no direct interface required by Facilities Support to support this TTP.

\subsection{TTP ID111202 In Situ Vitrification (ISV) R\&D SDA/Acid Pit}

\subsubsection{Task Description}

The purpose of this TTP is to provide site-specilic applied research and development efforts in support of the complementary ISV DT\&E program efforts on the SDA Acid Pit.

\subsubsection{Evaluation}

The work completed by this TTP will be accomplished in an existing facility at the INEL. All facility activities are funded and controlled by this TTP. There is no direct interface required by Facilities Support to support this TTP. 


\subsection{TTP ID1:12.02 System Design Study}

\subsubsection{Task Description}

Work completed by this TTP will identify and evaluate comprehensive systems for the remediation of INEL TRU-contaminated buried wastes. The study will serve two purposes, (a) it will guide the selection and technical justification for the development and demonstration of technologies within the scope of the BWID program and (b) it will identify INEL buried waste technology gaps in terms of measurable performance data which require Research and Development. Demonstration, Testing, and Evaluation (RDDT\&E).

\subsubsection{Evaluation}

This TTP provides support for innovative technology design studies to determine which are viable for potential use in waste remediation. There is no direct interlace required by Facilities Support to support this TTP.

\subsection{TTP ID121206 Retrieval Support Technologies}

\subsubsection{Task Description}

This TTP is set up as a document listing four different retrieval support and contamination control technologies as being on hold for further review. Review will determine future funding and activity concerning the technologies.

\subsubsection{Evaluation}

This TTP is a holding document for four different retrieval support and contamination control technologies. There is no direct interface required by Facilities Support 10 support this TTP.

\subsection{TTP ID121207 Thermal Processing Methods}

\subsubsection{Task Description}

This TTP is set up as a document listing nine different thermal processing technologies as being on hold for further review. Review will determine future funding and activity concerning the technologies.

\subsubsection{Evaluation}

This TTP is a holding document for nine different thermal processing technologies. There is no direct interface required by Facilities Support to support this TTP. 


\subsection{TTP ID121209 Aerial Surveillance}

\subsubsection{Task Description}

The objective of the Acrial Surveillance \& Analysis Demonstration at the Radioactive Waste Management Complex (RWMC) project is to provide testing and support of airborne geophysical sensors fo- the identification of subsurface soil characteristics, locations of buried waste, and previously expended ordnance on the INEL.

\subsubsection{Evaluation}

Work on this TTP is essentially complete. No more field work (flyovers) is required. There is no direct intcrface required by Facilities Support to support this TTP.

\subsection{TTP OR101202 Destruction of PCBs in Mixed Waste}

\subsubsection{Task Description}

This TTP will support work done at Oak Ridge National Laboratory (ORNL) to determine if base-catalyzed destruction of chlorinated organics is an appropriate technology for treatment of DOE mixed wastes.

\subsubsection{Evaluation}

All work concerning development and demonstration of this technology will be completed at ORNL. There is no direct interface required by Facilities Support to support this TTP.

\subsection{TTP RL421213 DOE Complex Buried Waste Assessment}

\subsubsection{Task Description}

This TTP will provide funding for determination of technical bases for a retrieve/treat/dispose, in situ treatment, or a leave in place decision relative to millions of cubic feet of buried low level, transuranic, and mixed waste. This task will also summarize those characteristics for buried waste in the entire DOE system so that BWID will gain a better understanding of which technologies should be developed and demonstrated to meet DOE complex environmental restoration needs.

\subsubsection{Evaluation}

Work completed by this TTP is an evaluation study. No demonstration will be directly supported by this TTP, so no direct interface is required by Facilitics Support to support this TTP. 


\subsection{TTP SR121201 SRL Characterization Technology}

\subsubsection{Task Description}

Various gases are produced from TRU waste as a result of radiolysis and volatile organic compounds (VOCs). Characterization of the gases and the quantities produced is required to determine appropriate handling, treatment, and disposal technologies. This task will evaluate gases produced by TRU waste in a controlled environment. Gases will be sampled and quantified using gas chromatography (GC) and mass spectrometry (MS).

\subsubsection{Evaluation}

This TTP provides funding for Westinghouse Savannah River Complex (WSRC) to characterize off-gases from TRU waste so that recommendations can be made concerning methods of off-gas control during remediation processes. All work concerning this TTP will be completed at WSRC. There is no direct interface required by Facilities Support to support this TTP. 
Table 1. Technology vs. requirements matrix.

\begin{tabular}{|c|c|c|c|c|c|}
\hline $\begin{array}{l}\text { Technology to be } \\
\text { Demonstrated }\end{array}$ & Capacity & $\begin{array}{c}\text { Demonstration } \\
\text { Schedule }\end{array}$ & Waste Form & $\begin{array}{l}\text { INEL } \\
\text { Location }\end{array}$ & Wo \\
\hline $\begin{array}{l}\text { Cryogenic Retrieval }{ }^{\mathrm{a}, \mathrm{b}} \text { (Dave } \\
\text { Valentich) ID } 121203\end{array}$ & $\begin{array}{l}4 \text { pits, } 9^{\prime} \times 9^{\prime} ; 12^{\prime} \times \\
12^{\prime} \text { access pit }\end{array}$ & $\begin{array}{l}\text { Starts } 5 / 92 ; 2 \\
\text { weeks to } \\
\text { mobilize; } 4 \\
\text { week } \\
\text { demonstration }\end{array}$ & $\begin{array}{l}\text { In situ; not } \\
\text { contaminated }\end{array}$ & Cold test pit & None \\
\hline $\begin{array}{l}\text { Monolithic confinement }{ }^{c} \text { (Steven } \\
\text { Phillips) RL } 421212\end{array}$ & NA & $\begin{array}{l}\text { Late fiscal year } \\
\text { (FY) }-93\end{array}$ & $\begin{array}{l}\text { Not } \\
\text { contaminated } \\
\text { soil }\end{array}$ & $\begin{array}{l}\text { RWMC or } \\
\text { basalt quarry }\end{array}$ & None \\
\hline $\begin{array}{l}\text { TRU Waste Treatment Technology } \\
\text { (David Stefanko) SR } 101201\end{array}$ & $*$ & TBD & $\begin{array}{l}\text { Not } \\
\text { contaminated }\end{array}$ & Cold test pit & None \\
\hline $\begin{array}{l}\text { Non-Intrusive Sensing of Objects } \\
\text { (J.R. Duray ID001201 }\end{array}$ & * & $6 / 92-3 / 94$ & $\begin{array}{l}\text { Not } \\
\text { contaminated } \\
\text { soil }\end{array}$ & $\begin{array}{l}\text { Acid pit, cold } \\
\text { test pit }\end{array}$ & $\begin{array}{l}\text { Offici } \\
\text { work }\end{array}$ \\
\hline $\begin{array}{l}\text { Rapid and Cost-Effective } \\
\text { Luminescence Spot Test (Tuan } \\
\text { Vo-Dinh) OR121201 }\end{array}$ & * & $4 / 93-3 / 94$ & $\begin{array}{l}\text { Soil } \\
\text { contaminated } \\
\text { with PCBs }\end{array}$ & $\begin{array}{l}\text { To be } \\
\text { determined }\end{array}$ & $\begin{array}{l}\text { Offic } \\
\text { (not n } \\
\text { at INF } \\
\text { bench }\end{array}$ \\
\hline $\begin{array}{l}\text { Biological Destruction of Nitrates } \\
\text { (Graham Andrews) ID } 121204\end{array}$ & * & $\begin{array}{l}\text { Lab scale FY- } \\
92 \text {; bench scale } \\
\text { FY-93; RWMC } \\
\text { FY-94 }\end{array}$ & $\begin{array}{l}\text { Nitrate salt } \\
\text { wastes from } \\
\text { Pad A }\end{array}$ & RWMC & $\begin{array}{l}\text { Office } \\
\text { PC, fa } \\
\text { FY-93 } \\
\text { high b } \\
\text { includ } \\
\text { RWM }\end{array}$ \\
\hline $\begin{array}{l}\text { Pad A Treatability Study } \\
\text { (stabilization/vitrification }{ }^{d} \text { (Peter } \\
\text { Shaw) ID121205 }\end{array}$ & 30,55 -gal drums & $10 / 92-6 / 93$ & $\begin{array}{l}\text { Pu-containing } \\
\mathrm{NO}_{3}{ }^{*} \text { salts }\end{array}$ & Pad A & \\
\hline $\begin{array}{l}\text { Pad A Treatability (dissolution } \\
\text { process) } \\
\text { (Peter Shaw) ID121205 }\end{array}$ & 30, 55-gal drunus & $10 / 92 \cdot 6 / 93$ & $\begin{array}{l}\text { Pu-containing } \\
\mathrm{NO}_{3}^{-} \text {salts }\end{array}$ & Pad A & Don't \\
\hline $\begin{array}{l}\text { Field Demonstration of } \\
\text { Characterization Technologies } \\
\text { (David Shropshire) ID } 121213\end{array}$ & - & $3 / 92-6 / 93$ & $\begin{array}{l}\text { Soil containing } \\
\text { buried metal } \\
\text { objects }\end{array}$ & $\begin{array}{l}\text { SDA, Cold } \\
\text { Test Pit }\end{array}$ & \\
\hline
\end{tabular}




\begin{tabular}{|c|c|c|c|c|c|c|c|}
\hline \multirow[b]{2}{*}{ Work Space } & \multirow{2}{*}{$\begin{array}{l}\text { Secondary Waste } \\
\text { Storage }\end{array}$} & \multicolumn{5}{|c|}{ Utility } & \multirow[b]{2}{*}{ Other Requirements } \\
\hline & & Power & Waler & Steam & Air & Fuel & \\
\hline$\leftleftarrows$ & $\begin{array}{l}\text { Retrieved waste } \\
\text { will be stored for } \\
\text { further testing }\end{array}$ & $440 \mathrm{v}$. & No & No & No & No & $\begin{array}{l}\text { Help expediting NEPA approval; } \\
\text { emergency medical services }\end{array}$ \\
\hline$=$ & NA & \multicolumn{5}{|c|}{ Self-contained vendor equipment } & None \\
\hline$\therefore$ & * & \multicolumn{5}{|c|}{ - } & $\begin{array}{l}\text { Excavation equipment; operations \& } \\
\text { maintenance personnel }\end{array}$ \\
\hline $\begin{array}{l}\text { space. PC, } \\
\text { bench }\end{array}$ & • & \multicolumn{5}{|c|}{ * } & $\begin{array}{l}\text { Base maps of R.WMC; survey grids; } \\
\text { boreholes }\end{array}$ \\
\hline $\begin{array}{l}\text { s. phone, PC } \\
\text { oncessarily } \\
\text { E,L); lab } \\
J\end{array}$ & $\begin{array}{l}\text { "Follow standard } \\
\text { disposal } \\
\text { procedures." }\end{array}$ & \multicolumn{5}{|c|}{ - } & $\begin{array}{l}\text { Samples for analysis; assistance for } \\
\text { field sampling }\end{array}$ \\
\hline $\begin{array}{l}\text { c, phone, } \\
\text {-a) at TRA } \\
=3 ; 2000 \mathrm{ft}^{2} \\
=b i y \text { space } \\
=\text { ting office at } \\
-1 C\end{array}$ & $\begin{array}{l}\text { "Follow existing } \\
\text { best practice for } \\
\text { disposal of low- } \\
\text { level and } \\
\text { nonhazardous solid } \\
\text { wastes." }\end{array}$ & Yes & Yes & • & • & $\begin{array}{l}\text { Nat- } \\
\text { ural } \\
\text { gas }\end{array}$ & None \\
\hline . & NA & Yes & \multicolumn{4}{|c|}{ Self-contained vendor equipment } & None \\
\hline 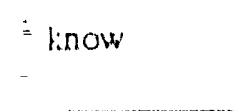 & $\mathrm{NA}$ & \multicolumn{5}{|c|}{$\begin{array}{l}\text { Self-contained vendor equipment may require water } \\
\text { supply) }\end{array}$} & None \\
\hline
\end{tabular}


Table 1. (continued).

\begin{tabular}{|c|c|c|c|c|c|}
\hline $\begin{array}{l}\text { Technology to be } \\
\text { Demonstrated }\end{array}$ & Capacity & $\begin{array}{l}\text { Demonstration } \\
\text { Schedule }\end{array}$ & Waste Form & $\begin{array}{c}\text { INEL } \\
\text { Location }\end{array}$ & Wc \\
\hline \multicolumn{6}{|l|}{$\begin{array}{l}\text { Ice Electrodes (David Glenn) } \\
\text { ID121211 }\end{array}$} \\
\hline $\begin{array}{l}\text { Ultrasonic detoxification (Hann } \\
\text { Huang) } \mathrm{CH} 201202\end{array}$ & $8 \cdot 12 \mathrm{gpm}$ & $3 / 94-3 / 95$ & $\begin{array}{l}\text { Aqueous; } \\
\text { contaminated } \\
\text { soil }\end{array}$ & $\begin{array}{l}\text { RWMC (?) } \\
\text { TBD in FY- } \\
93\end{array}$ & $\begin{array}{l}\text { Office } \\
\text { accom } \\
\text { BD; }\end{array}$ \\
\hline
\end{tabular}

${ }^{a}$ Cryogenic retrieval vendor will provide a self-contained test set-up. The cold test pit ${ }^{b}$ Cryogenic retrieval and the weather shield appear on the same TTP. 'If deep drilling is necessary, the PI expects INEL to do the support work. ${ }^{d}$ This demonstration was closed out March 2, 1992.

*This information has not been received from the Principal Investigators. 


\begin{tabular}{|c|c|c|c|c|c|c|c|}
\hline \multirow[b]{2}{*}{ k Space } & \multirow{2}{*}{$\begin{array}{c}\text { Secondary Waste } \\
\text { Storage }\end{array}$} & \multicolumn{5}{|c|}{ Utility } & \multirow[b]{2}{*}{ Other Requirements } \\
\hline & & Power & Water & Steam & Air & Fuel & \\
\hline \multicolumn{8}{|c|}{ • } \\
\hline $\begin{array}{l}\text { yodation: } T \\
\text { rk bench }\end{array}$ & Yes & $1 \mathrm{MW}$ & $\begin{array}{l}\text { Clean } \\
\text { process }\end{array}$ & No & No & No & $\begin{array}{l}\text { Soil storage hopper, contaminated } \\
\text { feed; process control: power, } \\
\text { pressure, temperature monitoring; } \\
\text { GC monitoring; hazardous liquid } \\
\text { effluent }\end{array}$ \\
\hline
\end{tabular}

may require rebuilding after this demonstration is completed. 
Table 2. Level milestone schedule.

\section{Buried Waste Integrated Demonstrati}

TRU - Contaminated Plts and Trenches RI/FS

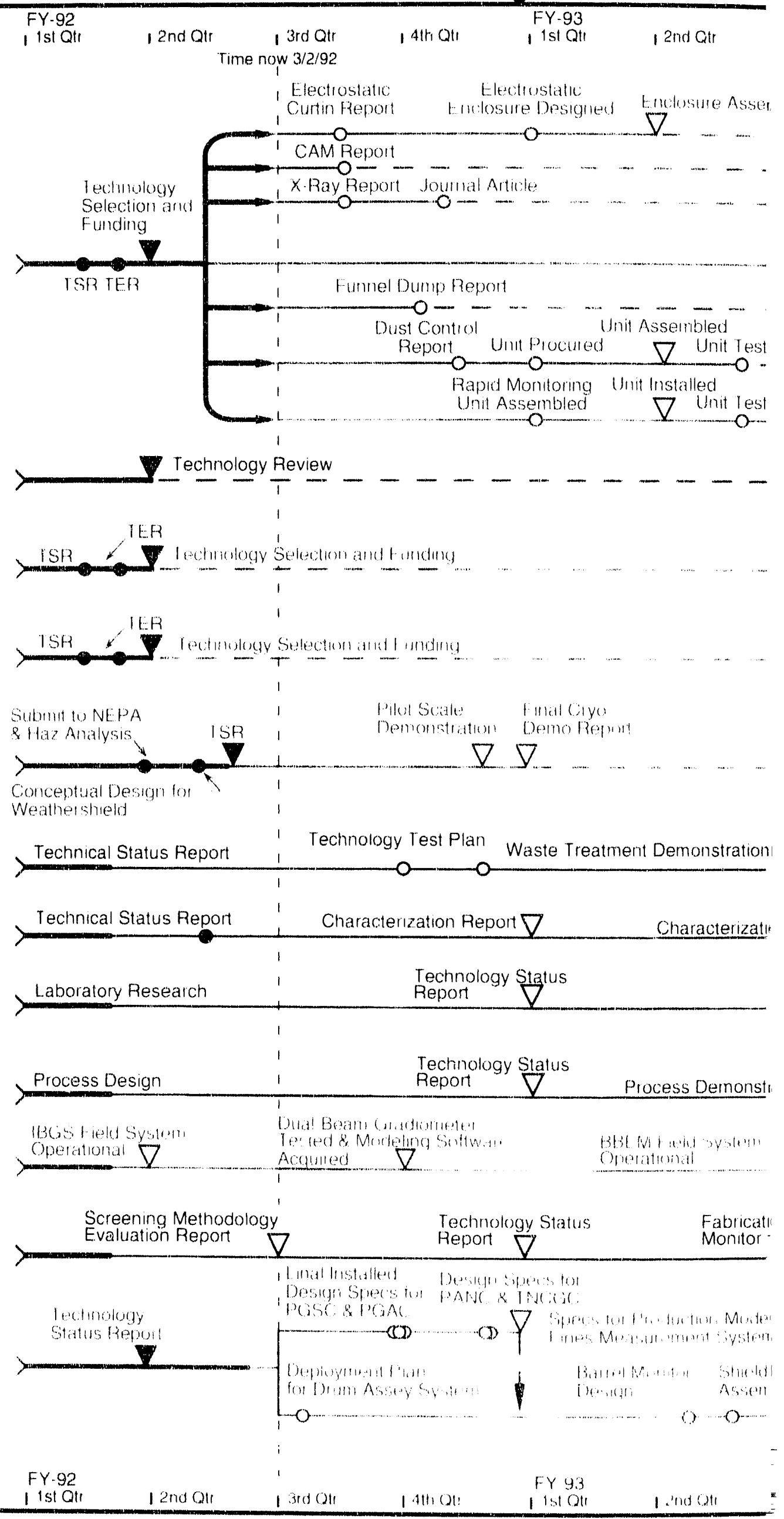

Retrieval Support Contamination

Control Technologies

ID-121210 (ID-0797DT)

NDE/NDA Peer Review

(on hold) HQ-021203 (HQ-920016)

Thermal Treatment Peer Review (on hold) ID-021202 (ID-0798-DT)

Characterization Peer Review (on hold) ID.021204 (ID-0799-DT)

Cryogenic Retrieval ID-121203 (ID.0604.DT)

TRU Waste Treatment Methodology SR 101201 (SR.0088.AA)

SRL Demonstration Characterization Technology SR-121201 (SR-0620-AA)

Ultrasonic Process for Detoxifying

Groundwater and Soil

$\mathrm{CH} .201202(\mathrm{CH} .115300)$

Destruction of PCBs in Mixed Wastes OR 101202 (OR 0373-AL)

Non-Intrusive Sensing of Environmental Objects and Species

ID-001201 (ID-2520 -GA)

Luminescence Spot Test for

Screening PCBs

OR-121201 (OR-0.367 AY)

Radiological and Hazardous Material Measurement System

ID-121212 (ID-0502-DT) 
1 3rd Qtr

1 4th Ott

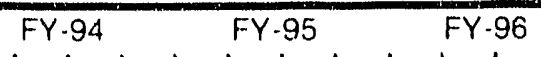

FY-97
FY-98

BWII) F-valuation

Reprit Decision Process sser bibed

- ...... - - - ...

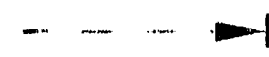

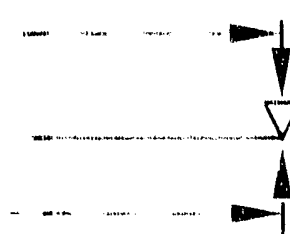

lesterd

j-

lesterit

lestert

Haptd Monitoming

7 Final Report

$-m-\infty-\infty-\infty-\infty$

RI/FS Scoping

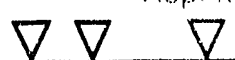

Draft SOW Draft Work Plan Draft RI/FS

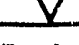

Draft ROD
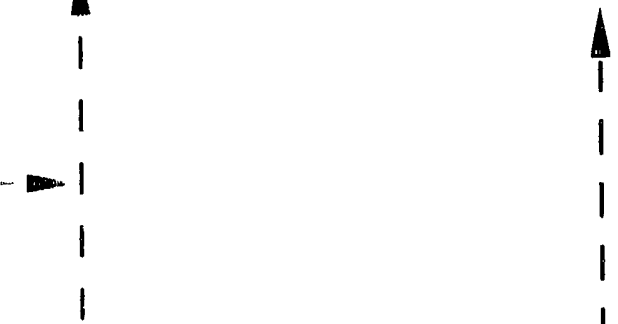

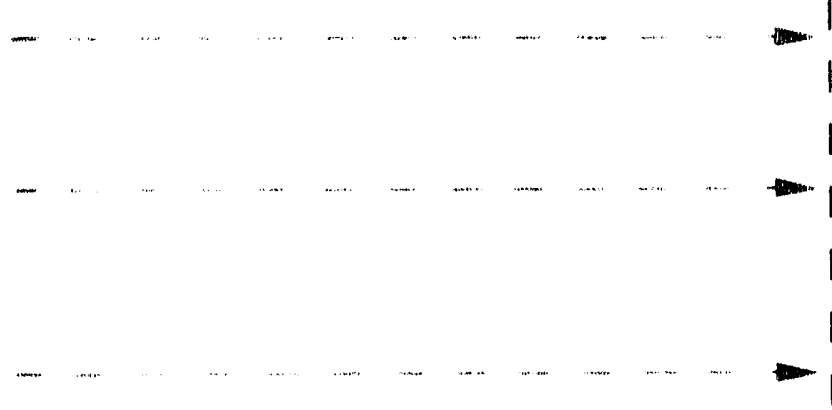

$-$
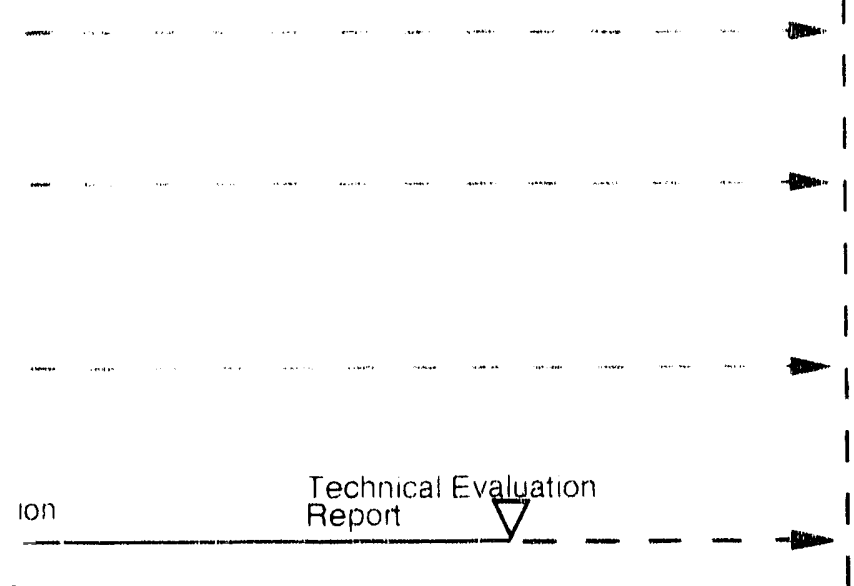

ation Demonstration

Techrical Evaluation Feport<smiles>[TeH]</smiles>

Technical Evaluation

istration Report

Thation

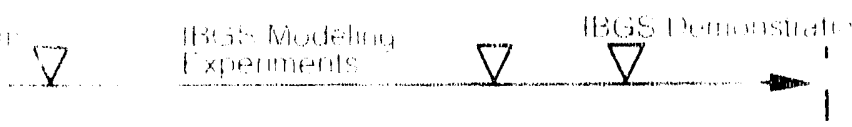

ation of Portable or 7

Field Test Technology Transter Repont

$\because 11$

HA2 Amonthes

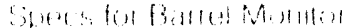

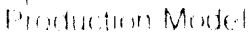

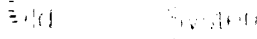

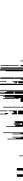

()

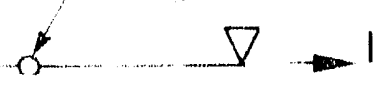

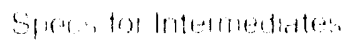

$$
\text { Menten lentintun Mistum }
$$

FY 9d, FY.95, , FY.96
Legend

$\diamond$ Decision Point

$\nabla$ Key Milestones

- Major Milestones

- Idaho TTPS 
Table 2. (continued).

Buried Waste Integrated Demonstrati

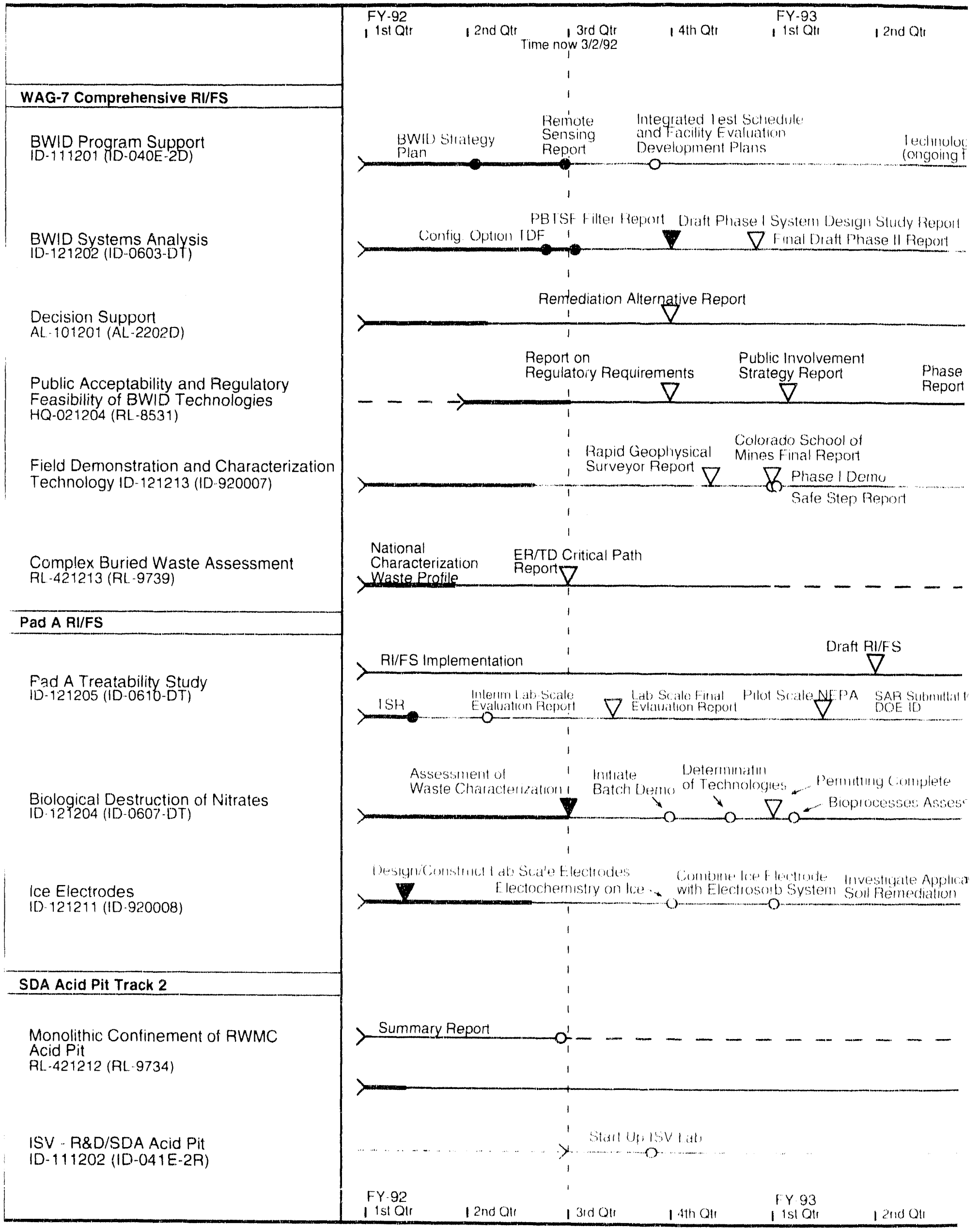




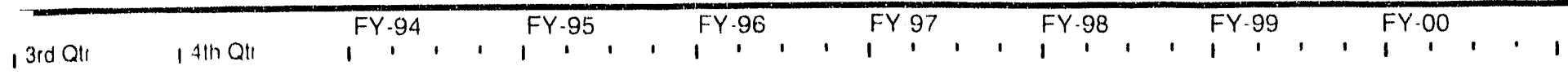

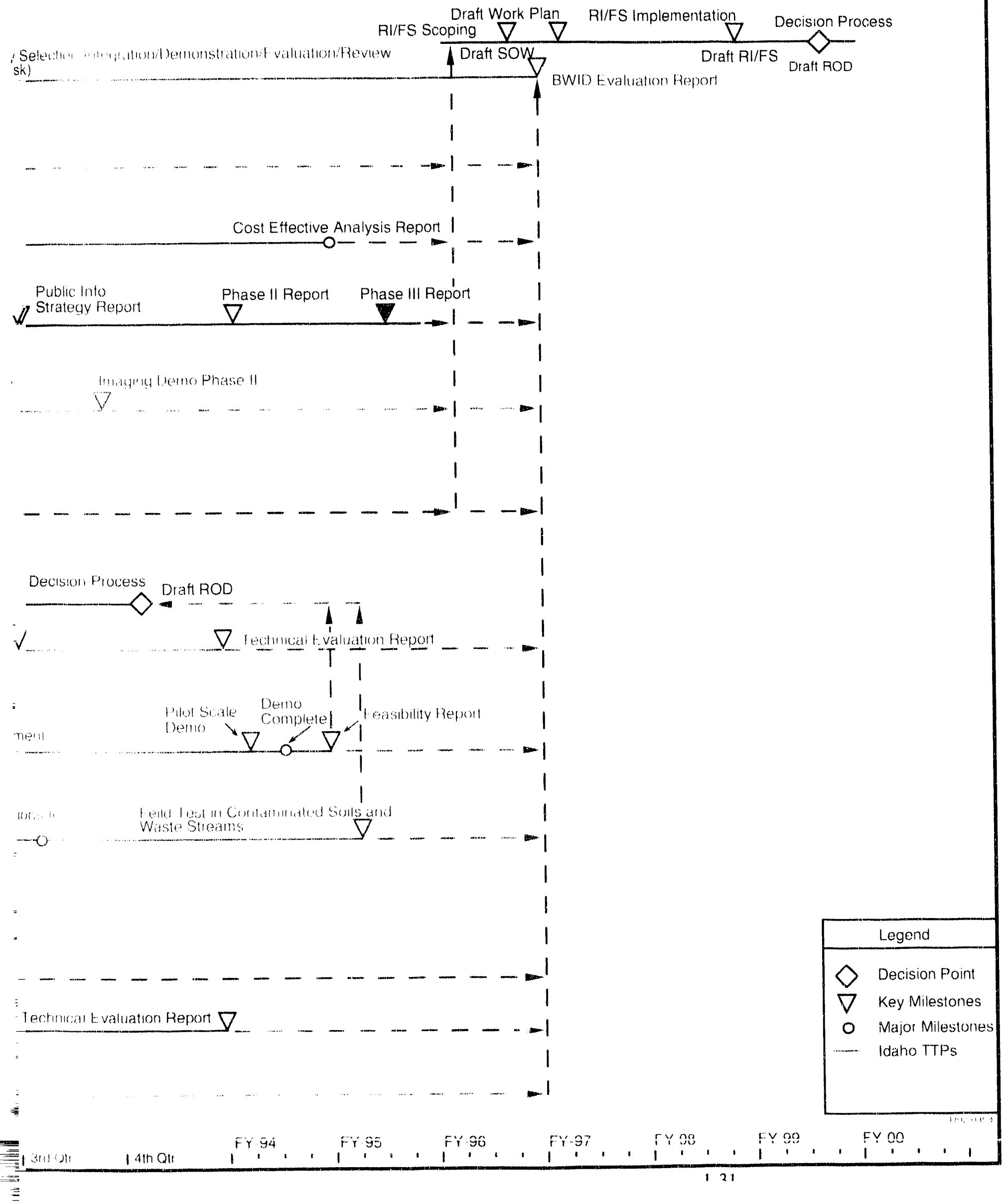




\title{
FACILITIES EVALUATIONI REPORT
}

\author{
Section 2
}

\section{An Operational Evaluation of Existing INEL Facilities with Potential for Supporting BWID Technology Demonstration Projects}




\section{Facilities Evaluation Report}

SECTION 2

\section{An Operational Evaluation of Existing INEL Facilities with Potential for Supporting BWID Technology Demonstration Projects \\ 1. INTRODUCTION}

This section has been prepared to provide an in-depth evaluation of INEL facilities that may be considered for use in BWID activities related to technology demonstration. The evaluation is presented from an operational perspective and identifies positive and negative characteristics of the facilities related to the set up and completion of technology demonstrations for BWID. Prior to BWID use of these facilities or associated equipment within the facilities, a routine preoperational check of equipment will be required. In some cases a facility/technology demonstration readiness review may be required prior to beginning technology demonstration activities.

In addition to this introduction, a background section and a section with detailed evaluation data on each facility are incorporated in this document. The format for detailing the evaluation data is straightforward and simple. Each facility evaluation section contains an abstract, facility description data, facility operational evaluation data, and facility existing condition data.

Data collected and presented in this report should be a valuable aid to BWID personnel in identifying available INEL facilities having the appropriate capabilities relative to BWID technology demonstration project requirements. 


\title{
2. FACILITY EVALUATIONS
}

\subsection{Facility Evaluation Report Building No. WMO-601}

\author{
Evaluation Performed by: P. A. Sloan \\ Date: November 25, 1991
}

\subsubsection{Abstract}

A highbay with an overhead crane, and the location and relative close proximity of the Waste Management Operation (WMO)-601 complex to the RWMC are highly desirable characteristics relating to testing of BWID-coordinated technologies. Fire and electric code problems, coupled with a friable asbestos problem in the office building will make the development and upgrading of the facility for BWID use very expensive.

Current plans as identified in the Site Development Plan are to demolish the WMO-60)1 office building in FY-92 and use the high bay area for cold storage.

Even with limitations on heating and no utilities in the high bay, there is still some potential for its use since it does have separate electrical power feeders and could be used for technology demonstration.

The CFA landlord has responsibility for upkeep of the complex, and building occupation is coordinated by the Facility Planning Space Utilization organization.

\subsubsection{Facility Description}

A description of the building, its location in relationship to the RWMC, and its accessibility in terms of roads, fences, and gates follows. WMO-601 is an office building and high bay facility that is located next to Experimental Breeder Reactor 1 (EBR-1) approximately two miles from the RWMC (see Figures 1 and 2). Access to the facility is good and the roads to the facility are also good. The facility is located inside a security fence with access controlled by the CFA Landlord.

\subsubsection{Operational Evaluation of the Bullding}

Operational evaluation of the facility is accomplished by answering questions related to various facility characteristics as follows:

1. Is the facility set up efficiently for technology testing?

The preliminary Identification and Ranking Report developed by Industrial Engineering listed the positive aspects of the facility as having a 60 by $75 \mathrm{ft}$ high bay that has a ceiling height of $25 \mathrm{ft}$. Other than electricity, there are no functioning utilities available in the facility at this time. 
2. Is the facility heated; does it have restrooms, eating facilities, work shop areas, high bays, large access doors, cranes, etc.

The facility has a high bay work area that is equipped with an overhead crane (no capacity listed). The high bay has no utilites and is inadequately heated by electric heat.

The office building has office space and restrooms, as well as eating areas. Currently the facility has no heating capabilities and the asbestos insulation in the facility is releasing friable material into the atmosphere above Occupational Safety and Health Act (OSHA) limits and, therefore, makes the facility unsuitable for occupation. Until the asbestos problem is corrected, the facility cannot be used.

3. What is the facility hazard classifications? Is there any active National Environmental Policy Act (NEPA) documentation associated with the facility?

Hazard classification is not applicable for this building. The office building is scheduled for demolition and the high bay will be converted for use as a cold storage area.

4. Is pow'er available to the facility? If so, how much, at what voltage, single or three phase?

Power is available to the facility. The office building and the high bay are fed electrical power independently through motor control centers (MCCs). The MCCs are fed from the site grid via a $300 \mathrm{kVA} 3$-phase transformer.

5. What utilities are available (sewage, industrial water, waste water return, air, demineralized water)?

The office facility is in a shutdown condition and access is restricted due to the asbestos problem. Domestic water, fire water, and electrical power are available.

The high bay has electrical power available, as well as a dry pipe fire protection system. Due to the heating problems identified earlier, there is no water or sewage capability available at the high bay.

6. When will the facility be available for "se?

Plans are to demolish the office building in the near future. Plans for the high bay are to use it for cold storage. Use of the high bay could be arranged by contacting the Facility Planning Space Utilization organization.

\subsubsection{Facillty Existing Condition}

Evaluation of the facility existing condition is accomplished by answering questions related to various facility characteristics as follows: 
1. Is there an asbestos problem in this facility?

During building inspection it has been detemined that the floors in the facility are tiled with asbestos tile. The building is also insulated with asbestos. Apparently, the insulation is breaking down as there is a friable asbestos problem in the office facility that exceeds OSHA limits for occupancy.

No asbestos problems have been identificd in the high bay facility.

2. Do facility Inspection Logs identify any other problems with this facility?

Several problems have been identified with the office facility. The heating boiler is obsolete and no longer functional. The building also does not meet current fire and electrical codes.

No information on the high bay was obtained that indicated a problem other than insufficient heating capacity.

3. Are there any fire or electrical code problems with the existing facility?

The office building does not meet current fire and electrical codes.

No information on the high bay was obtained that indicated a problem other than insufficient heating capacity.

4. What do the Annual Work Plan, the Long-Range Work Plan, or Construction Activity work plans show for this facility?

The Site Development Plan shows this facility classified as a marginal facility and the demolition of the WMO-601 office facility is scheduled in FY-92. The high bay is to be left in place as a cold storage facility.

\subsection{Facility Evaluation Report Building No. CFA-665}

Evaluation Performed by: P. A. Sloan

Date: November 26, 1991

\subsubsection{Abstract}

Building CFA-665 is an excellent facility to house technology demonstration activities. It has a high bdy area of approximately $60 \times 200 \mathrm{ft}$ with roll-up doors all along one side. It also has a large open area on the opposite side of the building accessed by roll-up doors. Office space and storage rooms are also included. The facility should become available in FY-94.

Deficiencies associated with the facility include some electric code violations and also some minor problems with the roof. All deficiencies are listed in the Backlog of Maintenance and Repair (BMAR) and will be repaired as resources allow. None of these problems are severe enough to prevent the normal operation of the facility as required by its current tenants. 
Power and ventilation concerns may limit the facility's uscfulness for technology demonstration. The building is limited in power availability as it has only one $75 \mathrm{kVA}$ mansformer supplying power. It may be possible to upgrate the power system to the lacility, if reguired. No studies have been done that identify costs of such an electrical upgrade. The building ventilation system may lack sufficient air volume tumover rates required for some types of activities. Activities with a potential for excessive enissions could be affected by this.

\subsubsection{Facillity Description}

CFA-665 is a large building with a gross estimated floor area of $27,000 \mathrm{ft}^{2}$. It is listed as being in poor condition and was constructed in 1951. It is located in the Central Facilities Area approximately nine miles from the RWMC (see Figures 1 and 3). Roads are good and the building has excellent accessibility. There are no other fences hampering access to the building after accessing the main security checkpoint.

\subsubsection{Operational Evaluation of the Building}

Operational evaluation of the facility is accomplished by answering questions related to various facility characteristics as follows:

1. Is the facility set up efficiently for technology testing?

CFA-665 is the current bus and vehicle service repair facility. There are several large bays set up for bus access, as well as smaller bays for standard vehicle access. All of the bays are accessed via roll-up garage doors with at least $12 \mathrm{ft}$ of overhead. Bays on the south side of the building have 15-17 $\mathrm{ft}$ access doors and at least $30 \mathrm{ft}$ of overhead room. Water, air, power, and ventilation are supplied to each bay. It may be possible to set up several technology demonstration experiments in this facility depending on specific technology power and utility requirements.

2. Is the facility heated; does it have restrooms, eating facilities, work shop areas, high bays, large access doors, cranes, etc.

The facility is divided into many high bays with hydraulic lifts installed in some of the bays. Two 5-ton bridge cranes are part of the facility, as well as an overhead track mounted system with three 5-ton electric hoists. Heat, water, restrooms, storage rooms, office space, and lunchrooms are availabic in this facility.

3. What is the facility hazard classification? Is there any active NEPA documentation associated with the facility?

The facility has a low hazard classification. Any new technology to be set up in the building will require its own NEPA documentation. 
4. Is power available to the facility? If so, how much, at what voltage, single or three phase?

Power to the facility is supplied by one $75 \mathrm{kVA} 3$-phase transformer. Voltage is listed as greater than 440 . Each bay has a 30 amp., 3-phase, 440 volt outlet, as well as various 110 volt outlets.

5. What utilities are avaiiable (sewage, industrial water, waste water return, air, demineralized water)?

Water, air, and power are supplied to the building. There is no active process waste water system in the facility. Process drains are routed to the sewage system. Each bay has a sewage drain built into it.

6. When will the facility be available for use?

As stated above, the building is currently being used as a bus and vehicle repair facility. Construction on a new transportation complex is to start in FY-92. When the new complex is completed and repair services are transferred to it, the CFA-665 building will be empty and available for use. This should be accomplished in FY-94. Contact the Facility Planning Space Utilization organization for determining space availability.

\subsubsection{Facillty Existing Condition}

Evaluation of the facility existing condition is accomplished by answering questions related 10 various facility characteristics as follows:

1. Is there an asbestos problem in this facility?

No asbestos problems have been noted concerning this facility. If the building contains asbestos, no friable problems have been identified.

2. Do facility Inspection Logs identify any other problems with this facility?

The INEL Site Development Plan lists the building as being in poor condition. Inspection reports and the Backlog of Maintenance and Repair (BMAR) show that there are some electrical code problems that have to be addressed. Some minor repairs to the building are also noted, as well as repairs required for the roof. Work for these repairs will be completed as resources allow. There is also a concern that the ventilation system in the building may lack sufficient air volume turnover rates required for some types of activities.

3. Are there any fire or electrical code problems with the existing facility?

No fire code problems are listed in the BMAR. The electrical code problems are minor and identified in the BMAR. 
4. What do the Annual Work Plan, the Long-Range Work Plan, or Construction Activity work plans show for this facility?

A FY 92 line item construction project is identified for building a new transportation complex. Plans are to move into the new complex in 1994. This directly affects when building CFA- 665 will become available for other use. Long-range planning indicates that this building is to be used for covered storage in the future.

Outstanding maintenance items will be corrected as resources allow.

\title{
2.3 Facility Evaluation Report Building No. CFA-689
}

\author{
Evaluation Performed by: P. A. Sloan \\ Date: December 5, 1991
}

\subsubsection{Absiract}

The CFA-686, 688, and 689 building complex has many qualities desirable in a test facility. There is room in the high bay with adjoining office space, as well as lab facilities for setting up small demonstrations. The disadvantages are the (a) lack of a drain system for the high bay, (b) lack of a process retum water system for any of the buildings, and (c) lack of available space in the complex. Another problem is that the complex is listed as a low hazard facility, so no testing with radiological or hazardous materials would be allowed. The facility is occupied and full. Even with a new addition in the future, all space is allocated.

With the limitation for office and lab space in the central area, it scems unlikely that space for BWID use would become available; but there is some possibility that such space could be made available on a temporary basis for a BWID demonstration if building limitations and requirements are met.

\subsubsection{Facillty Descrlption}

A description of the building, its location in relationship to the RWMC, and its accessibility in terms of roads, fences, and gates follows. CFA-686, 688, and 689 is a complex of buildings comprised of two office buildings containing small lab facilities and offices that are attached to a high bay. The complex is located in the Central Facilities Area approximately nine miles from the RWMC (see Figures 1 and 3). Roads are good and the buildings have good accessibility. Once through the main security checkpoint coming into CFA. there are no other iences hampering access to the building

\subsubsection{Operational Evaluation of the Building}

Operational evaluation of the facility is accomplished by answering questions related io various facility characteristics as follows:

1. Is the factlin set up efficiently for technology testing?

CFA.686 is a $4(1 \times 1(X)$ ft high bay facility with a $25-\mathrm{ft}$ ceiling that is attached to CFA688. The high bay has electrical power and water supplied to it, but no drain system. 
CFA-688 and 689 are adjoining buildings that contain office space and small rooms set up as labs. All three of the buildings are listed as light lab facilities. Any technology demonstration sites in these facilities would be limited to small-scale demonstrations.

2. Is the facility heated; does it have restrooms, earing facilities, work shop areas, high bays, large access doors, cranes, etc.

The CFA-686 building is a high bay with a 5-ton bridge crane. It is supplied with water and power, but has no process drain system. CFA-688 and 689 together are an office complex with restrooms, heated office space, and small lab facilities in their interior.

3. What is the facility hazard classifications? Is there any active NEPA documentation associated with the facility?

This complex has a No Hazard classification. The complex is classilied as a light lab facility and cannot be used for radioactive or hazardous materials testing.

4. Is power available to the facility? If so, how much, at what voltage, single or three phase?

Power to the complex is supplied by two $1000 \mathrm{kVA}$, 3-phase transformers with voltage to the buildings Iisted in the Site Development plan as greater than 440 volts. The BMAR information on the complex indicates that a new $50 \mathrm{kVA}$ transformer is to be installed in the high bay for additional power.

5. What utilities are available (sewage, industrial water, waste water retwn, air, demineralized water)?

CFA.686, the high bay, has only power and water supplied to it. Power is supplied via two transformers totaling $165 \mathrm{kVA}$, and water is supplied via a $2 \mathrm{in.}$ water main. No other utilities are listed as being available for this building.

CFA-688 and 689 have industrial water, air, and sewage available for use. Drains provided for the buildings in this complex are limited to the sewage system. No process drain system is available.

6. When will the facility be alailable for use?

The complex is currently $100 \%$ occupied by an engineering group and there are no plans for vacating this space. Future modifications to the facility are planned to increase its capacity, but all of the new space is taken. There may be a possibility of obraining space in the complex on a temporary basis. Contact the Facility Planning Space Utilization organization for information regarding space acquisition. 


\subsubsection{Facility Existing Condition}

Evaluation of the facility existing condition is accomplished by answering questions related to various facility characteristics as follows:

1. Is there an asbestos problem in this facility?

The Site Development Plan lists the facility as being in good condition. No asbestos problems have been noted to date.

2. Do facility Inspection Logs identify any other problems with this facility?

No problems have been identified with the facility other than standard maintenance items.

3. Are there any fire or electrical code problems with the existing facility?

There have been some minor electrical code problems identified with the facility. They have been entered in the building maintenance tracking system and will be corrected as resources allow. No other problems have been identified.

4. What do the Annual Work Plan, the Long-Range Work Plan, or Construction Activity w'ork plans show' for this facility?

Construction of an addition to the CFA-689 building is planned for the purpose of adding more office and lab space to the complex, thereby relieving overcrowded conditions. The engineering organization is scheduled to move into the new space as soon as it becomes available.

\subsection{Facility Evaluation Report Building No. PBF-612 (WEDF)}

Evaluation Performed by: P. A. Sloan

Date: November 27. 1991

\subsubsection{Abstract}

Building PBF-612 has many attractive features. The high bay, with large roll-up doors on each end, has excellent access for most any size of equipment necessary. The building is clean and in good repair and is currently available for occupation upon request to the building manager. It also has adequate power capabilities for most technologies being considered by BWID, as well as having water, air, and adequate fire protection. Another attractive feature is the decontamination room with its filtered exhaust system. This ronm could be used for the safe demonstration of technologies with test programs requiring test matrices contaminated radioactively, as well as with hazardous materials.

The negative aspects of the facility are the lack of a functional process drain system and the potential fire protection problem due to the facility only having a 4-in. water line supplying all water. Due to the lack of a functional process drain system, the existing building is unsuitable for those technologies requiring this capability. If a process drain system is required, a new cold drain field could be installed if funding is available. 


\subsubsection{Facllity Description}

A description of the building, its location in relationship to the RWMC, and its accessibility in terms of roads, fences, and gates follows. The building is an office complex/high bay facility in good condition with approximately $11,000 \mathrm{ft}^{2}$ floor space and a basement. Access for installing equipment in the basement is provided via removabie floor pancls on the main floor. The building is located in the PBF area a few miles cast of the Central Facilities Area (CFA) and approximately 12 miles from the RWMC (see Figures 1 and 4). Roads to the facility are good. Responsibility for the facility currently lies with the Waste Engineering Development Organization which is part of the Waste Management Deparment. Access is through the PBF security gate.

\subsubsection{Operational Evaluation of the Bullding}

Operational evaluation of the facility is accomplished by answering yuestions related 10 various facility characteristics as follows:

1. Is the facility set up efficiently for technology testing?

The main floor of the facility consists of office spaces on the east side of the building with a high bay extending full length on the west side. The dimensions of the bay are $45 \times 100 \mathrm{ft}$ with a $25 \mathrm{ft}$ ceiling height. At each end of the high bay, there is an $11 \mathrm{ft}$ 10 in. roll-up door. There are welding outlets, water line drops, and air drops spaced fairly evenly along the high bay wall. Floor capacity varies and is as high as $500 \mathrm{lbs} / \mathrm{ft}^{2}$ depending upon where basement access panels are located. The facility also has a room that was previously set up as a laboratory. This room is now being used as an office.

One level below ground-level there is a sealed room with a filtered (HEPA) exhaust system designed to maintain the room at a negative pressure. Approximate size of the room is $20 \times 30 \mathrm{ft}$. Water supply drops have been installed at various locations in the room. No process drains exit the room. There is also a small area in the lower basement being used for PBF contaminated storage. This should not be a problem as the lower basement would have limited use.

2. Is the facility heated: does it have restrooms, eating facilitie:, work shop areas, high bays, large access doors, cranes, etc.

The facility is listed in good condition in the Site Development Plan. The building is heated and office space has baseboard heat. A 10-ton bridge crane, as well as a 2-ton chain hoist, are located in the high bay. The access doors are described above. The building has a felephone and communication system installed. 
3. What is the facility hazard classifications? Is there any active NEPA documentation associated with the facility?

The building has a low hazard classification and the Safety Analysis Report (SAR) reflects developing and testing the process of solidification of mixed radioactive and hazardous wastes. Testing of these processes was conducted in the contamination control room. This room has been decontaminated and is now clean. The SAR is currently under the control of the WERF document control system. Any technology setting up in this facility will have to provide their own system of document control and develop a hazard classification and SAR based on the technology installed.

4. Is power available to the facility? If so, how much, at what voltage, single or three phase?

The facility has 480 volt 3-phase welding outlets at various intervals. It has (wo $167 \mathrm{kVA}$ transformers supplying the switchgear inside the building. The main MCC is set up to provide approximately $300 \mathrm{kVA}$ al 480 volts to the facility.

5. What utilities are available (sewage, industrial water, waste water return, air, demineralized water)?

The facility has air, industrial water, and sewage service supplied to it. It no longer has the process waste system in service. All drains are plugged and the drain field is a RCRA listed cleanup site and can't be used any more. Process drains will now have to be handled by the extremely limited sewage system or a new drain system installed.

6. When will the facility be available for use?

Currently the facility is being used as a crafts shop and equipment storage area. It also has a small area in the lower basement being used for PBF-contaminated storage. Arrangements for making this building available for BWID use should be made through the Facility Plarning Space Utilization organization.

\subsubsection{Facillty Existing Condition}

Evaluation of the facility existing condition is accomplished by answering questions related to various facility characteristics as follows:

1. Is there an asbestos problem in this facility?

No asbestos problems exist in this facility. It has been cleaned and is in very good condition.

2. Do facility Inspection Logs identify any other problems with this facility?

No problems other than normal maintenance are evident with this facility. 
3. Are there any fire or electrical code problems with the existing facility?

Fire protection water to this facility is supplied by the PBF area. The building has a wet pipe sprinkler system for fire protection. A problem with marginal water pressure to the area has been identified, but pressures meet minimum requirements.

The electrical power supply to the building has been upgraded and meets code.

4. What do the Annual Work Plan, the Long-Range Work Plan, or Construction Activity work plans show' for this facility?

The Site Development plan indicates that this buildi.g is to be used for continued solidification testing. This is not the case. The buiding is available for technology testing. No major repairs are required or planned for this building.

\title{
2.5 Facility Evaluation Report Building No. PBF-613 (RMWSF)
}

\author{
Evaluation Performed by: P. A. Sloan
}

Date: December 4, 1991

\subsubsection{Abstract}

Building PBF-613 has many attractive features as did the Waste Engineering Development Facility (WEDF) (PBF-612), but it is scheduled for continued use as a RCRA low mixed radioactive hazardous waste storage area and, therefore, is not available for BWID use.

\subsubsection{Facillty Description}

A description of the building, its location in relationship to the RWMC, and its accessibility in terms of roads. fences, and gates follows. This building has the characteristics necessary to support activities requiring an office complex/high bay facility. It is located in the PBF area a few miles cast of the Central Facilities Area (CFA) and approximately 12 miles from the RWMC (see Figures 1 and 4). Roads to the facility are good. Responsibility for the facility currently lies with the Waste Engineering Development Organization which is part of the Waste Management Department. The building is currently being used as a radioactive mixed waste storage facility. Access is through the PBF security gate.

\subsubsection{Operational Evaluation of the Buliding}

Operational evaluation of the facility is accomplished by answering questions related to various facility characteristics as follows:

1. Is the facility set up efficiently for technology testing?

The building contains a high bay with 44.5 -ft ceiling. It has two wings atlached to the high bay that have 13-ft ceilings. The building has been set up as a storage area and is classified as a RCRA storage area for radioactive and mixed waste. It is not ser up as a test facility. 
2. Is the facility heated; does it have restrooms, eating facilities, work shop areas, high bays, large access doors, cranes, etc.

The building has a $50 \times 75$-ft high bay with a $44.5-\mathrm{ft}$ ceiling and a 12-ton crane. It is heated and has office space and restrooms. No eating areas are available as it is used as a mixed waste storage site.

3. What is the facility hazard classifications? Is there any active NEPA documentation associated with the facility?

The facility has a low hazard classification and also is a listed RCRA storage site for low-level mixed hazardous and radioactive waste.

4. Is power available to the facility? If so, how much, at what voltage, single or three phase?

The facility has a $750 \mathrm{kVA} 3$-phase transformer supplying power to it at 480 volts.

5. What utilities are available (sewage, industrial water, waste water return, air, demineralized water)?

Industrial water is supplied to the facility and a sewage system is in service. Process drains have been plugged and the drain system is no longer in service. Any process drains will now have to be handled by the limited sewage system.

6. When will facility be available for use?

The facility is currently listed as RCRA storage site for low-level mixed hazardous and radioactive waste and is being used for this purpose. The probability of this facility being used for other than waste storage is extremely minimal. If RCRA closure proceedings for this facility were to start now, it might become available for use sometime in FY-94. There are no plans to close out this facility as a RCRA storage site at this time, or in the near future. The facility will not become available in a time frame that would support BWID activities.

Questions concerning this facility should be addressed to the building manager.

\subsubsection{Facllity Existing Condition}

Evaluation of the facility existing condition is accomplished by answering questions related to various facility characteristics as follows:

1. Is there an asbestos problem in this facility?

There has been no asbestos problem identified with this facility. 
2. Do facility Inspection Logs identify any other problems with thls facility?

No problems other than normal maintenance are evident with this facility.

3. Are there any fire or electrical code problems with the existing facility?

Fire protection water to this racility is supplied by the PBF area. A problem with margnal water pressure to the area has been identified, but pressures meet minimum requirements.

No electrical problems have been identified with the facility.

4. What do the Annual Work Plan, the Long-Range Work Plan, or Construction Activity w'ork plans show' for this facility?

The building has been set up as a storage area and is classified as a RCRA sitorage area for radioactive and mixed waste. Plans as identified in the INEL Site Development plan indicate that the facility RCRA documentation will be upgraded to allow for storage of large quantities of low-level mixed waste in the future. No other plans have been identified for the facility.

\title{
2.6 Facility Evaluation Report Building No. TAN-645, 646
}

\author{
Evaluation Performed by: P. A. Sloan
}

Date: December 20, 1991

\subsubsection{Abstract}

Building TAN-645, 646 could be an excellent facility for setting up technology demonstrations. Ample quantities of power, steam, service water, and compressed air are available and accessible throughout the facility. It contains a high bay with a heavy crane capacity (a 50-ton and 5 ton unit) and easy access. It is one of the few accessible remaining facilities on the Site with a functioning process drain system. The building manager is very cooperative and willing to support new projects in this facility.

Disadvantages to the facility are its relatively limited space due to containing equipment from old projects and its long distance from the RWMC. If more space than currently available is required, demolition of the surplus equiprnent should not be costly.

A serious problem exists with the facility concerning the National Electric Code. Before any demonstration projects could be installed in the facility for testing, extensive and cost prohibitive electrical upgrades are required. A copy of a PROFS note from Don Long, an expert on the National Electric Code (NEC), is attached to this report as Appendix. A. Based on his findings, it will probably be cost prohibitive to use this building for anything other than storage.

\subsubsection{Facility Description}

A description of the building, its location in relationship to the RWMC, and its accessibility in terms of roads, fences, and gates follows. The TAN-645, 646 complex is two buildings joined 
logether to form an office/high bay complex. Tan-645 is the office area and TAN-646 is a high bay with two concrete pits installed for setting up test stands where research projects can be contained and operated. The complex is located at the Water Reactor Research Test Facility (WRRTF) at Test Area North (TAN). This facility is 32 miles north of the RWMC, has good roads, and is surrounded by a security fence (see Figures 1 and 5). Access to the facility is controlled by the building manager located in TAN-645 during normal working hours. Access on back shifts and weekends is controlled by INEL security at the TAN access gate.

\subsubsection{Operational Evaluation of the Bullding}

Operational evaluation of the facility is accomplished by answering questions related to various facility characteristics as follows:

1. Is the facility set up efficiently for technology testing?

The TAN- 646 building is a high bay facility that includes two pits set up for installing relatively large experimental test systems. Semiscalc equipment that has been placed out of service due to discontinuation of the program is still installed in one of the pits. The other pit is empty and available for use now. There is also some floor space (approximately $14 \times 35 \mathrm{ft}$ ) in the high bay that is still available for set up of test equipment. Power, steam, water, and compressed air are available and accessible throughout the facility. Associated with the high bay is the TAN-645 building, which is a control room/office complex. Room is available in this facility also.

Assuming no asbestos problems, it should be a relatively simple task to remove the old Semiscale equipment, as there is no identified use for the equipment and it is radiolog. ally clean. This would free up much space that could be used for technology demonstration.

2. Is the facility heaied; does it have restrooms, eating facilities, work shop areas, high bays, large access doors, cranes, etc.

There are restrooms, eating areas, office space, and a conference room available for use in the TAN-645, 646 complex. The high bay area has a 5-ton and 50-ton bridge crane with a large access door (approximately $15 \mathrm{ft} \mathrm{high)} \mathrm{on} \mathrm{the} \mathrm{north} \mathrm{end.} \mathrm{Room} \mathrm{is}$ also available for setting up shop areas, if required. All facilities are heated.

3. What is the facility hazard classifications? Is there any active NEPA documentation associated with the facility?

Hazard classification for the facility is currently listed as low hazard. Required NEPA documentation will be experiment dependent.

4. Is power available to the facility? If so, how much, at what voltage, single or three phase?

Ample power is available to the facility. One 250() $\mathrm{kVA}$ and two $750 \mathrm{kVA}$ transformers supply three-phase power to the facility at 480 volts. 
5. What utilities are avalable (sewage, industrial water, waste water return, air, demineralized water)?

The facility has power as listed above, compressed air, an air conditioning system, a steam and condensate system, and a demineralized water system. It also has an adequate sewage system along with a functional process drain system.

A few years ago the old boilers were removed from TAN-645. Provisions for steam in the building were made by installing new boilers in building TAN-641, and then running a new steam line from 641 to 645 to supply the tolal WRRTF area with steam. The system is in good condition.

6. When will the facility be available for use?

The high bay contains floor space and two pits for setting up experiments. One pit has equipment installed in it that was used for the now discontinued Semiscale Program. The other pit is empty and is available for use now. Some floor space in the high bay is being used for a thermal testing program conducted by EG\&G Idaho for the Savannah River Laboratory. An abandoned test control room is also installed in the high bay and may be of some use. There is approximately $15 \times 35 \mathrm{ft}$ of $1100 \mathrm{r}$ space available for use in the high bay area at this time. A few rooms in the back of the building are being used for a relatively small test program conducted by EG\&G Idaho for the Federal Aviation Administration (FAA). When this project is completed, this space will become available. The project is scheduled to be completed in the first quarter of FY-92. The building manager is very willing to accommodate new projects in this facility.

\subsubsection{Facility Existing Condition}

Evaluation of the facility existing condition is accomplished by answering questions related to various facility characteristics as follows:

1. Is there an asbestos problem in this facility?

Major work on the TAN-645, 646 complex has been completed where asbestos was removed from the facility and new building insulation was installed. Some of the steam and condensate lines may still be insulated with asbestos. This will not be a problem unless maintenance on those lines requires the insulation be removed. No other problems have been identified, and a friable asbestos problem does not exist.

2. Do facility Inspection Logs identify any other problems with this facility?

On November 21, 1991, while touring the WRRTF area, the building manager informed me that there was a leaking fuel line between Buildings 645 and 641 , as well as a potential for two leaking fuel storage tanks. The leaking fuel line and one fuel tank have been removed, and the other tank is scheduled for removal soon. A replacement fuel tank is necessary and will soon be installed and placed in service. During fuel system repairs, a leaking process drain line was discovered and has since been repaired. 
The INEL Site Development Plan lists the building as being in good condition. Inspection reports and the Backlog of Maintenance and Repair (BMAR) show that no problems have been identified with the facility other than standard maintenance items.

Don Long, an NEC expert, was involved with a building walk through and found many electrical code and OSHA problems with the facility. His PROFS note to R. W. Bonnenberg conceming these problems is attached as Appendix A.

3. Are there any fire or electrical code problems with the existing facility?

There are some problems with the electrical switch gear. The electrical code has changed since the electrical system was installed and the distance between the existing MCC panels does not meet the new code. The petitioning process is now in progress for EG\&G Idaho to obtain a variance in this matter from the Department of Energy (DOE).

Fire systems are in good condition. No problems with the system have been identified.

4. What do the Annual Work Plan, the Long-Range Work Plan, or Construction Activity work plans show' for this facility?

The building manager is not aware of any major construction plans for the facility and the Site Development Plan lists none.

\subsection{Facility Evaluation Report Building No. TAN-640, 641}

Evaluation Performed by: P. A. Sloan

Date: January 3, 1992

\subsubsection{Abstract}

Building TAN 640, 641 could be an excellent facility for setting up technology demonstration. Ample quantities of power, steam, service water, and compressed air are available and accessible throughout the facility. It contains two high bays with bridge cranes in each bay and easy access. It is one of the few accessible remaining facilities on the Site with a functioning process drain system. The building manager is very cooperative and willing to support new projects in this facility.

The facility will not be available for occupation until mid-1992 at the earliest.

\subsubsection{Facillty Description}

A description of the building, its location in relationship to the RWMC, and its accessibility in terms of roads, fences, and gates follows. The TAN-640, 641 buildings are an office/high bay complex located at the Water Reactor Research Test Facility (WRRTF) at Test Area North (TAN). This facility is 32 miles north of the RWMC, has good roads, and is surrounded by a security fence (see Figures 1 and 5). Access to the facility is controlled by the building manager located in TAN645 during normal working hours. Access on back shifts and weekends is controlled by INEL security at the TAN access gatc. 


\subsubsection{Operational Evaluation of the Bullding}

Operational evaluation of the facility is accomplished by answering questions related to various facility characteristics as follows:

1. Is the facility set up efficiently for technology testing?

The TAN-640 building is a high bay facility that includes two high bay areas with 50-ft ceilings and a 35-ft roll-up door for each bay. Each of the high bays contains an overhead bridge crane. The crane capacities are 5 tons and 10 tons, respectively. Power, steam, water, and compressed air are available and accessible throughout the facility.

Associated with and connected to the TAN-640 building is the TAN-64! building which is a control room/office complex.

2. Is the facility heated; does it ha'e restrooms, eating facilities, work shop areas, high bays, large access doors, cranes, etc.

There are restrooms, eating areas, and office space available for use in the TAN-640, 641 complex. The high bay areas each have overhead cranes with capacities of 5 tons and 10 tons, respectively, with large roll-up access doors on the north end of each bay. A small machine shop is installed in TAN-641 and room is also available for setting up other shop areas if required. All facilities are heated.

3. What is the facility hazard classifications? Is there any active NEPA documentation associated with the facility?

Hazard classification for the facility is currently listed as fow hazard. Hazard classification for the facility will be upgraded to moderate hazard in order to accommodate the sodium and potassium (NAK) disposal process in the near future.

NEPA documentation requirements will be experiment dependent.

4. Is power alailable to the facility? If so, how much, at what voltage, single or three phase?

Ample power is available to the facility. Dray.ings in the Site Development Plan show that two transformers supply three-phase power to the facility at 480 volts, one at $10(x) \mathrm{kVA}$ and the other at $225 \mathrm{kVA}$. 
5. What utilities are available (sewage, industrial water, waste water return, air, demineralized water)?

The facility has power as listed above, compressed air, an air conditioning system, a steam and condensate system, and a demineralized water system. It also has an adequate sewage system along with a functional process drain system.

A few years ago, new boilers were installed in building TAN-641 to supply the total WRRTF area with steam. The system is in good condition.

6. When will the facility be available for use?

The facility is currently in use supporting the development of a NAK disposal process and a Savannah River flow loop test program. Room in this facility will not be available until mid-1992 at the earliest.

\subsubsection{Facillty ExIsting Condition}

Evaluation of the facility existing condition is accomplished by answering questions related to various facility characteristics as follows:

1. Is there an asbestos problem in this facility?

Many of the steam and condensate lines in this complex are insulated with asbestos. This will not be a problem unless maintenance on those lines requires the insulation be removed. No other problems have been identified, and a friable asbestos problem does not exist.

2. Do facility Inspection Logs identify any other problems with this facility?

The INEL Site Development Plan lists the building as being in good condition. Inspection reports and the Backlog of Maintenance and Repair (BMAR) show that no problems have been identified with the facility other than standard maintenance items.

3. Are there any fire or electrical code problems with the existing facility?

There are some problems with the electrical switch gear. The electrical code has changed since the electrical system was installed and the distance between the existing MCC panels does not meet the new code. The petitioning process is now in progress for EG\&G Idaho to obtain a variance in this matter from DOE. Fire systems are in good condition. No problems with the system have been identified.

4. What do the Annual Work Plan, the Long-Range Work Plan, or Construction Activity work plans show for this facility?

The building manager is not aware of any major construction plans for the facility and the Site Development Plan lists none. 


\title{
2.8 Facility Evaluation Report Building No. TAN-607
}

\author{
Evaluation Performed by: P. A. Sloan \\ Date: December 20, 1991
}

\subsubsection{Abstract}

Building TAN-607 has many attractive features. There are various high bay areas that could be used in support of BWID programs. Power in ample supply is available on either a conmercial or an emergency bus with diesel generator back up. The facility has demineralized water as well as air, domestic water, and sewage available in most areas. It has active hot cells and a large hot shop with certified operations personnel that could be made available for BWID contaminated testing requirements.

Other than the PREPP facility, most of the space in this building is currenly occupied and in use for hot shop operations. Three Mile Island fuel is currently being stored in the storage pool. Space not in use at this time would be available and WMTO operations support personnel would be available to support BWID projects on a limited basis.

Due to the facility's current moderate hazard classification, a significant effort will be required to addend safety documentation associated with the facility as well as develop appropriate environmental documentation prior to installing a test program within the facility.

\subsubsection{Facllity Description}

A description of the building, its location in relationship to the RWMC, and its accessibility in terms of roads, fences, and gates follows. The TAN-607 building is a very large facility with ownership divided between two of the Sitc contractors. It has many characteristics attractive 10 BWID) for technology demonstrations. It is located in the Technical Support Facilities (TSF) area of Test Area North (TAN) 32 miles north of the RWMC, has good roads, and is inside the TAN security area (sec Figures 1 and 6). Access to the TAN area is controlled by INEL security forces around the clock. Part of the TAN-607 building is controlled and administered by Babcock and Wilcox (B\&W) for the Special Manufacturing Capability (SMC) project which occupies the southern part of the building. This is a Department of Defense project and access is restricted to security and B\&W personnel only. Access to the rest of the building is controlled by EG\&G liaho personnel working for the Waste Management TAN Operations (WMTO) group. Any facilitics that would be available for BWID use would be controlled by EG\&G ldaho personnel.

\subsubsection{Operational Evaluation of the Bullding}

Operational evaluation of the facility is accomplished by answering questions related to various facility characteristics as follows:

1. Is the facility set up efficiently for technolegy testing?

Curreally the accessible part of the building houses the mothballed Processing Experimental Pilot Plant (PREPP) and the operational TAN Hot Cells facility. Most areats of the facility are in use, but those areas that migh be made available have power and utilities that could be adapted for BWID use. 
2. Is the facility heated; does it have restrooms, eating facilities, work shop areas, high bays, large access doors, cranes, etc.

There is office space, eating areas, restrooms, heat, and shop areas throughout the facility. Operations personnel as well as a maintenance group, are also associated with this facility. Other capabilities are listed below.

The PREPP area has a high bay with limited utilities and power, is located in the west side of the building, has no crane, and has direct access outside via a $15-\mathrm{ft}$ high rollup door and a standard personnel door. There are also some rooms close to the high bay that might be available for office space or shop areas.

The warm shop is a large high bay area that has a 30/5-ton bridge crane, is radiologically and chemically clean, and has limited utilities available.

The Hot Shop is a contaminated high bay area with a 50-ton overhead crane for unloading fuel casks, etc. There is power, water, and air available in this area. There is also access to the fuel storage pool from the hot shop. There are hot cells available with limited utilities and remote master/slave manipulators. The cells have leaded glass windows for shielded viewing into the cells.

The hot cells annex (TAN-633), also considered part of this complex, has four hot cells as described above; one is radiologically clean. This area has limited utilities available. Water, air, and a significant amount of power are available. Process drains are restricted to sewage system capacity. Hot (radioactive) drains in this area are plugged and out of service.

3. What is the facility hazard classifications? Is there any active NEPA documentation associated with the facility?

The PREPP facility, mentioned above, is mothballed and has an inactive hazard classification. The Hor Cells Facility (HCF) is in operation and has a moderate hazard classification. Any activities associated with the HCF will require an addendum to the WMTO Safety Analysis Report. stand alone NEPA documentation, and a stand alone Health and Safety Plan.

4. Is power available to the facility? If so, how much, at what voltage, single or three phase?

The PREPP facility has its own power supply from the power grid rated at $1(0) 0 \mathrm{kVA}$. TAN-607 motor control centers are fed from a transformer rated at $1500 \mathrm{kVA}$. Power is available at 480 volts, 220 volts, and 115 volts.

The facility has 480 volt power available on either commercial or vital power distribution systerns. The vital power is backed up by a $1000 \mathrm{~kW}$ diesel generator set. 
5. What utilities are avalable (sewage, industrial water, waste water return, air, demineralized water)?

The TAN-607 complex has industrial water, potable water, and air available throughout the facility. Demineralized water is available in some parts of the facility. There is a process water drain system that services limited areas of the facility. Sewage service is available throughout the facility. The hot cells area also has a Hot Waste collection drainage system that is in service. Steam is supplied to the facility from the TAN boiler facility located in building TAN-603. Steam is not normally supplied during the summer months.

6. When will facility be available for use?

Some areas in the facility are not in use and are available now. Arrangements for available space will have to be coordinated with the facility manager.

\subsubsection{Facllity Ex/sting Condition}

Evaluation of the facility existing condition is accomplished by answering questions related to various facility characteristics as follows:

1. Is there an asbestos problem in this facility?

Some of the old steam and water piping, some equipment areas, and some spaces within the facility are insulated with asbestos. Some equipment areas within the facility are cleared for normal access, but administrative controls require that a Safe Work Permit (SWP) be initiated prior to any work being completed. When funding is made available by DOE, the asbestos will be removed. Most areas within the facility have no asbestos problems.

2. Do facility Inspection Logs identify any other problens with this facility?

Problems listed for this facility include the above mentioned asbestos removal, root repairs scheduled to be completed this summer, and normal maintenance items to be repaired when personnel and funding are available.

3. Are there any fire or electrical code problems with the existing facility?

Fire code problems have been noted conceming the lack of an adequate fire protection system in the TAN-633 annex 10 TAN-607. The entire TAN area fire protection system is in violation of the fire code at this time. An upgrade has been planned to correct the problem, but will require adequate funding from DOE to accomplish the upgrade. Minor electric code problems have been noted and are scheduled for upgrade as personnel and funding become available. 
4. What do the Annual Work Plan, the Long-Range Work Plan, or Construction Activity work plans show' for this facility?

The Site Development Plan lists no major construction plans for the facility. A 10-year plan is either in place or being developed to decontaminate the facility and shut down hot shop operations.

\subsection{Facility Evaluation Report Building No. TAN-630}

Evaluation Performed by: P. A. Sloan

Date: January 10, 1992

\subsubsection{Abstract}

A cursory investigation of Building TAN-630 depicts it as an ideal place for BWID technology demonstration. Water, air, steam, the containment vessel with its overhead crane, ample room, office space, and an abundance of power are all characteristics that normally would make this an ideal facility for BWID use. Upon closer inspection, however, the facility has many serious problems. The basic facilities were constructed in 1959 and remained operational through 1985. The Loss of Fluid Test (LOFT) reactor systems were then decommissioned and the reactor and some support systems were removed. The facility has since been decontaminated, with the exception of the radioactively-contaminated liquid drain systems and some support equipment in the containment basement. When constructed, building codes, electric codes, and fire protection codes were much different. Cost estimates for the required facility upgrades to bring the facility into compliarce with current OSHA, fire, and electrical codes is approximately 11 million dollars.

There is some possibility of using the upper level containment and the Initial Engine Test (IET) building for BWID demonstration purposes. Use would be very limited as there is limited availability of utilities and power in these areas, and there is currently no fire protection available. Currently the facility is in a partial shut down mode with plans to complete shut down this fiscal year.

\subsubsection{Facllity Description}

A description of the building, its location in relationship to the RWMC, and its accessibility in terrns of roads, fences, and gates follows. The TAN-630 complex is comprised of TAN-630, 650, and 624. TAN-650 is a reactor containment building with the reactor removed and the building decontaminated. The other buildings are support facilities and still contain much of the reactor support equipment. The complex is located at Test Area North (TAN) which is 32 miles north of the RWMC, has good roads, and is inside the TAN security area (see Figures 1 and 7). Access to the TAN area is controlled by INEL security forces around the clock.

\subsubsection{Operational Evaluation of the Building}

Operational evaluation of the facility is accomplished by answering questions related to various facility characteristics as follows: 
1. Is the facility set up efficiently for technology testing?

As mentioned above, the complex is comprised of three adjoining buildings. TAN . 630 contains the decommissioned LOFT control and Data Acquisition and Visual Display System (DAVDS) rooms, office space, and the support equipment rooms located in the basement. TAN-650 is comprised of the empty containment vessel and its support building with decommissioned LOFT support equipment is still in place. TAN-624 (IET Bldg) is a high bay building located in front of the containment railroad door.

In their current condition, it would be difficult to set up a process in this complex. Power and utilities could be made available in the containment and IET with appropriate modifications.

2. Is the facility heated; does it have restrooms, eating facilities, work shop areas, high bays, large access doors, cranes, etc.

The facility boilers have been condemned and are not operational. Steam is provided from Specific Manufacturing Capacity (SMC) on a temporary basis to supply heat in the facility this winter for freeze protection. There are restrooms, eating areas, and office spaces available. The containment vessel is approximately $90 \mathrm{ft}$ tall with a 50/10-ton circular overhead crane. The IET building is a high bay with no crane, no water, no utilities, and limited power. There is room within the facilitics complex to set up shop areas.

3. What is the facility hazard classifications? Is there any active NEPA documentation associated with the facility?

The facility is in a shut down condition and has a low havard classification. NEPA documentation requirements would be experiment dependent.

4. Is power available to the facility? If so, how much, at what voltage, single or three phase?

The facility has redundant feeders supplying three-phase power to it via a north and south substation. The north substation has four $13.8 \mathrm{kV} / 480 \mathrm{~V}$ transformers with a total capacity of $5000 \mathrm{kVA}$. The south substation has two $13.8 \mathrm{kV} / 480 \mathrm{~V}$ transfonmers with a total capacity of $2500 \mathrm{kVA}$.

5. What utilities are available (sewage, industrial water, waste water return, air, demineralized water)?

The facility has the capability of supplying industrial water, soft water, demineralized water, potable water, and instrument air. No steam is available in the facility other than the minimum amount supplied by SMC for freeze protection. Currently the facility is in a partial shutdown condition and all utilities other than for fire protection are isolated and secured. 
6. When will the facility be available for use?

As stated above, the facility is in a shutdown condition. Modification and refurbishing on a large scale will be required in order to use the facility for anything other than storage of nonflammable materials. A proposed schedule for completion of the required refurbishment spans approximately two years. The facility is available now for storage of nonflammable items.

\subsubsection{Facillty Existing Condition}

Evaluation of the facility existing condition is accomplished by answering questions related to various facility characteristics as follows:

1. Is there an asbestos problem in this facility?

The facility has extensive asbestos problems. A walk-through survey was completed by J. M. Brooks of the Facilities and Maintenance Department Compliance Support Group that identifies and quantifies the problem. The asbestos would have to be removed and new insulation installed before the facility could be occupied.

2. Do facility Inspection Logs identify any other problems with this facility?

As stated above, the steam supply boilers have been condemned and are out of commission. Without steam for heating, all water systems will have to be drained and secured, including the industrial water system as well as the fire protection systems. This will scverely limit facility availability and use.

Some areas with associated piping and equipment located in the containment basement have not been decontaminated.

3. Are there any fire or electrical code problems with the existing facility?

An electrical safety audit was performed by D. C. Long to evaluate the condition of the existing facility systems and equipment. The electrical systems and equipment are outdated in several compliance areas. The most economical way of upgrading the systems would be to abandon the old systems and install new equipment in those areas of the facility to be occupied.

A Fire Safety evaluation was completed on the facility. Many problems were noted, and it is apparent that it will be very costly to bring the facility up to current code requirements prior to being placed in service.

4. What do the Annual Work Plan, the Long-Range Work Plan, or Construction Activity work plans show' for this facility?

Current plans are to secure all utilities in the facility and place it in a shutdown mode. This work is planned to begin in mid-1992. The facility will be restricted for use only as a nonflammable storage facility. 
Studies have been completed by the Project Management Il Unit relating 10 a rough estimate for placing the facility in service again This study and its associated estimatc considered only the TAN-630 building and the upper level of the containment vessel and its entrance building TAN-624 (the IET building). All reactor support systems were excluded from the study. Cost is estimated to be approximately 11 million dollars and approximately two to three years to bring these limited facilities up to current standards. 


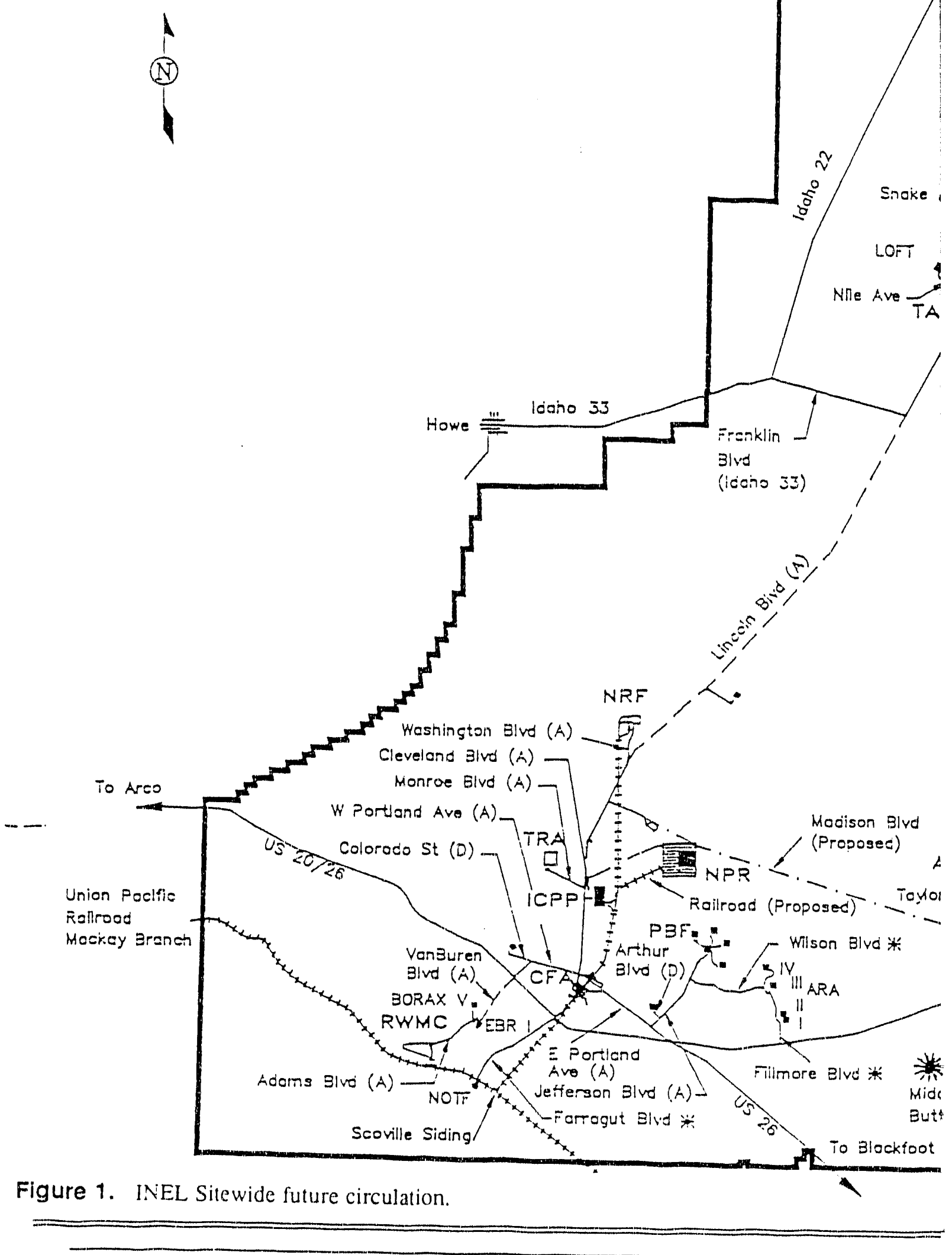




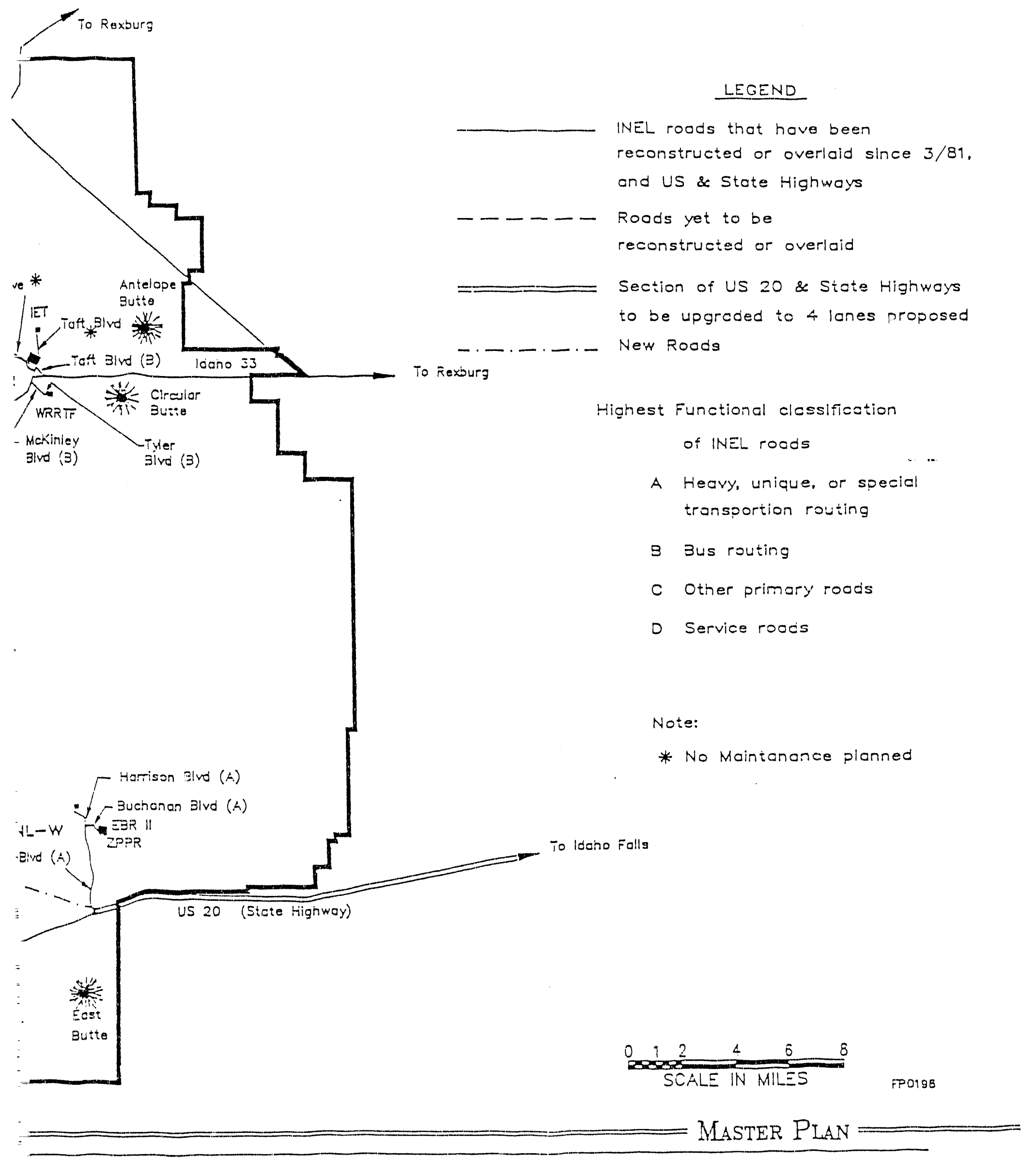




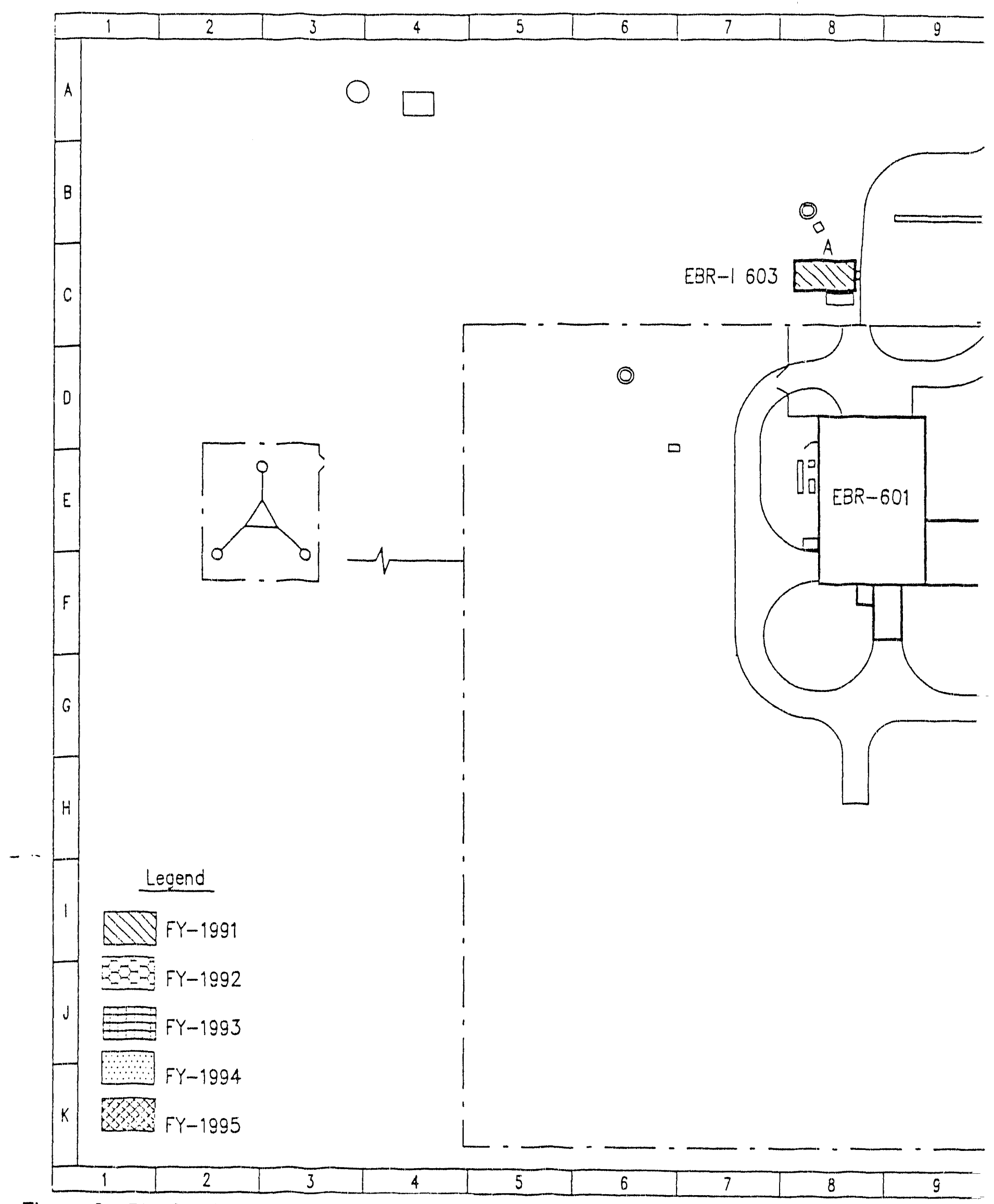

Figure 2. EBR-1 project map. 


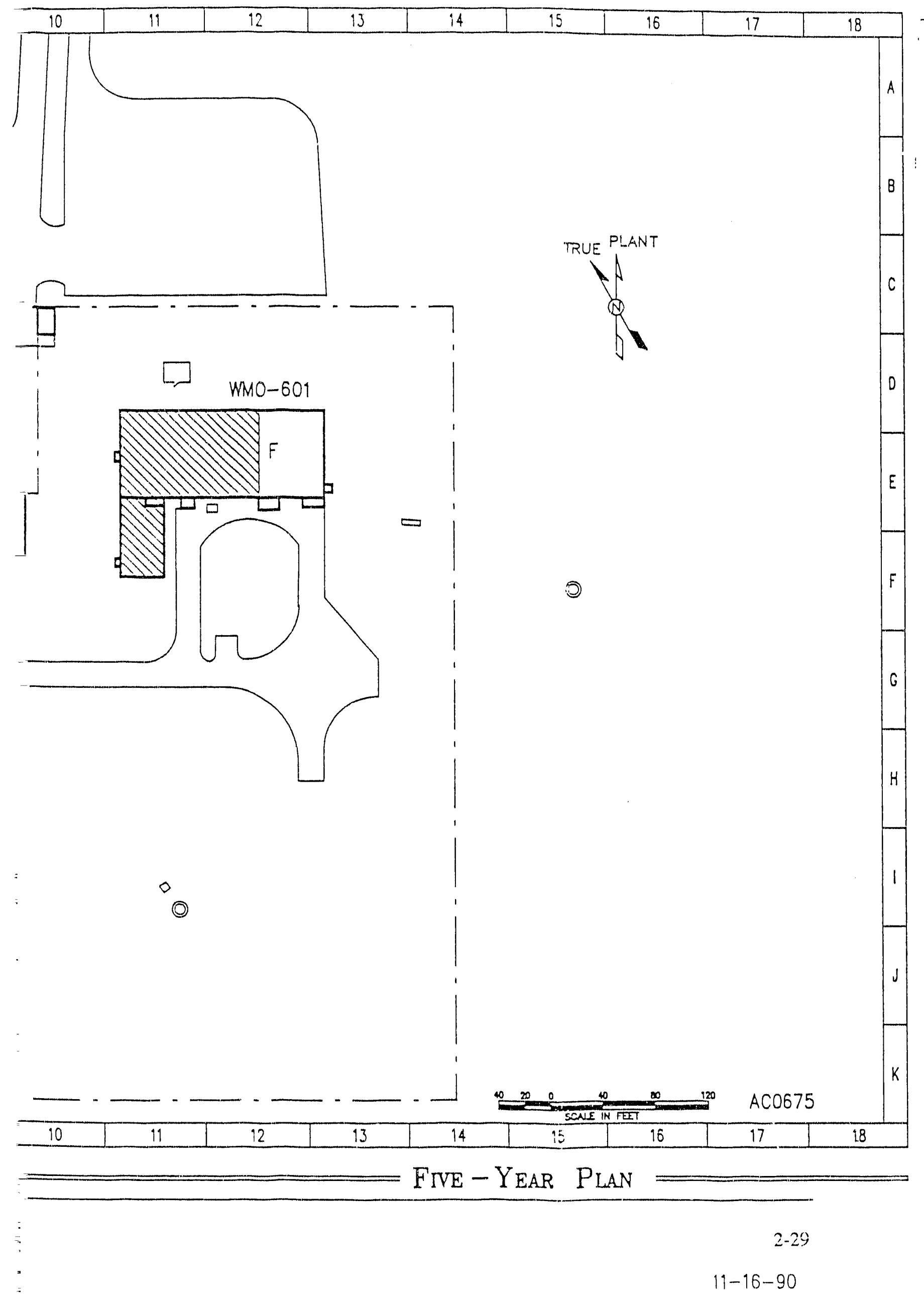




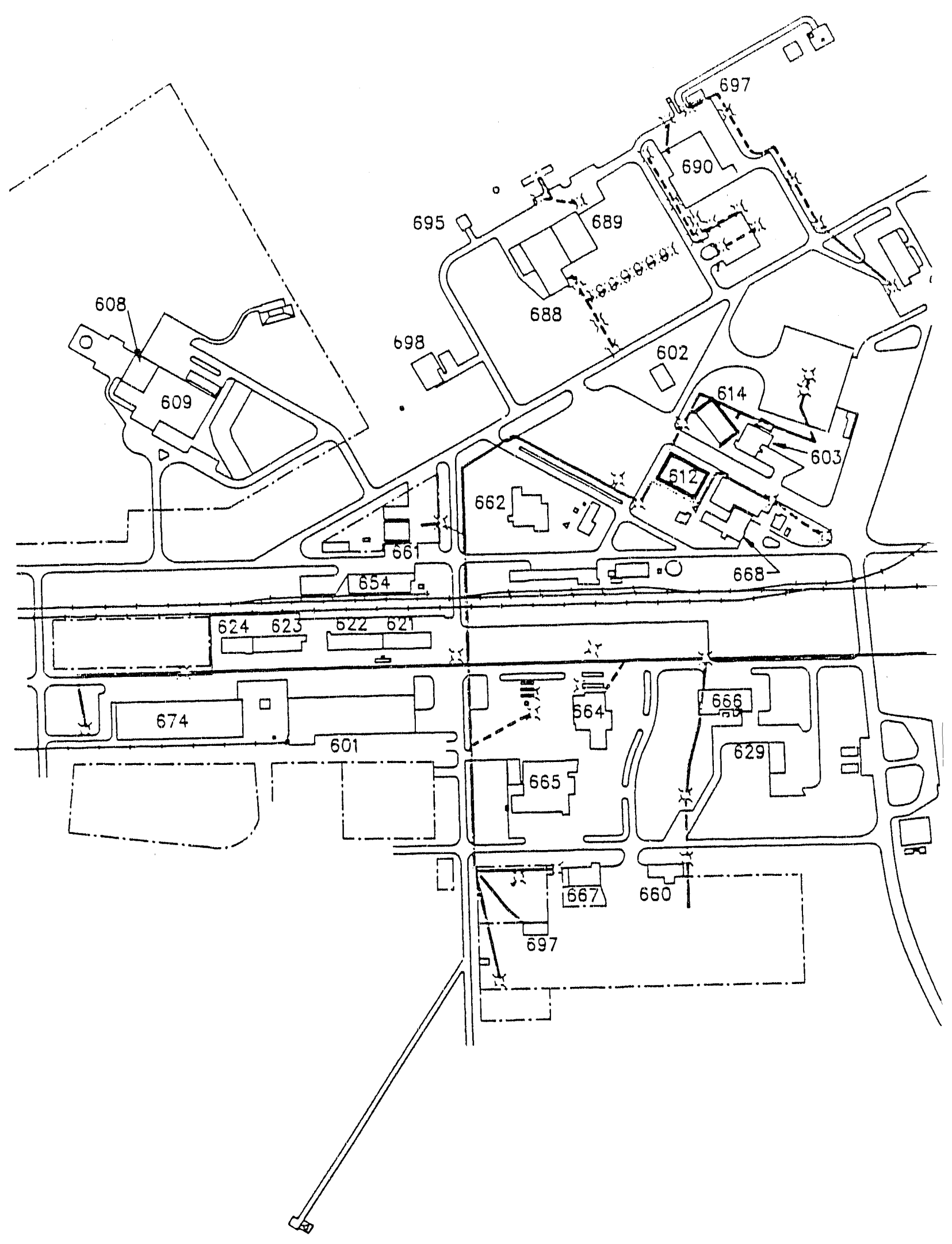

Figure 3. Area lighting at the Central Facilities Area. 


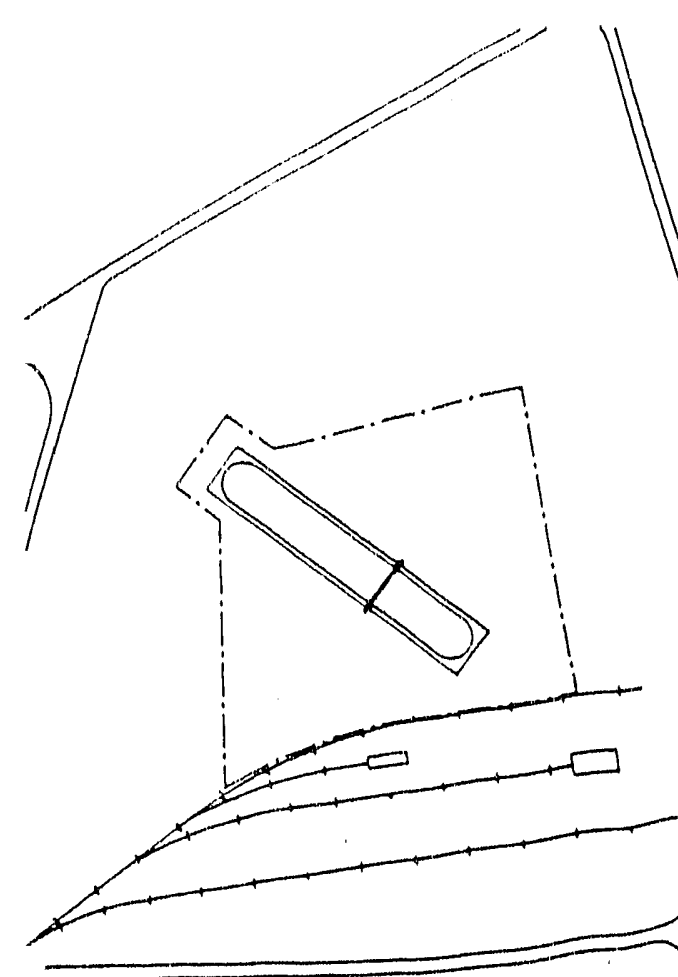

H
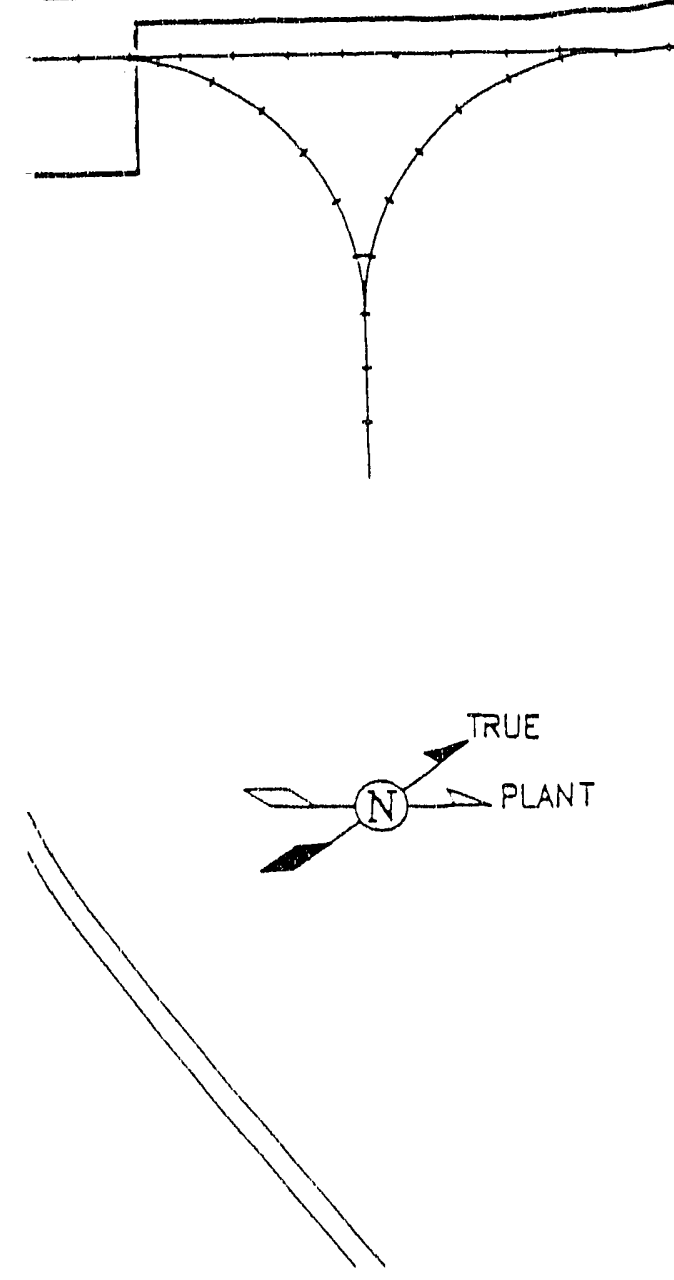

$\rightarrow_{\text {PLANT }}^{\text {TRUE }}$
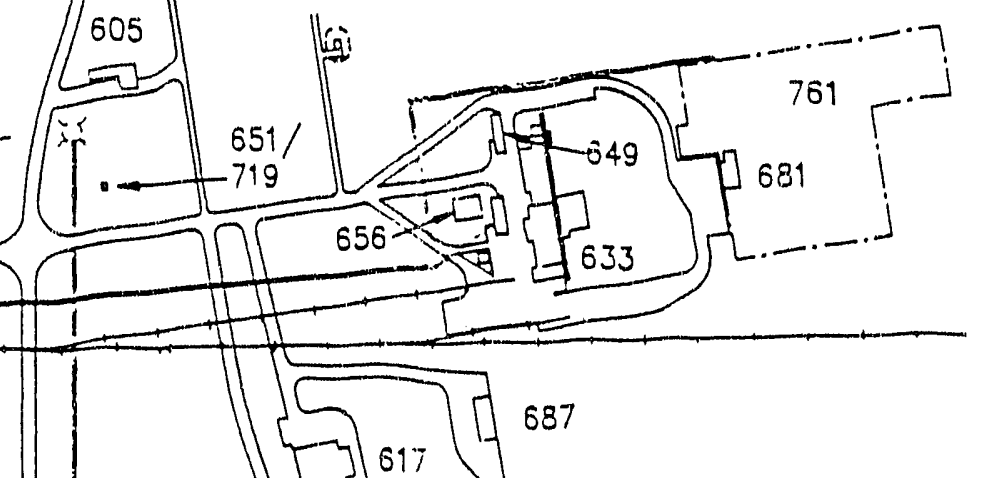


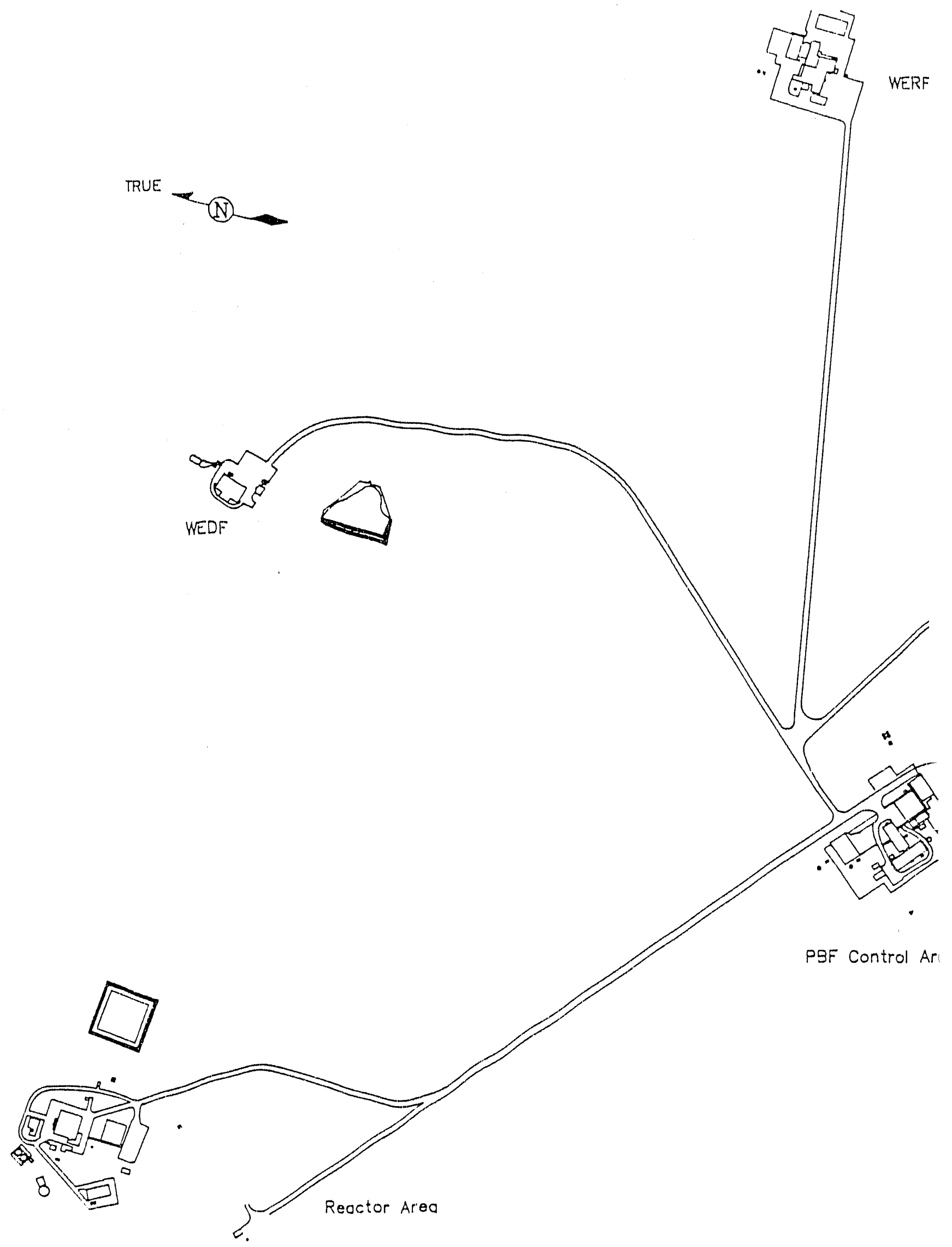

Figure 4. PBF plot plan. 

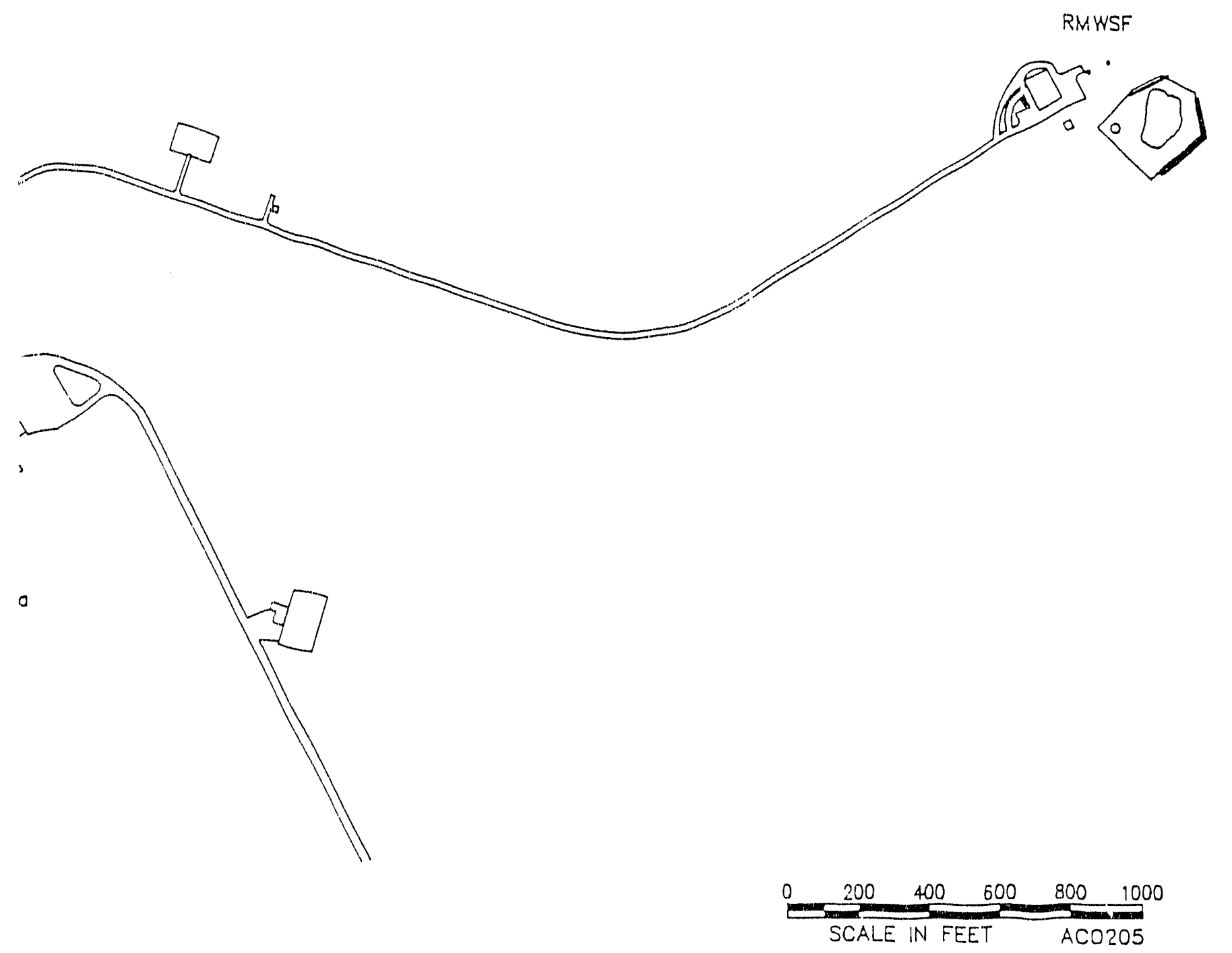

$$
11-16-90
$$




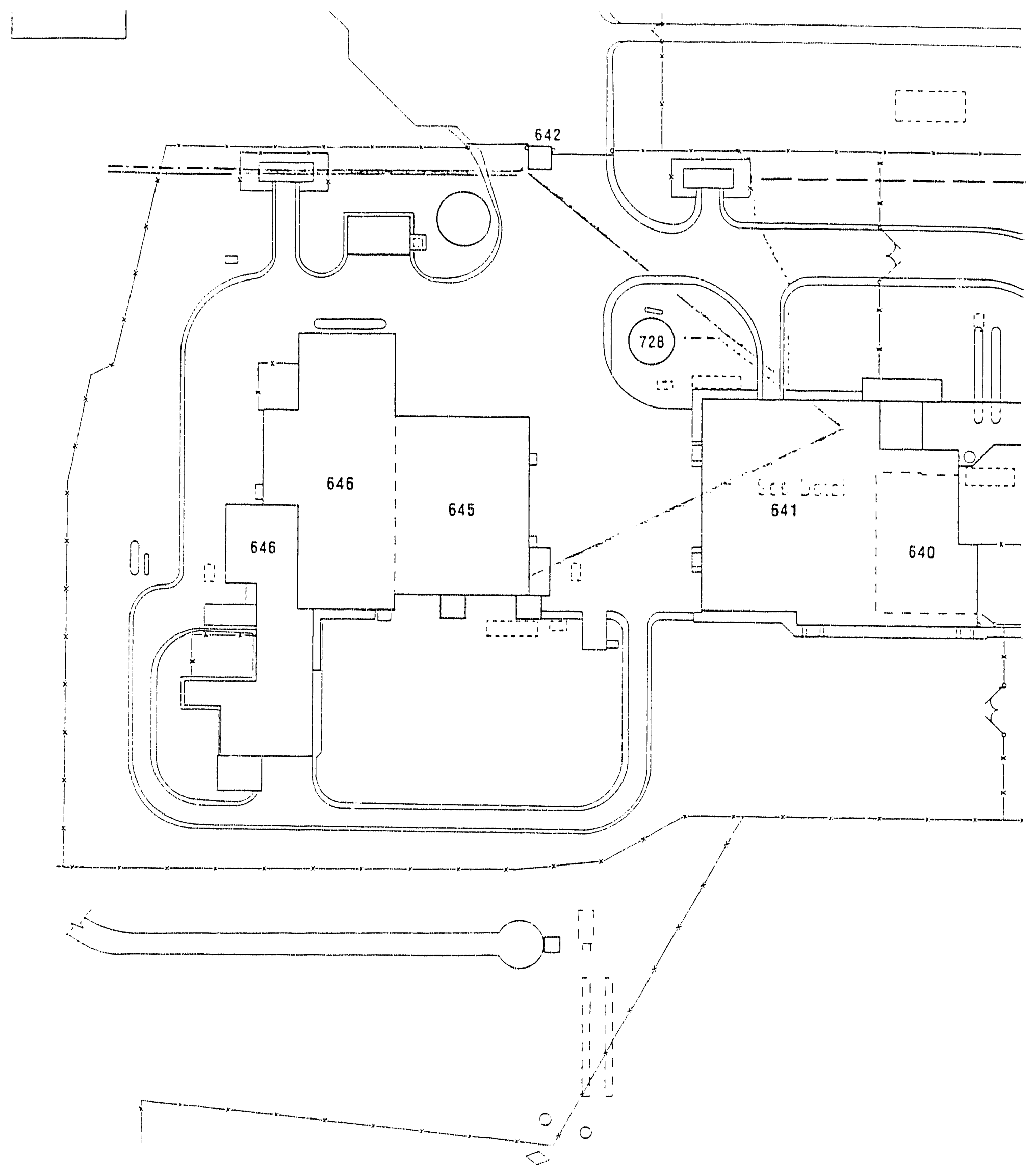

Figure 5. WRRTF telccommunications lines. 

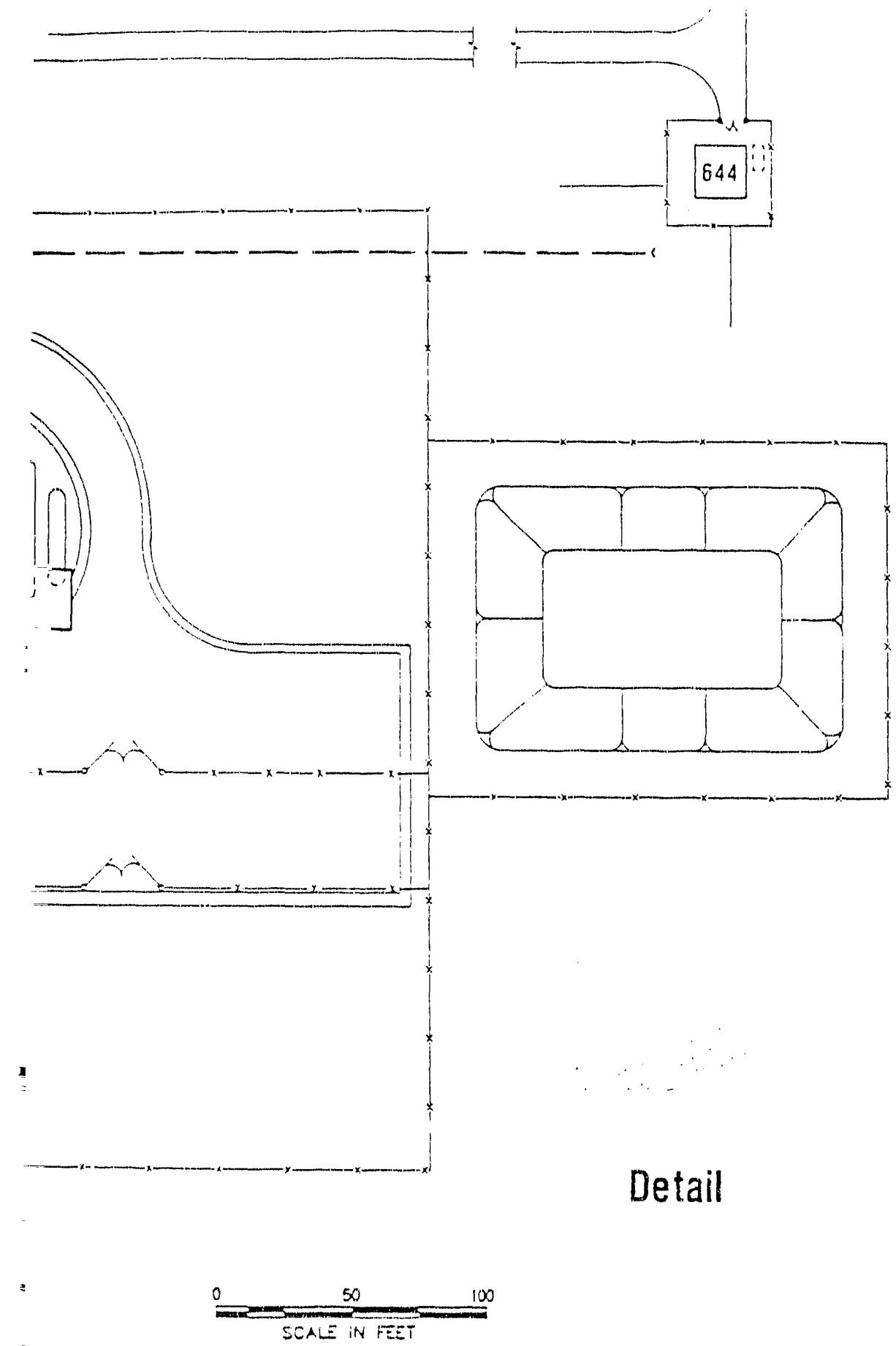

Concrete-Encased Conduit

-... Overhead Telephone Cable

-... Inderground Telephone Cable

in conduit

- - Overhead Alarm Cable

... Underground Alarm Cable

in conduit

... .... Overhead Control Cable

- Underground Contral Cáble

- Poles

Site Characterúcictics 


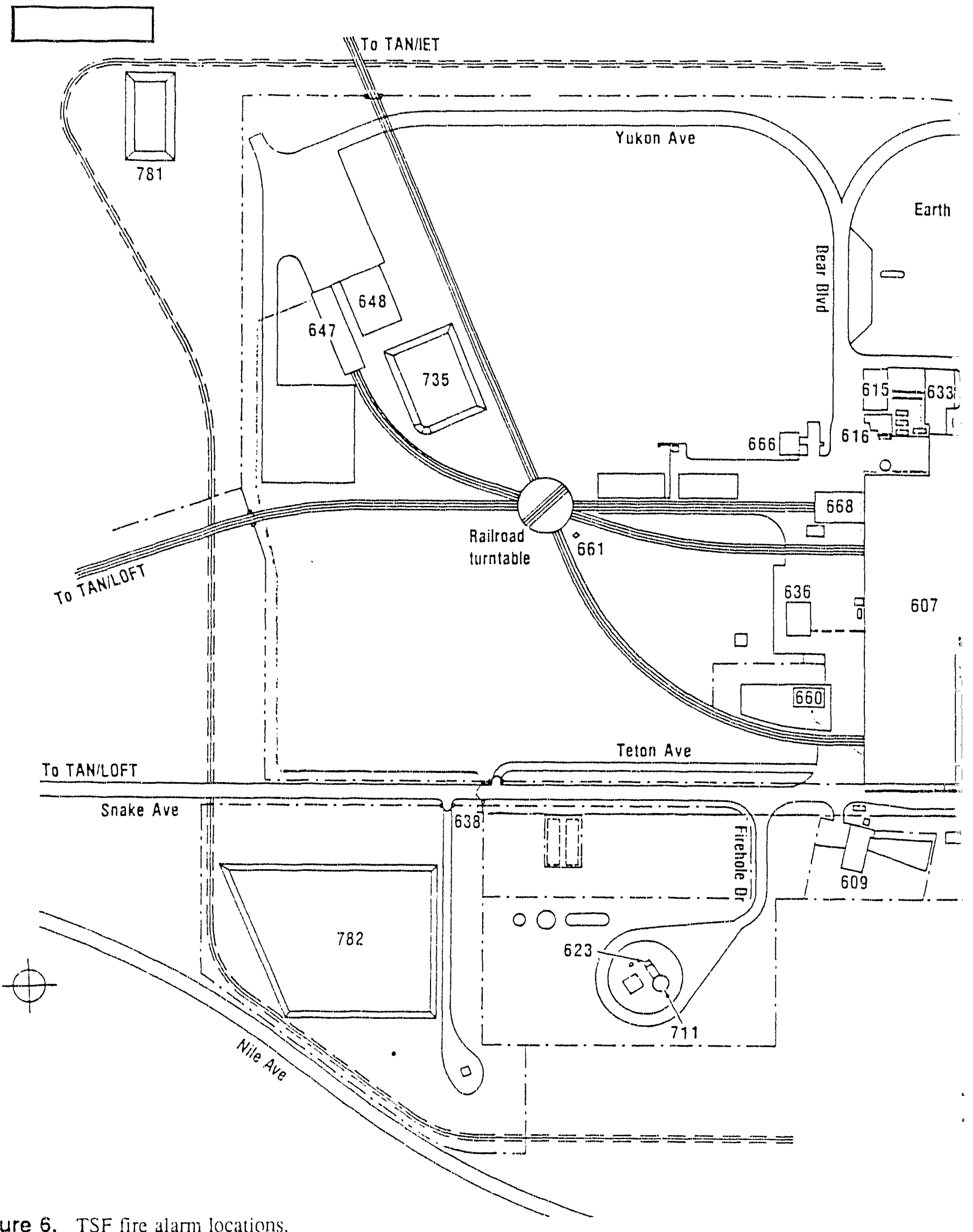

Figure 6. TSF fire alarm locations. 


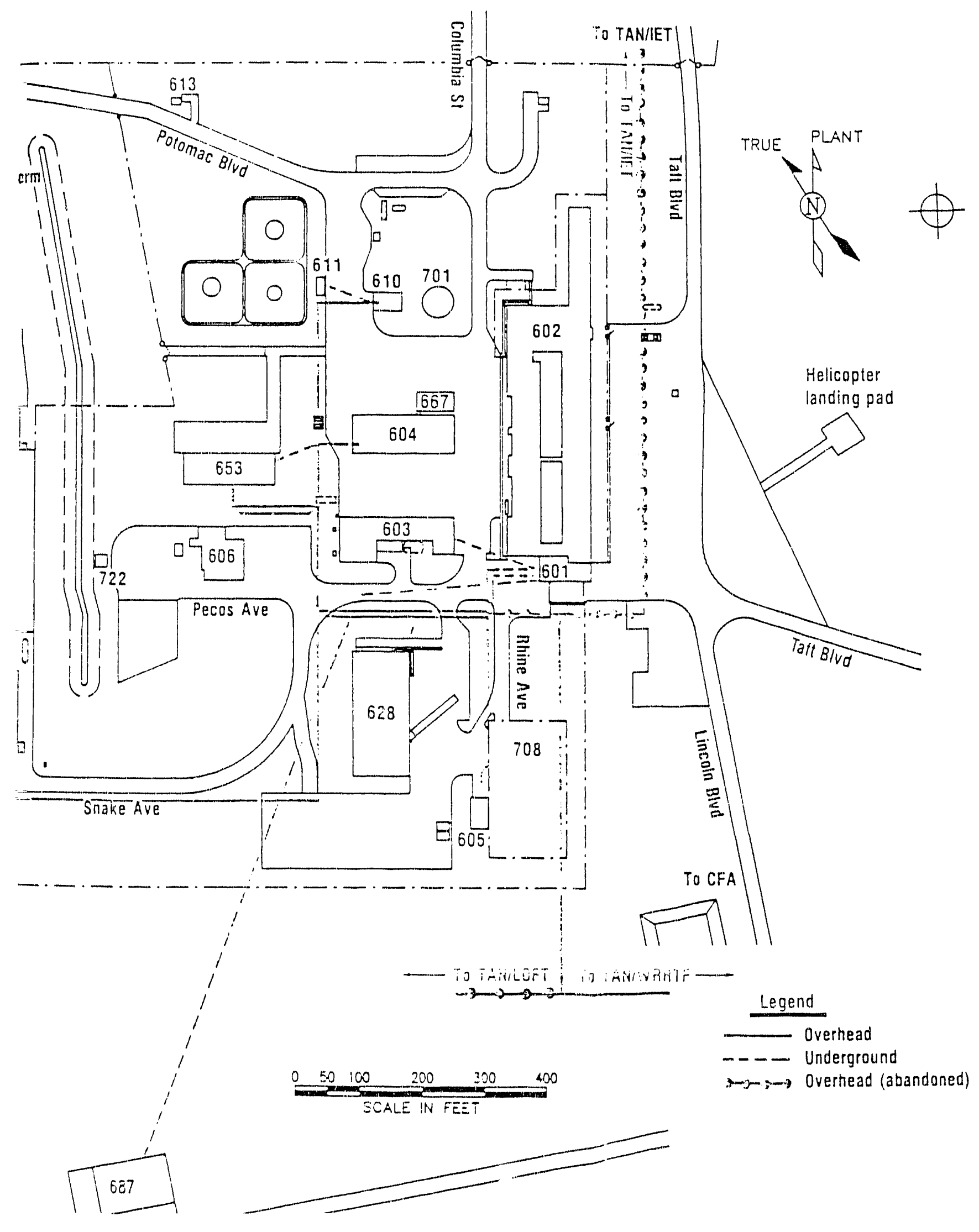

Site Characteristics 


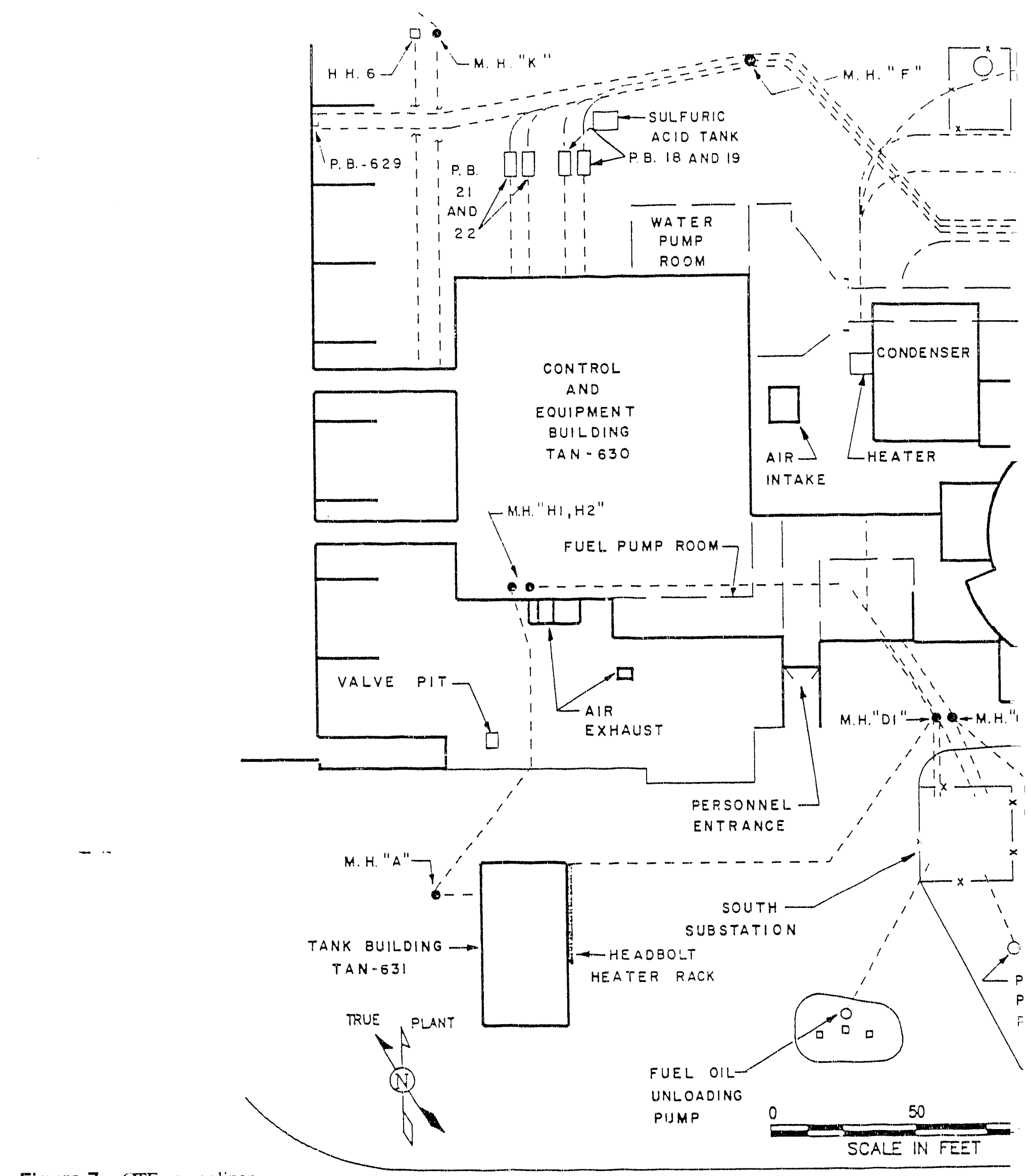

Figure 7. CTF power lines. 


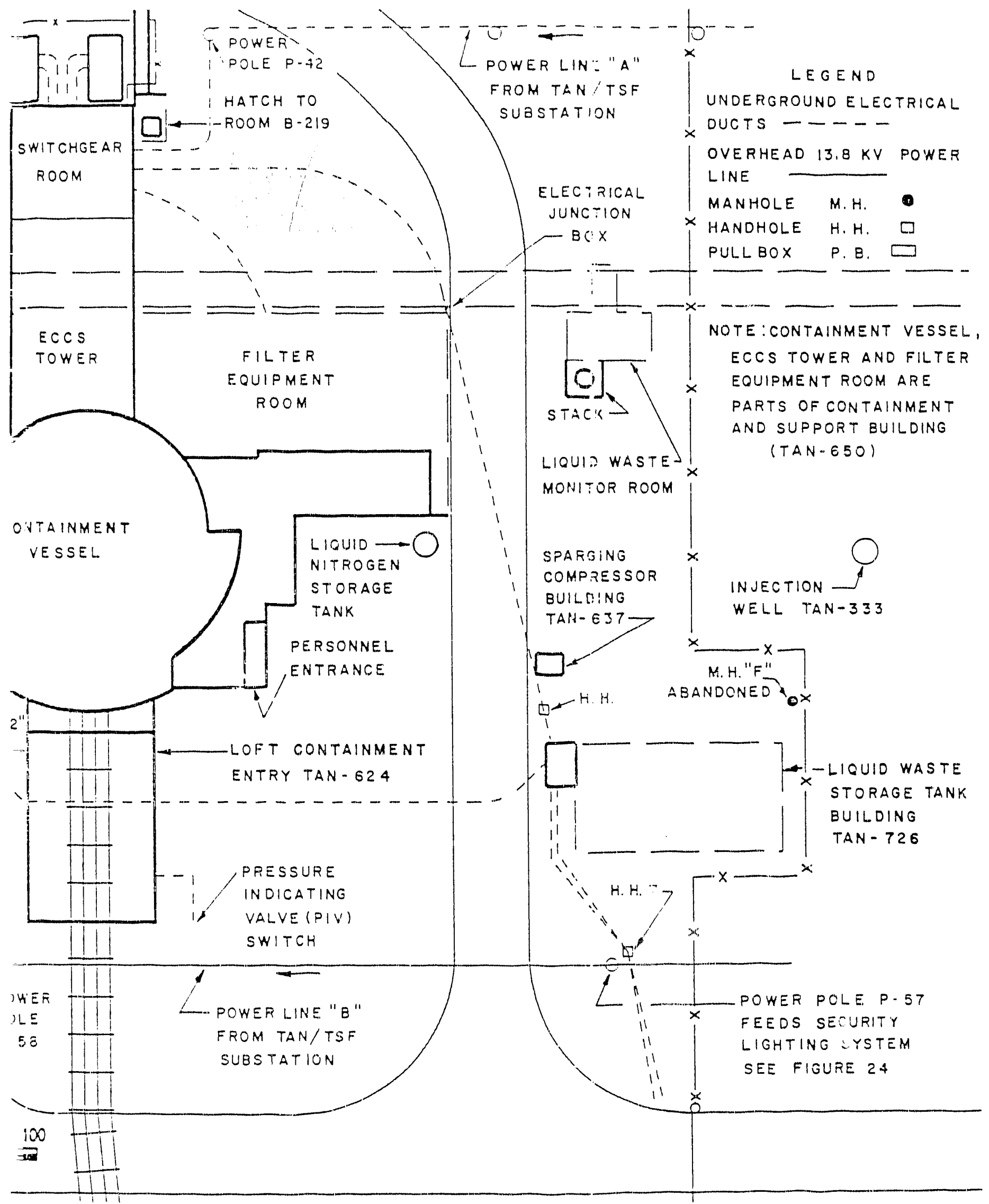



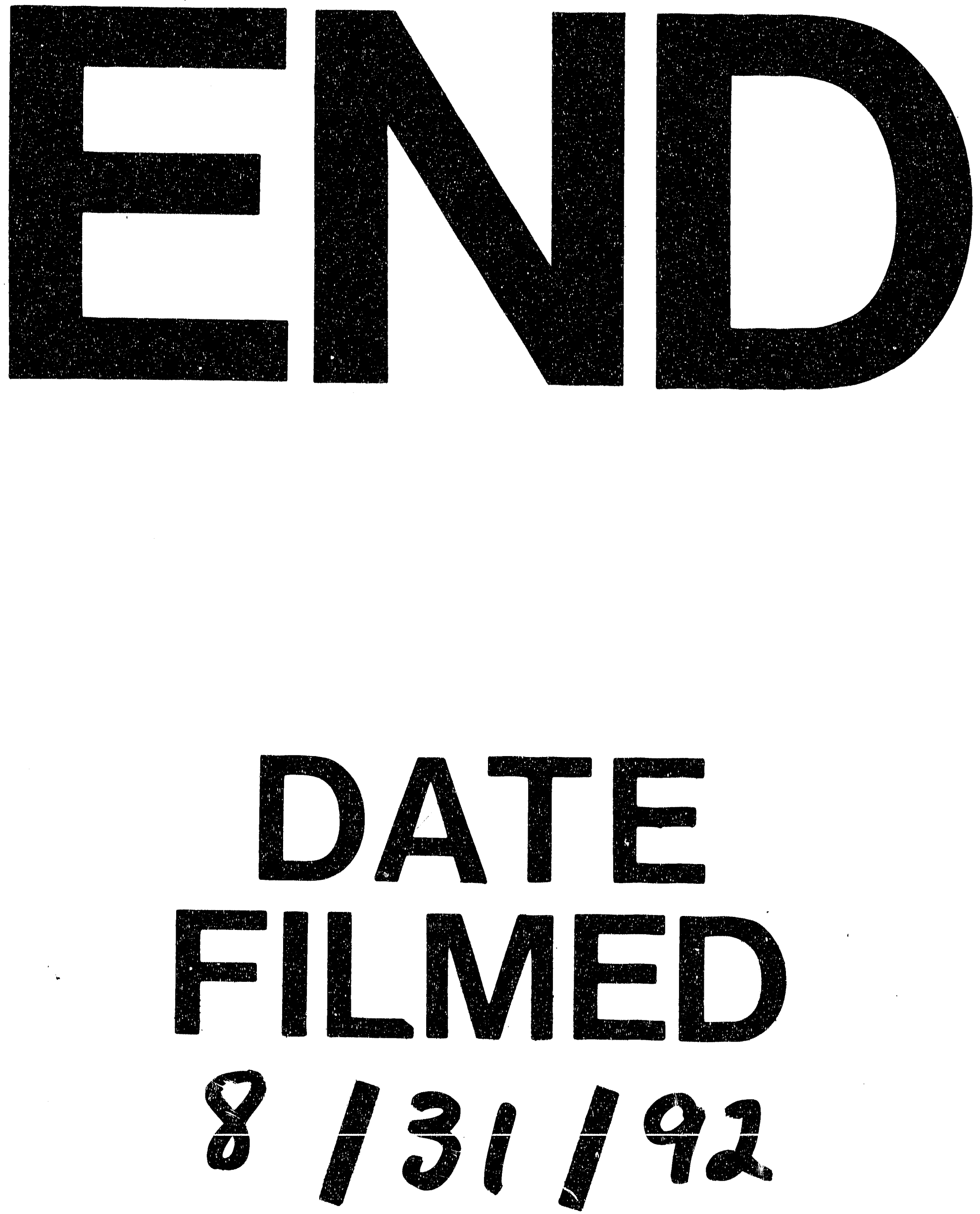


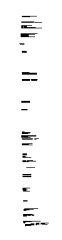

